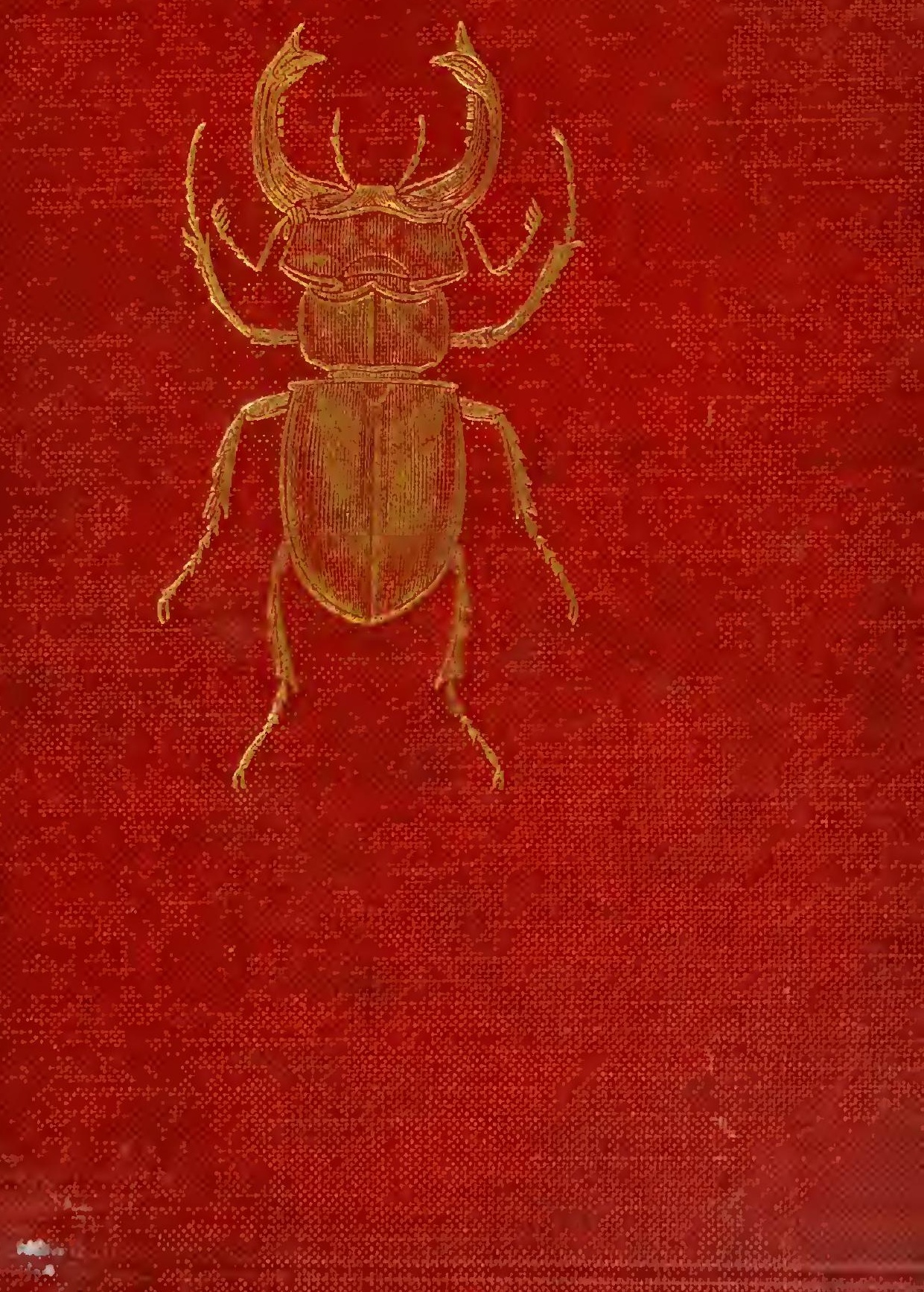



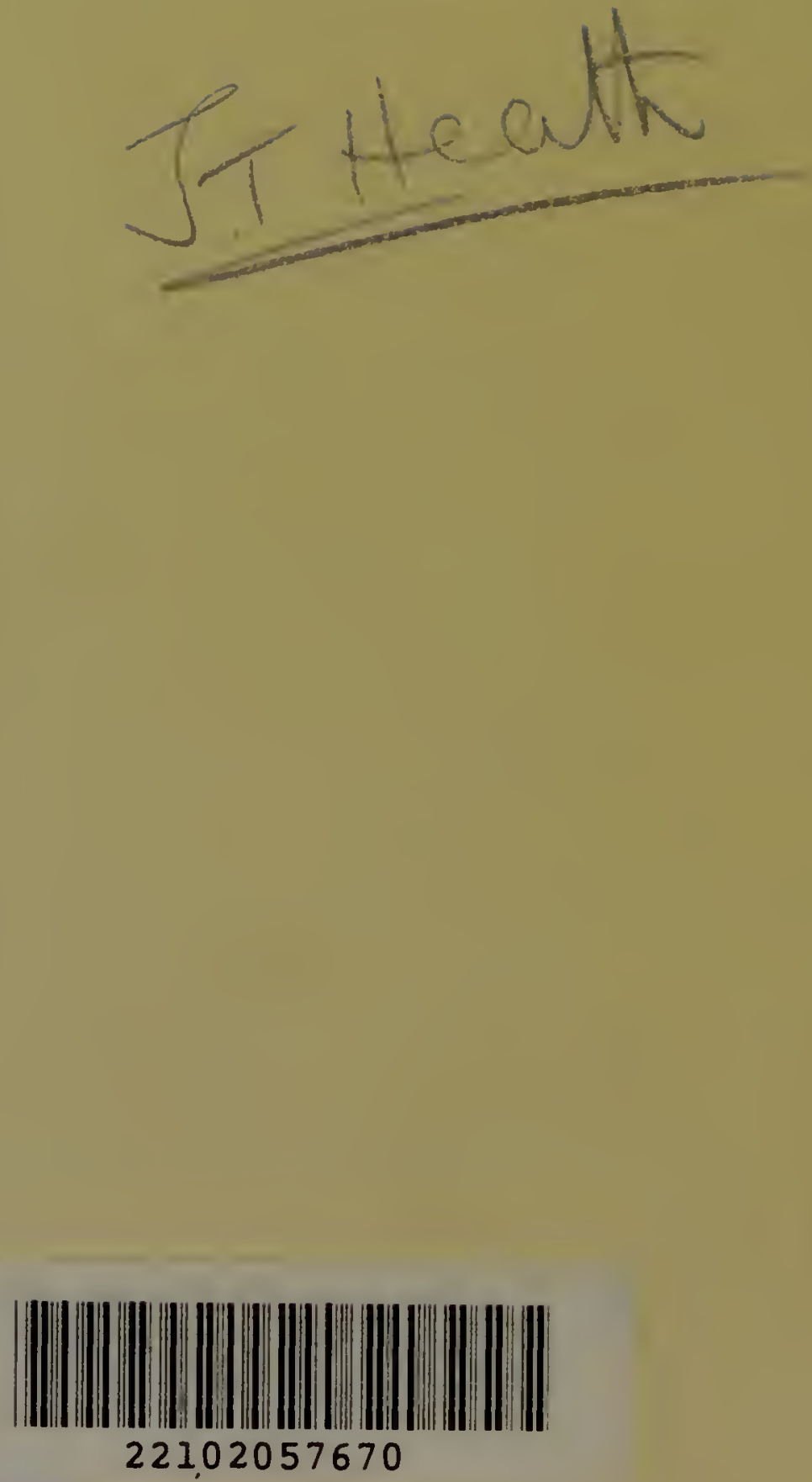

THE YOUNG

BEETLE-COLLECTOR'S HANDBOOK 


\section{OPINIONS OF THE PRESS.}

"For a very moderate price this handbook furnishes the beginner with a series of hints how to catch and kill beetles for his collection, and how to identify them when captured and killed. We can recommend the commencing naturalist to consider the beetle and its ways, and to buy this handbook by reason of its clearness of description."

Daily Chronicle.

"The portion of the book modestly termed the 'Introduction' is a valuable and thoroughly practical series of articles upon the structure of beetles, their development, habits of beetles, and how to catch them and kill them, arrangement of the collection, etc. It is written so clearly that the beginner could have no difficulty in identifying and classifying his finds. Over 500 of the species described are beautifully figured and coloured, the illustrations greatly enhancing the value of a handbook that can be heartily recommended to all naturalists." - Liverpool Post.

"We have seen no better book for the young beetle-collector than this. The plates are beautifully coloured."-Joumal of Microscopy.

"A very attractive and useful feature of the work is represented by twenty coloured plates, comprising over five hundred really good presentments of different kinds of beetles." - Knowledge.

"The plates arc worth the cost of the work."-Nature.

"Will be very uscful to schoolboys and residents in the country who arc inclined to begin to collect bectlcs."-Entomologist.

"This little volume is well bound and well printed, of a convenient size, and may be safely recommended to the notice of those young collcctors who are in want of a book that is not burdened with a great many hints on collecting." -Nature Notes.

LONDON : SWAN SONNENSCHEIN \& CO., LIM. 
This book is now published by

Messrs. George Allen \& Company, Ltd.

\author{
RUSKIN HOUSE, \\ tt ct t5, RATHBONE PLACE, \\ (IXIORL STREET, LONDON, IW.
}

to whom all orders should be sent. 



\title{
THE YOUNG
}

\section{BEETLE-COLLECTOR'S HANDBO0K}

BY

\author{
DR. E. HOFMANN
}

CURATOR OF THE ROYAL NATURAL HISTORY MUSEUM AT STUTTGART

waitb an Fntroouction

BY

W. $E G M O N T K I R B Y, M . D$.

JOINT AUTHOR OF "BRITISH AND EUROPEAN BUTTERELIES AND MOTHS"

“BEETLES, BUTTERFLies, MOTHS, AND OTHER INSEOTS," ETO.

ILLUSTRATED BY

TWENTY COLOURED PLATES, COMPRISING OVER 500 FIGURES

LONDON

SWAN SONNENSCHEIN \& Co., IIM. 


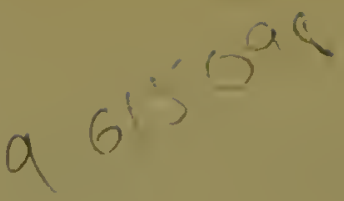

First Euition + . . May, 1897.

Second Edition * * . . . Maj, 1902.

THIRD EDITION . . . . Oct., 1908.

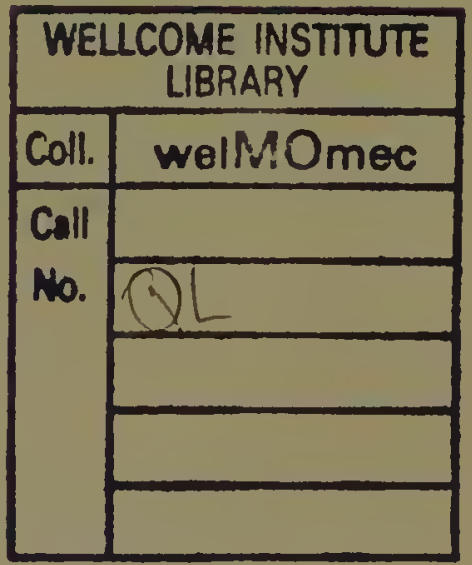




\section{CONTENTS}

\section{Structure}

DEVELOPMENT

Habits of Beetles, etc. .

How to Kill Beetles

How to Arrange the Collection

PENTAMERA-

Cicindelide (Tiger Beetles) .

Carabide (Carnivorous Ground Beetless)

Drtiscidas (Carnivorods Water Beetles)

Gyrinides (Whirligig Beetles)

HXDROPHILIDA

Staphylinider (Rote Bewtees) .

SILPHIDE

SCAPHIDIIDA .

Histerid

PhALACRIDE .

NITIDOLIDE

Trogositid E .

COLYDIIDE

CuCUJID

Cryptophagid de

LATHRIDIIDE .

MYCETOPHAGID $\mathbb{E}$

Dermestide (Bacon Beetles).

BYRRHIDA

PARNIDE

Heteroceride

Lucanida (Stag Beetles) 
PENTAMERA-continued.

Scarabaid w, ur Lamellicornes (Chafers) . . . 70

Coprophini (Dung Bettles) • • • . . 71

Melolonthini (Cockchafers) . $\quad$ • $\quad$. 78

RUTELINI .

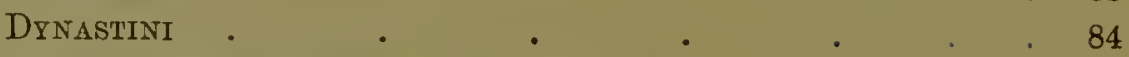

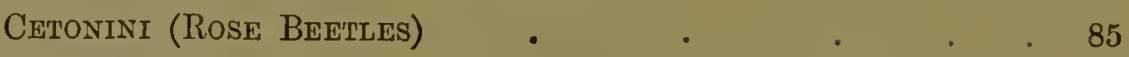

BUPRESTID •

EUCNEMID

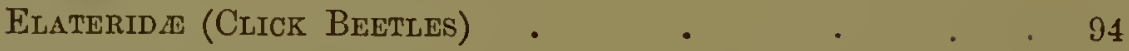

DASCILLID A .

MALACODERMIDAL

Clerid \&

LyMexylonid

Ptinide

HETEROMERA-

TENEBRIONID $A$

PYTHIDAS .

MELANDRYIDE

LAGRIIDAE

PYRochroId $\sqrt{2}$

MoRDELLID A .

RHIPIDOPHORID心

CANTHARID

CEDEMIERIDAE .

TETRAMERA-

CURCULIONidFs (WeEvils)

SCOLYTIDA (BOSTRYCHIDA)

ANTHRIBID .

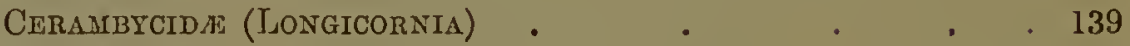

BRUCHIDE

Chrysomelid

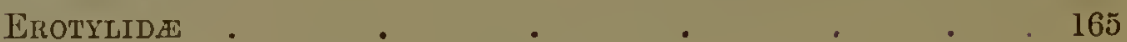

TRIMERA-

Coccinellida (Lady Birds) • , . . . 166

Pselaphides 


\section{INTRODUCTION}

STRUCTURE, \&C.

The Coleoptera, or Beetles, form the largest of all the Orders of Insects, numbering, as is estimated, about 130,000 specics, whilst the total number of insects known is about 300,000 . In this country we have over 3,000 species, which is about one-fourth of the British insect fauna.

Beetles are distinguished from other insects by having a pair of hard or leathery wing-cases, or elytra, which cover the true wings, which are membranous. The elytra generally meet in a straight line down the back, known as the suture.

I'he body of a beetle is divided into head, thorax, and abdomen.

The head is frce from the thorax, and only slightly narrowed behind. It is broader laterally than vertically, and is often prolonged into a proboscis, or trunk (as in the Weevils). The top of the head betwcen the eyes, above, is called the vertex, and 
that behind the eyes, the oceiput; whilst the part before the vertex is called the front, or clypeus.

'The head is furnished with eyes, antennæ, or feelers, and mouth organs.

The eyes are composed of a number of small facets, regularly arranged in a network, and eaeh of these faeets may be regarded as a separate eye. The eyes are plaeed on the sides of the head, and are generally large and prominent. In some beetles they are nearly divided into two by a process of the side of the head, whilst in some (ehiefly water beetles) they are eompletely divided, so that the beetles have apparently four eyes. In addition to the true eyes, some beetles have two small simple eyes, or ocelli, on the top of the head.

The antennæ are situated near the eyes, and have usually eleven joints. Antennæ which taper gradually to the end are called setiform (bristle-like); those which are uniform in thickness throughout are filiform (thread-like); if composed of a number of rounded joints, moniliform (bead-like); if with triangular elevations, dentated (toothed); and if with long processes on the joints, pectinated; if the joints become stouter towards the extremity, clubbed; and if the thickening is abrupt, capitate. In addition, the antennæ may be flattened, and, in some species, they end in a number of long, flat proeesses, and are fan-lilie (as in the cockehafers). Thus the antenna 
vary much in form and structure, and are consequently of use in classifying the insects.

The mouth organs are situated beneath the head, and are used to seize, and divide, the food. They consist of the labrum, or upper lip; the labium, or lower lip; mandibles, or upper jaws, which are hard and sharp, and often very large (as in the Stag Beetle); and maxillæ, or lower jaws. Two jointed organs, called the labial palpi, are attached to the labium, and two similar organs, the maxillary palpi, belong to the maxillæ.

The thorax is the part lying between the head and abdomen. It carries the legs and wings, and is divided into three principal portions-the pro-, meso-, and meta-thorax. The upper portion of the thorax is divided into pro-, meso-, and meta-notum, and the under surface is divided into pro-, meso-, and meta-sternum. The pronotum is the broad part seen above in front of the elytra; and behind it, and inserted between the base of the elytra, is a smali triangular plate, belonging to the meso-notum, called the scutellum. Each segment of the sternum bears a pair of legs.

Each of the legs consist of five parts-the coxa, or hinge-plate; the trochanter (a small joint between the coxa and femur); the femur, or thigh; the tibia, or shank; and the tarsus, or foot, which has normally five joints, the last bearing a pair of claws. 
The elytra, or wing-eases, are attaehed to the mesonotum, and, in most beetles, overlap the whole of the abdomen. They may be pitted or punetured, ridged or earinated, and are frequently spotted or striped, and sometimes hairy. Under the elytra are the true wings (springing from the meta-notum), whieh are folded when not in use. The wings alone are used in flight, the elytra being raised to allow them to have full play. In some beetles the true wings are quite wanting, whilst a few are completely apterous, having neither elytra nor wings.

The abdomen eonsists generally of nine rings, or segments, overlapping one another in a teleseopic manner, so as to allow of free movement. It is usually broad at the base, and somewhat flattened. On the sides is a row of spiraeles, or breathing-holes, situated between the segments of the thorax and abdomen.

\section{DEVELOPMENT.}

The males and females of beetles are often very unlike.

The females lay eggs, usually seleeting a plaee where the young larvæ will at onee find food for their sustenanee; thus some beetles form little pellets. of dung to eontain the eggs, and serve as food for the larvæ; and others roll up leaves, whieh proteet. 
the eggs, and afterwards the young. From the eggs emerge the larvæ, or grubs, which are elongated creatures, with a distinct, though sometimes small, horny head, bearing two very short antennæ, composed only of a few joints. They are either destitute of cyes, or liave only minute ocelli. The mouth organs of larvæ resemble those of the beetles, and the body (including the head) is composed of thirteen segments. As in the perfect insect, the number of spiracles is nine. The larvæ do not possess wings, and many of them are legless; most of them are, however, provided with three pairs of legs-a pair on the second, third, and fourth segments respectivelywhich are the thoracic segments. The legs of the larvæ are usually much smaller, and simpler, than those of the perfect insects, and some have a single proleg at the caudal extremity. On the dorsum there are often small plates, or tubercles. The body is soft and maggot-like in some, as in the Curculionide, or Weevils; in others, there are flat, chitinous plates; whilst others again are wholly chitinous, likie the perfect insects.

The larvæ of the Melolonthini, or Cockchafers, are short, curved creatures, of a yellowish-white colour.

The time required for the full development of larva is very variable, but all moult several times during their growth. Whilst the Chrysomelide pass through their metamorphoses in a few weeks, some bectles, 
such as various Longicornia and Melolonthini, require three or more years. When the larvæ have attained full growth they moult once more, and become pupæ.

The pupa generally casts off the larval skin, but in many species remains lying in it. The pupa inay be enclosed in a cocoon, or suspended by the caudal extremity, as in the Chrysomelidae and Coccinellida; or it may rest on the ground, or under the bark of trees; whilst others are subterranean. The pupæ are comparatively soft, and have partially-developed elytra, wings, and legs; but thcse are all enclosed in separate shcaths, and they are incapable of movement, beyond bcing able slightly to move the abdomen: they do not take food. After some time they change colour, throw off a membranous skin, and appear as beetles.

The bectle is at first soft like the pupa, and is usually ncarly colourless; but it hardens after a short time, and the elytra and wings assume their proper proportions and permanent positions. If the larra has bcen insufficiently nourished, the beetle will be small, and if the developing pupa has becn disturbed or kept too dry, a crippled condition is the result. 


\section{THE HABITS OF BEETLES, AND HOW TO CATCH THEM.}

The best months for collecting are May and June. The Carabida, or Ground Beetles, are common in gardens, and may often be seen running on roads; they may also frequently be met witl under stones, \&c. The Silphidae, or Carrion Beetles, live on any kind of refuse, and the Scarabceidce (Dung Beetles) fly in the evening, and settle on dung.

Many species may be obtained by sweeping the grass with a net, and also by beating or shaking trees and shrubs whilst an umbrella is held underneath.

The Longicornia rest on the bark of trees, and the Curculionidce (Weevils) and Scolytidce may be found on freshly-felled trees and wood piles; whilst the bark and rotten wood of diseased trees will well repay a close scrutiny. A large number of beetles will be found upon flowers, particularly on the Umbelliferce, whilst other's are only to be found upon the foodplant of the larva. A great many species fly by day, e.g. the Buprestidce, and may be cauglit with the net.

Many of the smaller beetles live under dead leaves or among moss at the foot of trees. This may be shaken over a sieve, and what passes through taken home and carefully examined on a large sheet of white 
paper. The banks of streams, ponds, and lakes are good localities, and many species are to be found in such places, especially under stones. The Water Beetles (Dytiscida, \&c.) live in ditches and ponds, and must be caught with a water-net. The largest captures may be expected when the water is high, as the collector will then be able to take home portions of plants from the brink and examine them at his leisure.

\section{HOW TO KILL BEETLES.}

There are various ways in which beetles may be killed. The simplest method of dealing with dark beetles, or those which are smooth and shining, is to drop them into a bottle of weak spirits of wine and water; but this is inadmissible for hairy species and for those which have a red colour. For these the best contrivance is the following: a wide-mouthed bottle is taken, and in it is inserted a bung, perforated to receive a glass tube closed with a cork. In the bottle are placed small pieces of blotting-paper moistened with a few drops of sulphuric ether. The reason for this arrangement is to prevent damaging the wing-cases by friction, and the better to benumb and kill the beetles. It is not good to use too much ether, lest the specimens be moistened and spoilt. Bottles are sometimes charged with cyanide of potassium; whilst some collectors use 
the young shoots and leaves of the laurel, gathered when quite dry and chopped fine.

The best way to kill beetles brought home alive, unless they are soft, finely pubeseent, or of delicate colouring, is to plunge them into boiling water; but this must be done rapidly, or the beetle will be softened and easily eome to piees.

Bectles killed with cyanide of potassium must not be left in the bottle long, and should soon be taken out and set; and those treated with boiling water should also be set immediately; but those killed with ether may generally be left till next day, as this substanee tends to keep them longer relaxed; whilst the speeimens in spirit will often keep in the bottle for weeks or months.

After it has been killed the beetle should be plaeed on blotting-paper, and a pin stuek through the right wing-ease. It is then transferred to a thick pieec of cork or turf eovered with paper, and the legs and antennæe are spread out with pins and propped in the position seen on the plates. The beetles will be dry in a day or two (soonest in lot weather), and ean then be transferred to the collection. 


\section{HOW TO ARRANGE THE COLLECTION, \&c.}

In arranging the collection it is best to commence by naming the species which we know, and then to put aside those belonging to casily distinguished groups, such as the Cicindelida, Carcibide, Melolonthini, Curculionida, and Longicornicu. If we do not know what family to refer a beetle to, we must count thc number of joints of the tarsi, and so find out which section each beetle belongs to.

Those which have five joints to all the tarsi belong to the Pentamerce, which includes the Cicindelider, Carcubidce, Dytiscide, Staphylinidee, Melolonthini, and many smaller families, in some of which the number of joints is not constant, as is the case exceptionally in all familics. Next pick out those which have five tarsal joints on the first and second pairs of legs, but only four on the posterior pair. These arc the Heteromerce, and include the Tenebrionida, Melandryide, Lagriide, Mordellidee, Cantharide, \&c. Then come those which have only four joints to all the tarsi - the Tetramera, to which belong the Curculionida, Longicornia, and Chrysomelida. Whilst the fourth scction, the Trimera, in which there are only apparently threc joints to all the tarsi, includes the Coccinellida and Pselaphide, \&c.

When the spccimens have been sorted into these 
four sections, it will be further necessary to identify the species by means of plates and descriptions.

It is best to arrange the species in the cabinet, or store boxes, in columns, and it is usual to keep three specimens of those of which several can be obtained. The name of the family and genus should be written on a small label at the head of the column, and the name of the species beneath.

The locality where each specimen was taken is best written on a small slip of paper, and pinned under the insect to which it belongs, or it may be placed below or beside it on a separate pin.

The drawers of an insect cabinet are made of wood, and should all be of the same size, so as to be interchangeable. There is a glass lid, and the bottom is lined with cork or turf, over which thin white paper is pasted.

To keep out mites a lump of camphor should be placed in the corner of the box or drawer, or a few grains of naphthaline may be substituted.

Of course the collection will increase most quickly at first, because everything will be new; but as it grows it will become more and more complete, as the rarer species are added to it; and in due course the energetic collector may expect to amass a very characteristic set of the coleopterous fauna of the neighbourhood in which be is living. 
NOTE.

Every species which is found in the British Isles is indicated by $a^{*}$. 


\section{BEETLES}

\section{SECTION I. PENTAMERA.}

(Beetles with five joints to the tarsi of all the legs.)

\section{Family I. CICINDELID平 (Tiger Beetles).}

Elongated beetles of a fine metallie eolour beneath. Head broad with prominent eyes, and long, slender antennæ and legs. They run quiekly, and fly in jerks for short distanees. They feed on other inseets, and are therefore useful. They are found in sandy places, where the larve lie in wait for their prey in holes in the ground.

Genus Cicindela, Limn.

* C. campestris, Linn., the Green Tiger Beetle (Plate I., Fig. 1). Everywhere common on sandy paths and grassy plaees. In the South of Europe numerous local varieties oeeur.

* C. hybrida, Linn., the Hybrid Tiger Beetle (Plate I., Fig. 2). This speeies is also eommon in sandy plaees, and varies loeally.

C. sylvicola, Dej., the Swiss Wood Tiger Beetle (Plate I., Fig. 3). Sinilar to the last speeies, but with the two shoulder spots always interrupted. It is found in Switzerland and Southern Germany, where it frequents sandy slopes in woods.

* C'. sylvatica, Linn., the Woorl Tiger Beetle (P'late I., Fig. 4). 
Coppery black above, and easily distinguishable from the last species. It is found in pine woods, running about on the sandy paths. It is the largest species found in Britain, and occurs, among other places, at Bournemouth.

* C. germanica, Linn., the Small Green Tiger Beetle (Plate I., Fig. 5). This is the smallest species found with us. It is found in fields and grassy places, and unlike the other species, which take to the wing when disturbed, this beetle seeks to escape by running and hiding among tufts of grass.

\section{FamLY II. CARABID\& (Carnivorous Ground Beetles).}

This is a large family, the members of which have long legs, run quickly, and are carnivorous in habits. Black is the most comnion colour among them. They lide under stones, moss, and bark, and are very useful, as they keep down the numbers of insects and their larva in woods, gardens, and fields. The larve of the ground beetles are just as useful as the beetles themselves; they live in similar places, and also in dung-heaps.

Genus Oxophron, Latr.

Body rounded, head retracted under the prothorax. In the males the first two tarsal joints of the front pair of legs are expanded.

O. limbatum, Fabr. (Plate I., Fig. 6). This species lives under stones on the sandy banks of streams. It is common on the Continent, but is not found with us. It may be caught at night with the lantern.

\section{Genus Blethisa, Bon.}

Thornx flat, nearly square, with a distinct border on the sides, and a deep groove near the hinder angles. Eyes only slightly prominent. The only species found in Britain is: 


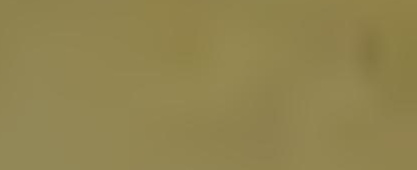

\section{.}



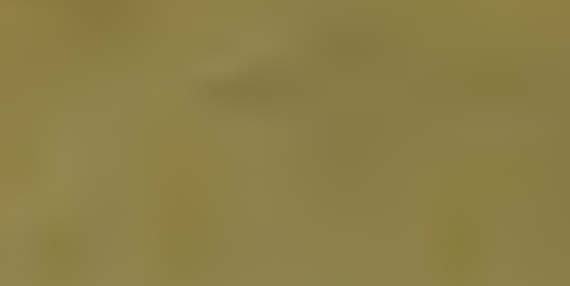

\section{titi}

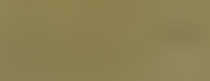

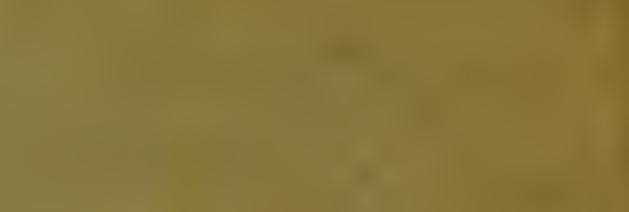 \\ $1+1$}

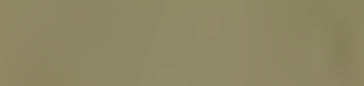
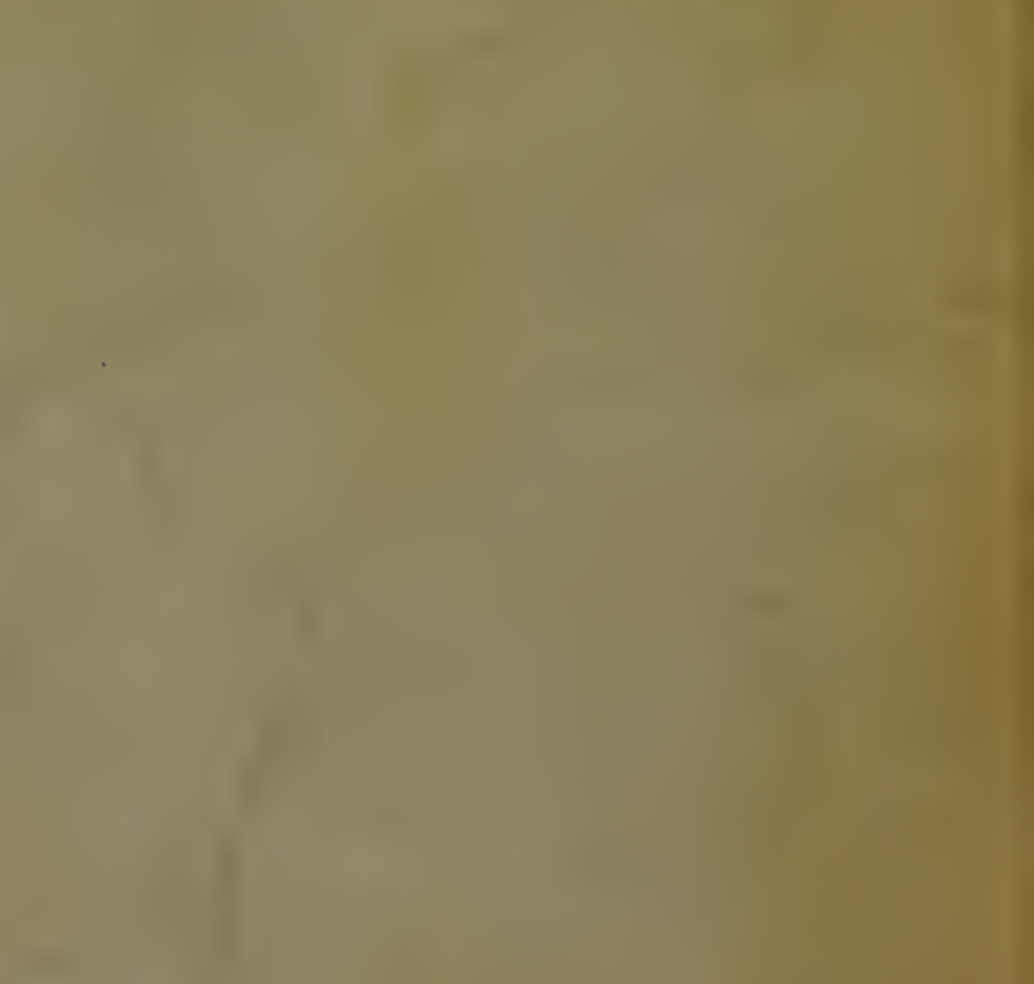

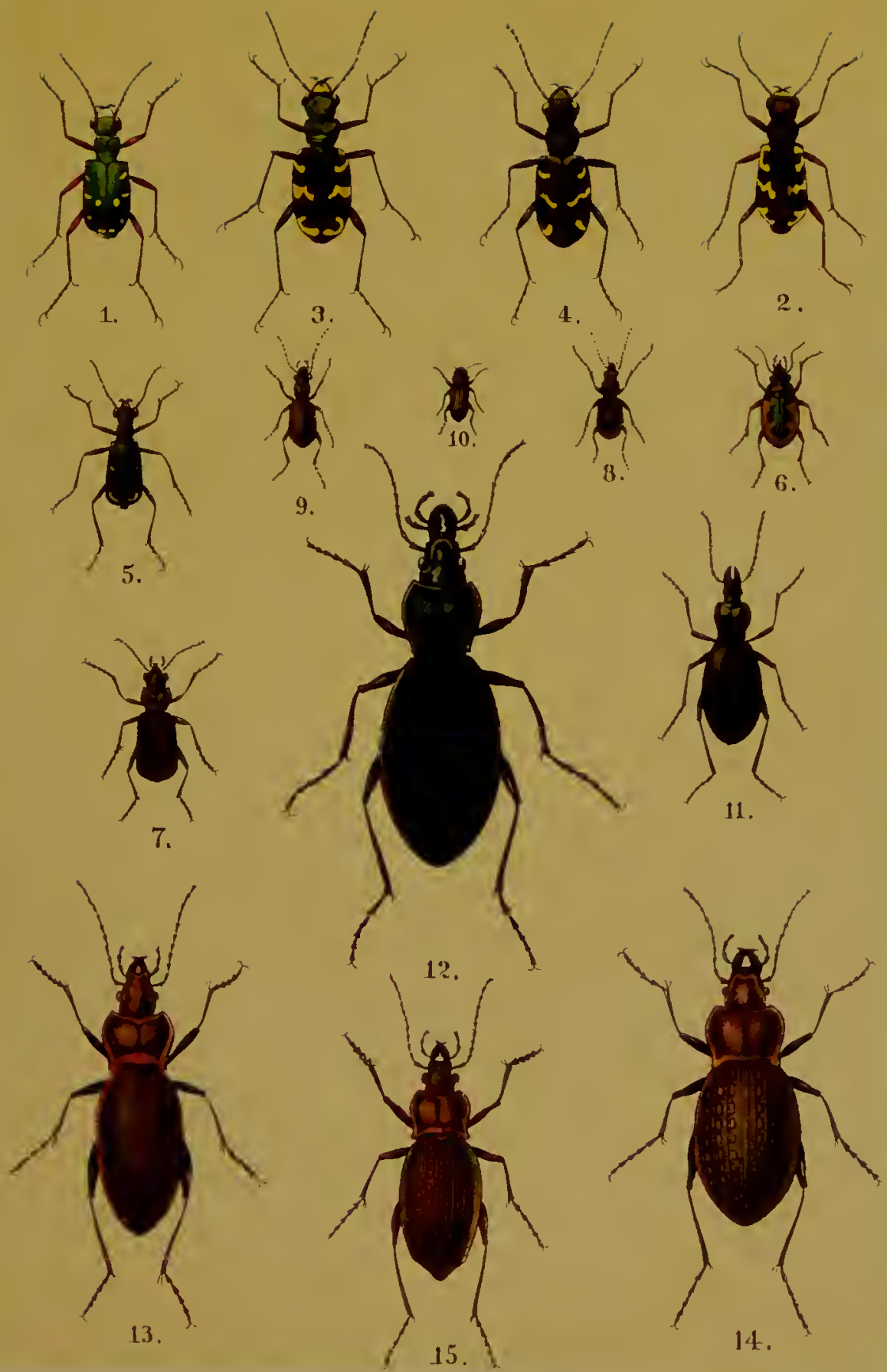

* B. multipunctata, Fabr. (Plate I., Fig. 7). This is loeal, and lives in damp meadows and on the slimy margins of ponds. It is also often found in large numbers in rotting herbage.

\section{Genus Elaphrus, Fabr.}

Small speeies with large, spherical, and very prominent eyes, and with eonspicuous eye-spots on the dull wing-eases. They are found in damp plaees, the banks of streams, \&c.

* E. cupreus, Duft. (Plate I., Fig. 8). This beetle has yellowish-brown tibire. It is eommon on the borders of ponds in the summer, and spends the winter under moss.

* E. uliginosus, Fabr. (Plate I., Fig. 9). Thorax broader than that of the last species, and indeed broader than the head. Tibir violet. Its habits are the same as those of the other speeies mentioned.

\section{Genus Notiophilus, Dum.}

Smooth, shining little beetles, with very large eyes. The thorax is twice as broad as it is long, and the abdomen is elongated.

* N. aquaticus, Linn. (Plate I., Fig. 10). This is a fairly eominon British speeies, being frequently met with from spring to autumn in damp places. There are four other species found in Britain, some of whieh prefer drier loealities, and may be found running over paths or flower-beds.

\section{Genus Cychrus, Fabr.}

These beetles have the body very eonvex; the elytra are twice as broad as the thorax, whieh is widest in the middle, and has a raised border. They live under stones and among damp grass.

* C. rostratus, Limn. (Plate I., Fig. 11). This inseet is found throughout Europe, including the British Isles, under stones, in woods, and in damp grass in the spring. 


\section{Genus Procrustes, Bon.}

Labrum with two eoneavities. Menturn with a broad, obtuse tooth in the middle. Legs long, with the first three joints of the front tarsi expanded in the males. Found in woods.

P. coricceus, Linn. (Plate I., Fig. 12). This is a large gronnd beetle, which is found in many plaees on the Continent, under stones and leaves in woods, and less frequently in gardens, but is not British.

\section{Genus Carabus, Linn. (True Ground Beetles).}

Most of the speeies are large and showy, and are remarkable for their bright metallie eolonrs and the very various seulpturing of the elytra. The third joint of the antennæ is eylinclical and longer than the rest. Abdomen oval. Front tarsi of the males with three or four expanded joints. They are most eommon in hilly clistriets.

* C. monilis, Fabr. (Plate I., Fig. 13). Elytra green, blue or eoppery. It is eommon with us, under stones and elods.

C. ulvichii, Germ. (Plate I., Fig. 14). Elytra very eonvex, larger than in the two next speeies. It is found in South Central Europe, where it passes the winter in tree-trunks and under moss.

* C. cancellatus, Illig. (Plate I., Fïg. 15). Antennæ with the basal joint red. Wing-eases reddish or bronze-coloured, with three longitudinal ridges and long granulations. It is found in May, but is doubtfully British.

* C. granulatus, Linn. (Plate II., Fig. 1). This speeies is similar to the last, but usnally smaller and with black antemne. It is eommon, and is found in swampy places.

C. auratus, Linn., the Gold Beetle (Plate II., Fig. 2). The spaces between the green longitudinal ridges of the elytra 



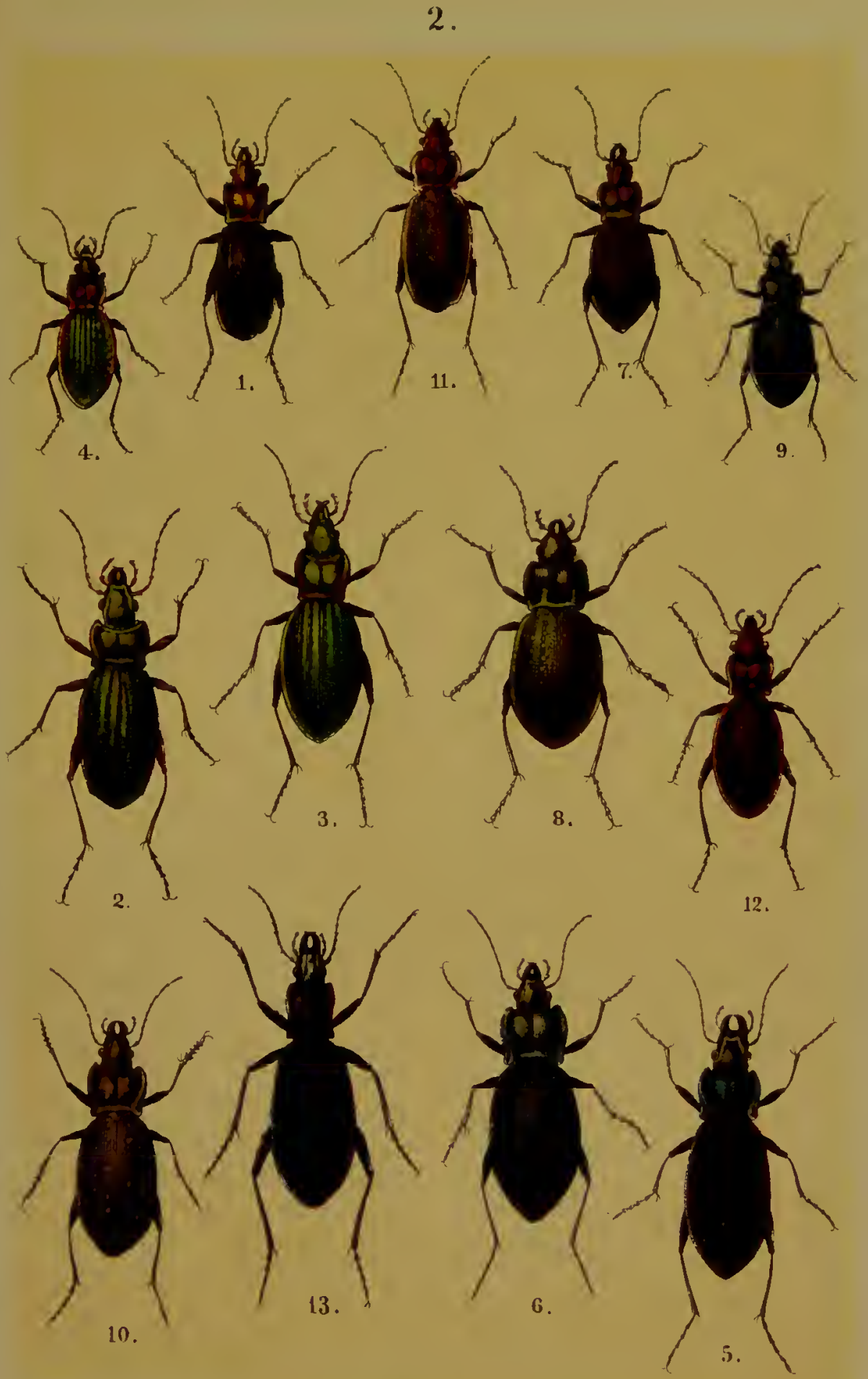



are almost smooth. This handsome species is common in many places on the Continent, notably in France, Western Germany, and Switzerland, but when found in Britain has probably been introduced.

C. auronitens, Fabr. (Plate II., Fig. 3). The grooves between the black longitudinal ridges of this species are finely corrugated, and the first joint of the antennæ is red. The thorax generally has a golden lustre. It is not found with us, but is. common in hilly districts in many parts of the Continent, where it may frequently be taken in rotten stems of dead trees.

* C. nitens, Linn. (Plate II., Fig. 4). This pretty species: is the smallest of the Carabidce found with us. It is of a brilliant green, with the edges shining coppery-red, and three black longitudinal ridges on each of the elytra. It is not. very common, but may be found on moors and mosses.

* C. violaceus, Linn. (Plate II., Fig. 5). The wing-cases of this beetle are dull blue-black, edged with bright blue or violet. It is common under moss or stones in woods.

* C. glabratus, Payk. (Plate II., Fig. 6). The wing-cases are strongly convex, with dull blnish borders. It is found in fields near woods.

* C. arvensis, Fabr. (Plate II., Fig. 7). Wing-cases copperyred, greenish, violet, or almost black, with raised granules. It frequents woods and sandy fields.

* C. nemoralis, Mïll. (Plate II., Fig. 8). Pronotum purplish, elytra coppery, with three rows of metallic punctures. It is common everywhere, near woods, under moss and stones, \&c. This spccies, monilis, and violaceus are about the commonest species of the genus fonnd in Britain, and may often be fonnd dead on the roads, a little ont of London, having been trodden upon during their nocturnal liambles. 
C. convexus, Fabr. (I'late II., Fig. 9). This species is almost black, but may be distinguished from glabratus by its snraller size. It is found in wooded slopes on the Continent, but is local, and it does not appear to be found with us.

C. hortensis, Linn. (Plate II., Fig. 10). This species has three rows of shining golden punctures on the wing-cases. It occurs in some parts of the Continent.

C. sylvestris, Fabr. (Plate II., Fig. 11). This species is of the same size and colour as arvensis, but with rows of spots instead of granules on the elytra. It is found in lilly places on the Continent.

C. irregularis, Fabr. (Plate II., Fig. 12). Wing-cases smooth, except for three rows of deep punctures. It is found at a high elevation, in the rotten stumps of trees, on the Continent.

* C. intricatus, Linn. (Plate II., Fig. 13). This is an elongated beetle with bluish-black corrugated elytra. This species, unlike those immediately preceding, is a native of Britain.

C. nodulosus, Creutz. (Plate III., Fig. 1). This easily distinguished species is found in some parts of Germany, Eastern France, and South Russia. It frequents wet, swampy places in woods and damp moors, and will even enter shallow water.

Genus Calosoma, Weber.

This genus is distinguished by the size and by the square or oblong form of the elytra. The labrum is emarginate, and the mandibles are transversely striated on the upper surface. They live in woods, and prey upon other insects.

C. sycophanta, Linn. (Plate III., Fig. 2). This is the largest of the Carabida occurring in the British Isles. Specimens are usually found on the coast, and are believed by somc authors to have flown across from France. Its favourite 


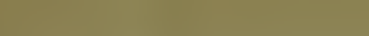

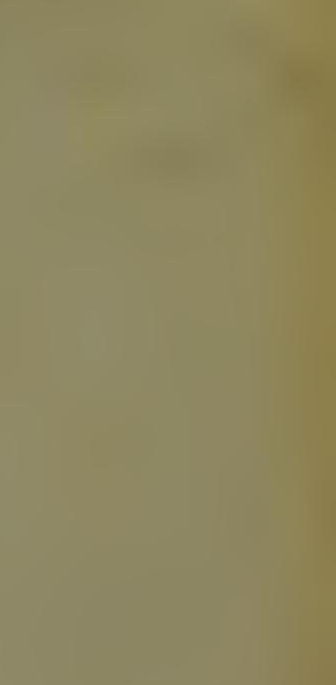



3.
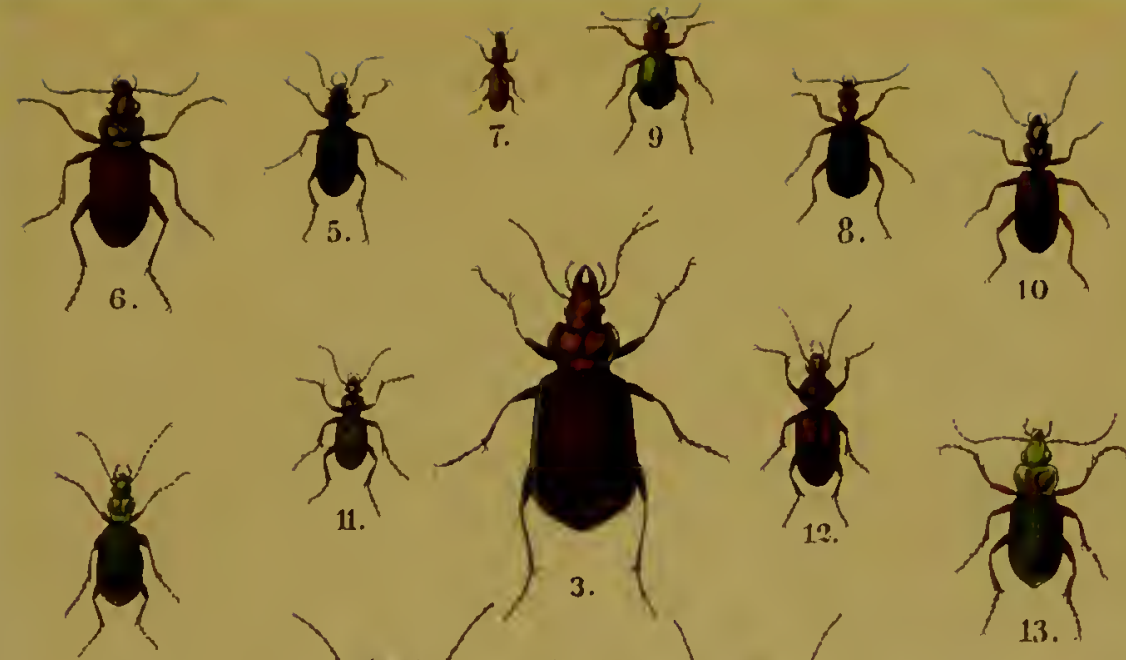

11.

$\int_{1}^{15}$

(15)

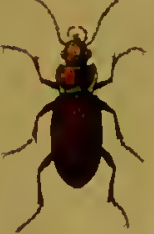

2
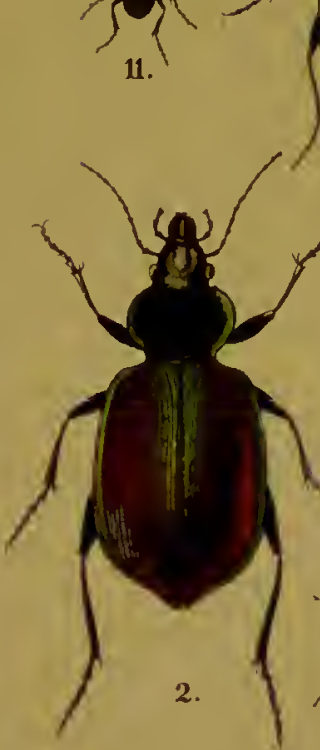

$\rightarrow \int_{12}$
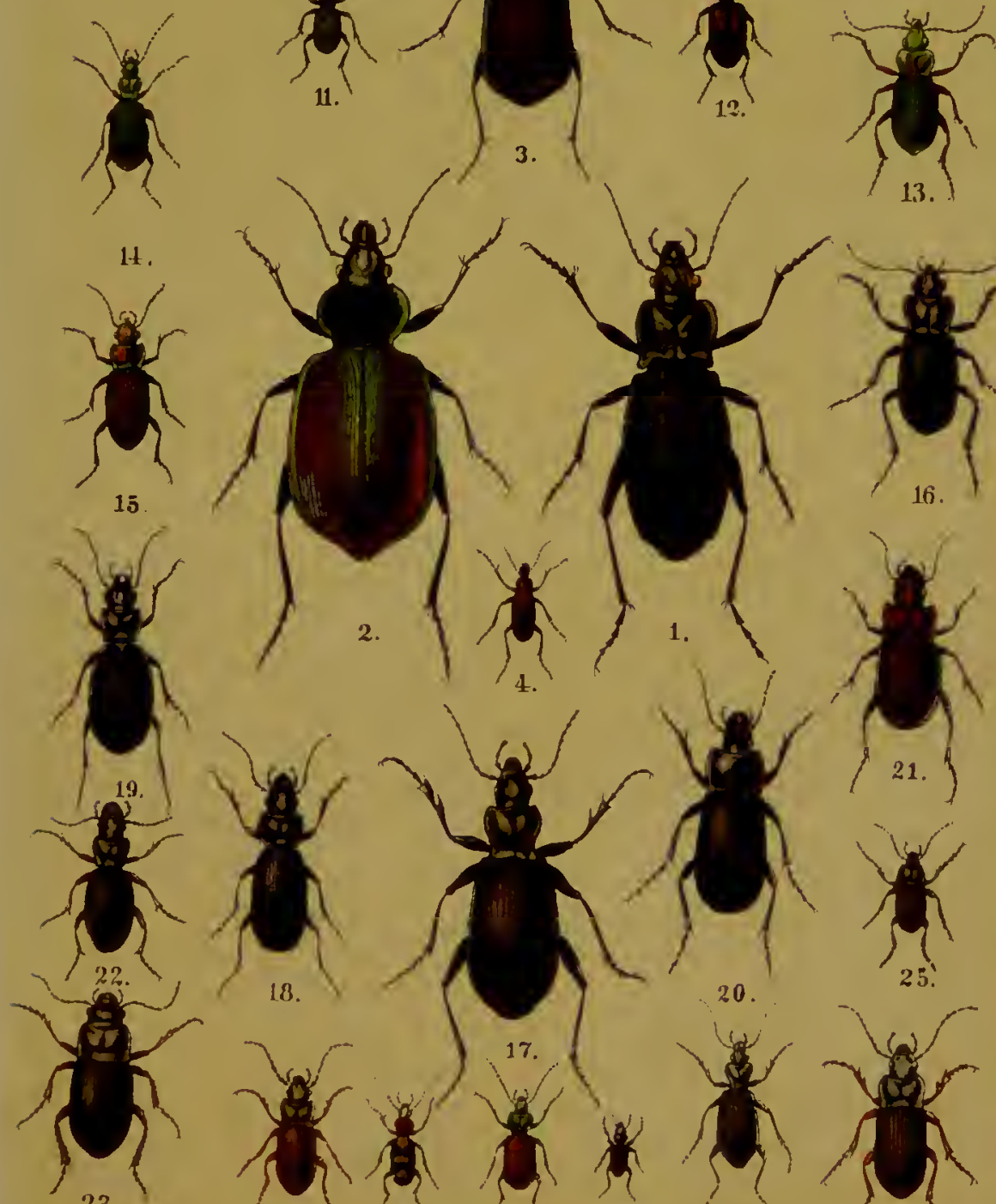

23.
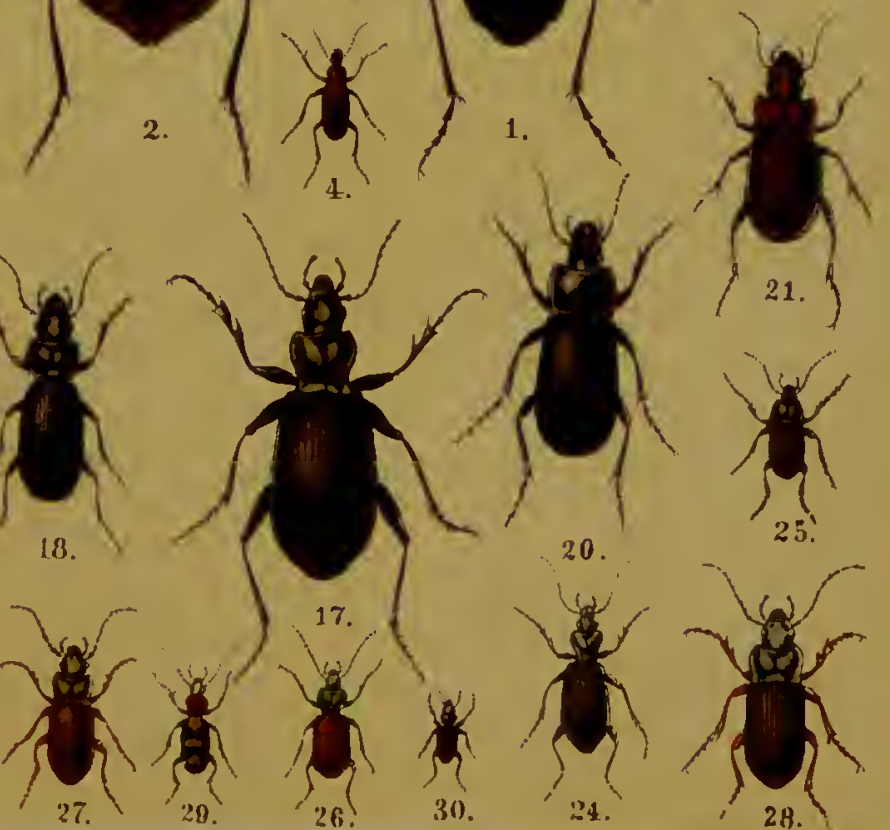

1.
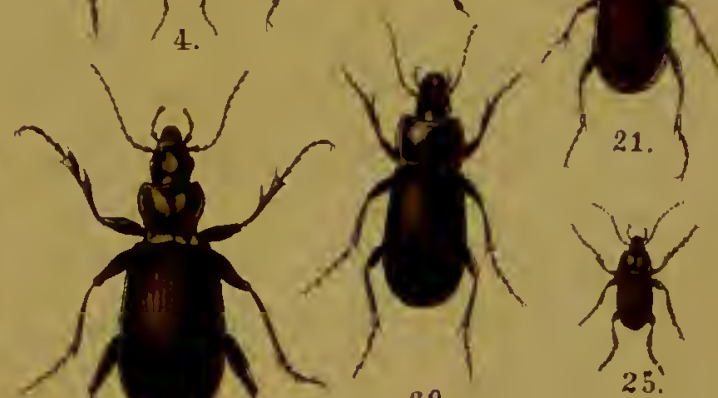

25 .
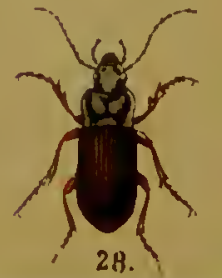

haunts are pine and oak woods. It will elimb up trees in seareh of larva and pupa, whiel it feeds upon, and is eommon on the Continent in the nests of the processionary eaterpillars.

* C. inquisitor, Lim. (Plate III., Fig. 3). This speeies is dark coppery-brown-oceasionally blackish or bluish. It is much eommoner with us than the last speeies, and may be found on fruit trees and in oak woods.

\section{Genus Leistus, Froehl.}

Labrum transverse, rounded in front; maxillæe toothed on the outer border with long movable bristles. The first joint of the antennæ is by far the largest. They are of moderate size, and are found in mountainous distriets under stones.

* L. ferrugineus, Linn. (Plate III., Fig. 4). Elytra and legs brown. It is found in damp places.

* L. spinibarbis, Fabr. (Plate III., Fig. 5). Elytra blueblack and very shiny. The legs and anteunæ are pale reddishbrown. It is found under stones and bark.

\section{Genus Nebria, Latr.}

Labrum truneated at the end. Mandibles with a small double tooth on the inner edge. The third joint of the antennæe is as long as, or longer than the first. These beetles are found in hilly distriets, on the banks of brooks and streains, and on the edges of lakes.

* N. brevicollis, Fabr. (Plate III., Fig. 6). Elytra black, punetate-striate; antennæ, tibix, and tarsi brown. It should be looked for under stones.

* $N$. livida, Linn. This species is distinguished by its larger size and brownish-yellow eolour. It is rather loeal.

Genus Clivina, Latr.

These are snall elongated beetles, with two teeth on the 
front tibie and onc on the middle pair. The first two joints of the antemne are flattened.

* C. fossor, Linn. (Plate III., Fig. 7). Antcnnæ and legs red. Pronotum almost quadrangular. It frequents gardeu refuse, and is also found undcr stones in damp, sandy places.

Genus Brachinus, Weber.

Body elongated, oval, with a long red pronotum. The species of this genus live gregariously undcr stones, and if disturbed eject a fluid from the abdomen which volatilizes, on contact with the air, with a slight report.

* B. crepitans, Linn., the Bombardier Bectlc (Plate III., Fig. 8). The third and fourth joints of the antennee are black, and the elytra bluc-black and finely punctate-striate. It is cornmon on the south coast of England, especially on the chalk, and also near the moutl of the Thamcs.

* B. explodens, Duft. This has also the third and fourth joints of the antenne black, but is smaller and more finely punctured. It is forurd in similar localities to the last species.

\section{Genus Lebia, Latr.}

Elongated oval beetles with a heart-shaped thorax. They are small and generally brightly coloured, and arc to be sought for under stones, on bushes, and in cracks in the ground.

The four following spccies are all found in Britain:

* T. chlorocephala, Hoff. (Plate III., Fig 9). Wing-cases with the interspaces between the striæ distinctly punctured. It is not uncommon in this country, and may be sought for under stones.

* L. cyanocephala, Linn. This is distinguished by the black tips of the fcmora. The habits of this species are similar to those of the last. It is very local. 
- L. crux minor, Linn. Smaller than the last species, with orange-coloured elytra, marked with a black cross. It is scarce and local.

* L. hcemorrhoidalis, Fabr. This is the smallest species. It has black wing-cases with red tips. It lives on bushes, and is extremely rare.

Genus Cxmindis, Latr.

This genus resembles Brachinus, but has a broader thorax, and is flatter. The species are found under stones on the borders of woods.

C. humeralis, Fabr. (Plate III., Fig. 10). Elytra strongly striated with yellow shoulder spots. This beetle hibernates under stones, but is not gregarious. It is common in many parts of Europe.

Genus Loricera, Latr.

These are morc compresscd than the specics of Cymindis. The first joint of the antennæe is long, and has long stiff hairs upon it, as is the case also with the six following joints. These beetles are found under damp leaves and near ponds.

* L. pilicornis, Fabr. (Plate III., Fig. 11). This is the only species found in Britain. It is greenish-bronze, with the elytra punctatc-striate. It frequents damp places.

\section{Genus Panagæus, Latr.}

Pronotum round; elytra broader than in the last genus. They are found in sandy places, under moss, and hibcrnate.

* P. crux major, Linn. (Plate III., Fig. 12). This species varies, and the transverse black band is somctimes found broken up into three round spots (var., trimaculatus, Dej.). It is found under stones and moss, but is local.

* $P$. quadripustulatus, Sturm, resembles the last species, but 
the two posterior reddish spots are bordered with black all round.

\section{Genus Chlakius, Bon.}

Moderate-sized beetles with a more or less broad pronotum and filiform antennæe, the third joint of which is longer than the fourth. They live under moss and stones, near water.

* C. schranki, Duft. (Plate III., Fig. 13). Thorax green, with a golden or coppery lustre; legs rusty-red. It frequents danp places in meadows, and the banks of streams, but is very rare in Britain.

* C. nigricornis, Fabr., is similar, but has the antennæ black, with the exception of the first joint, which is rusty-red.

* C. vestitus, Fabr. (I'late III., Fig. 14), has the edges of the elytra, as well as the antennæe and legs, yellow. It is conmon in damp places in the neighbourhood of London.

\section{Genus I'uecilus, Bon.}

The first joint of the antennæ is laterally compressed so as to form a sharp ridge above. These beetles must be sought for under stones.

* P. cupreus, Linn. (Plate III., Fig. 15). Wing-cases metallicgreen, coppery-red, blue, greenish, or blue-black. The first joint of the antennæe is reddish-brown. It is common and widely distributed.

* P. lepidus, Fabr., is sinilar, but wingless. It has the antennæ completely black. It is very local.

* $P$. dimidiatus, Oliv. Elytra punctate-striate. Base of antennæ reddish-brown. It is rare.

\section{Genus Omaseus, Ziegl.}

Black beetles of moderate size, with the first joint of t'心 antennix rounded at the end. Some of the species are 
apterous. Elytra elongated, and only slightly eonvex. They may be found running on paths, or nnder stones.

" O. vulgaris, Linn. (Plate III., Fig. 16). The thorax is obtuse, narrower behind than in front, with a eorrugated groove and two deep longitudinal depressions. It is a common speeies.

* O. nigrita, Fabr. Much smaller than the last, and with the elytra grooved with three deep punetures.

Genus Sphodrus, Clairv.

Body elongated, oval. Antennæ half the length of the body, finely pubescent from the fourth joint onwards. They frequent damp plaees in woods, under stones, \&c., but are also sometimes met with in eellars and outhouses.

* S. leucophthalmus, Linn. (Plate III., Fig. 17). Elytra finely punctate-striate. It must be looked for in damp places, under stones, and beneath fallen leaves, or in eellars.

\section{Genus Steropus, Ziegl.}

This genus resembles the last, but the pronotum is more rounded behind. It is found on paths and under stones.

* S. madidus, Fabr. (Plate III., Fig. 18). Elytra with three deep punctures. It is fairly eommon beneath stones, \&c.

* $S$. cethiops, Illig., is like the last species, but has a deep eoneavity in the hinder angles of the pronotum. It is found in mountainous distriets.

\section{Genus Pterostichos, Bon.}

Blaek, apterous beetles of moderate size, with the thorax narrower behind than in front. They are also found boneath stones, especially in hilly districts.

* P. niger, Fabr. (Plate III., Fig. 19). Wing-crses withont punetures in the interspaces. Common unler stones. 
* P. parumpunctatus, Germ. Wing-cases with a metallic lustre, oval, and deeply striated, with three punctures in the third interspace. It is found under stones on hill-sides.

P. metallicus, Fabr. (Plate III., Fig. 21). This is distinguished by the coppery lustre of the wing-cases. It is common in mountainous districts on the Continent.

\section{Genus ABAx, Boll.}

Rather large, black beetles, with a very broad thorax, and a compressed form. They are found under stones and moss.

* A. striola, Fabr. (Plate III., Fig. 20). Thorax widest in the middle, with two deep longitudinal depressions. It is common in many parts of Britain.

\section{Genus MoLors, Ziegl.}

This genus resembles the last, but the wing-cases are somewhat convex, and the pronotum is more rounded. Their habits are the same as those of Pterostichus.

M. terricola, Fabr. (Plate III., Fig. 22). Thorax heartshaped; wing-cases smoothly furrowed. It is common on wooded hills.

Genus Zabrus, Clairv.

These are easily distinguished by their stout, almost cyclindrical shape, which separates them from all the allied genera. They live in fields.

* Z. gibbus, Fabr. (Plate III., Fig. 23). These humpbacked black beetles are sometimes found trodden upon on field paths. They are said to live on the grain of wheat, and the larv on the shoots and young corn; but most ground-beetles feed only on insects, and this is the nost notable exception among them. 


\section{Genus Anisodactrudus, Dej.}

Compact, flattened beetles, with four expanded joints to the front tarsi in the males. They are found under stones.

* A. binotatus, Fabr. Shining black, with deeply-furrowed wing-cases, and an almost quadrangular pronotum. The antennæ are rusty-red at the base, and the legs either rustyred or black. It is common under stoncs, and flies about in the fields in early spring. Its length is $10-12 \mathrm{~mm}$.

\section{Genus Amara, Bon.}

This genus is very like the last. The terminal joints of the maxillary palpi are oval. There are a number of species which are very difficult to distinguish. They are found under stones and among fallen leaves.

* A. communis, Illig. (Plate III., Fig. 25). The first three joints of the antennx, and the base of the fourth, as well as the tibix, are red. The wing-cases are simply striped. It is about $8 \mathrm{~mm}$. in length, and is widely distributed.

* A. plcbcia, Gyll. The front of the pronotum is excavated. The antennæ arc brownish, with the first three joints and the tibire orange. It is about $7 \mathrm{~mm}$. in length. It is conmon.

* A. fulva, De Geer. Shining reddish-brown, with two excavations on the sides of the pronotum postcriorly. Elytra punctate-striate. It is about the same size as the preceding, and frequents sandy places.

* A. obsoleta, Dej. Oval, bronzy, with the first three joints of the antenne red. Pronotum with only a shallow impression. Length, about $9 \mathrm{~mm}$. It is widcly distributed.

* A. acuminatce, Payk. 'This is similar to the last, but with the clytra somewhat pointed and fincly striatcd. Lcnoth, 1U min. Widcly distributed, but lucul. 
* A. trivialis, Gyll. The first three joints of the antennie and the femora are orange-coloured. The wing-cases are finely striated. Length, $7 \mathrm{~mm}$. It is common throughout the kingdom.

*A. familiaris, Duft. Long, oval, with the upper surface greenish-bronze. The first three joints of the antennx, and the base of the fourth, as well as the legs, are reddish-brown. Wing-cases faintly punctate-striate. Length, 7-8 mm. Common.

*A. vulgaris, Dej. The strixe on the elytra are deepest beyond the middle. The antennæ are black, with the first joint, and sometimes also the under-surface of the second, red. The legs are entirely black. It has a length of $7-8 \mathrm{~mm}$.

Genus Axchomenus, Erichs. (Platynus, Bon.)

Flattened beetles, of moderate size, many of them richly coloured, with the labrum truncated and the claws simple. They live under stones, in rotten wood, and beneath fallen leaves.

* A. sexpunctatus, Linn. (Plate III., Fig. 26). The reddishgolden wing-cases have a row of five or six deep punctures. It is found in damp places on heaths, but is not common. It is about $6 \mathrm{~mm}$. long.

* A. prasinus, Fabr. Much smaller than the last. Wingcases brown, with a greenish spot behind.

* A. albipes, Fabr. This species is winged and larger than the last, and entirely black except the antenne and legs, which are pale ochre-yellow. It is about $8 \mathrm{~mm}$. long. Abundant in damp places.

* A. angusticollis, Fabr. (junceus, Scop.) Black, with pitchybrown antenne and legs. It is nearly twice as large as the last species. It is common under loose bark, \&c.

* A. marginatus, Linn. Upper surface bright green. Wing- 
cases edged with white. Length, $10 \mathrm{~mm}$. It frequents the banks of streans and ponds.

* A. viduus, Panz. Dark bronzy-green above; legs and feet black. It is rather smaller than the last species.

\section{Genus Harpalus, Latr.}

Usually dark-coloured beetles of moderate size, with the pronotum as large as the abdomen. They are found under stones and on paths.

* H. azureus, Fabr. Blue or green above, and pitchy-brown beneath, with red legs. Local on the chalk.

* H. sabulicola, Panz. This is more than twice as large as the last spccies. The pronotum is thickly punctured, and the legs are reddish-brown. It is found in challiy and sandy places.

* H. obscurus, Fabr. (nec Daws). Is very similar, but rather smaller. This species is very rare.

*H. ruficomis, Fabr. (Plate III., Fig. 28). Pronotum only punctured on the front and hind borders. The antennæ have a thick golden-yellow pubescence. It is common in gardens, where it is often dug up with the mould.

* H. ceneus, Fabr. (Plate III., Fig. 27). Green, blue, copperyred or blackish, with the antennie and legs red. The thorax has the angles obtuse. It is larger than azureus, and is very common throughout the kingdom.

\section{Genus Callistus, Bon.}

Pronotum ncarly heart-shaped, antennæ filiform, not pubescent. The only spccies is richly coloured, and is found under stones.

* C. lunatus, Fabr. (Platc III., Fig. 29). Pronotum red, elytra yellow, with three black spots on cach. It is local, being found chictly in chalky districts. 
Genus Bembidium, Latr.

These are delicate little beetles, for the most part with an elongated pronotum and variously coloured wing-cases. They are found under stones, in meadows, and are common in damp sand, under reeds and fallen leaves.

* B. quadrimaculatum, Panz. Shining black, with the base of the antennæ and legs yellow. Length, $4 \mathrm{~mm}$.

* B. articulatum, Panz. Metallic green, with the base of the antennæe and the legs yellow. Wing-cases yellowish-brown in front and brown behind, with a yellow spot. It is of the same size as the last species, and is most commonly met with on the banks of streans and ponds.

* B. lampros, Herbst. Wing-cases shining bronze colour, striated. The base of the anteunæ and the legs are red. The pronotum is short and heart-shaped. Length, $4 \mathrm{~mm}$.

* B. decorum, Panz. The wing-cases are elongated, greenishblue, with seven strongly-punctured strix. The base of the antennæ, as well as the legs, are orange-colour. Length, $5 \mathrm{~mm}$.

* B. (Tachypus) flavipes, Linn. This species is shining coppery with green spots. The base of the anteunæ, the palpi, and legs are entirely yellowish-brown. Length, $5 \mathrm{mmm}$.

* B. biguttatum, Fabr. (Plate III., Fig. 30). The base of the antennie, the legs, and a round spor on the wing-cases are orange-colour, and the tips of the wing-cases are usually also tipped with this colour. Length, about $4 \mathrm{~mm}$.

* B. quadriguttatum, Fabr. This species is black, with two pale yellow spots on the wing-cases. The base of the antennx and the legs are reddish-ochreous. The length is about $5 \mathrm{~mm}$.

Fanily III. DYTISCID无 (Carnivorous Water Beetles). Antennse with ten or eleven joints, setiform or filiform; 
body oval; pronotum broader than long. The last pair of legs are flattened and paddle-shaped, set with long bristles. The front tarsi have small pulvilli in the males of the larger species, which enable tliem to keep their footing on smooth surfaces. They are more common in standing than in flowing water.

\section{Genus Haliplus, Latr.}

Small, elongated, oval beetles, measuring about $3-4 \mathrm{~mm}$. in length, with the body stout and strongly convex beneath. The pronotum is produced into a spine behind. They live in stagnant watcr.

* H. favicollis, Sturm. Pale yellowish-brown, with the elytra darkly punctate-striate. It is found in ditches, \&c., but is rather local.

* H. ruficollis, De Geer. Shortly oval, Jellowish-brown; pronotum with a deep longitudinal furrow on each side. This species is of common occurrence in stagnant pools, but is also occasionally found in running streams.

Genus Hyphydus, Illig.

Body globose; oval, strongly convex, both above and beneatl. The hind tarsi have two claws of unequal size. These beetles abound in stagnant water.

* H. ovatus, Linn. (Plate IV., Fig. 1). Rusty-red, with the wing-cases darker, often blackish. It is larger than the species of Haliplus, and is common in pools and ditches.

\section{Genus Hydroporus, Clairv.}

Pody elongated, oval; hind legs filiform. The genus includes a large number of small specics, some of which live in Howing, and others ill stagnant, water. 
*H. incqualis, Fabr. Rusty-ycllow, everywhere closely and thickly punctured. The anterior and posterior borders of the pronotum are black. Length, $3 \mathrm{~mm}$. It abounds in ponds and ditches.

* H. picipes, Fabr., is $5 \mathrm{~mm}$. long. The upper surface and legs are dark orange, and the pronotum is black behind, whilst the lateral borders of the wing-cases are dark brown. It is common in ditches and puddles in the London district.

* H. planus, Fabr. Black, somewhat flattened, with the front and back of the head reddish-brown. Each elytron has five rows of coarse punctures. Length, $6 \mathrm{~mm}$. It is common in ponds and ditches.

* H. palustris, Linn. (Plate IV., Fig. 2). Wing-cases dark brown; proutum bordered with reddish-brown on the sides. Prosternum and legs rusty-red. Length, 4-5 $\mathrm{mm}$. It is common everywhere in standing water.

\section{Genus Laccophilus, Leach.}

These are oval, slightly convex beetles. The scutellum is not visible. The antenna are slender and filiform. They are found in clcar standing water, and are very restless, constantly swimming about near the bottom.

* I. minutus, Linn., is $4-5 \mathrm{~mm}$. in length. The wing-cases are dark brown, with four large and two smaller spots. It is common everywherc.

\section{Genus Colymbetes, Clairv.}

Scutellum distinct. The prosternum is prolonged into a point behind. Front legs cxpanded in the malcs. They are found in lakes and ponds.

* C. (Cymatopterus) fuscus, Linn. (Plate IV., Fig. 3), is the 


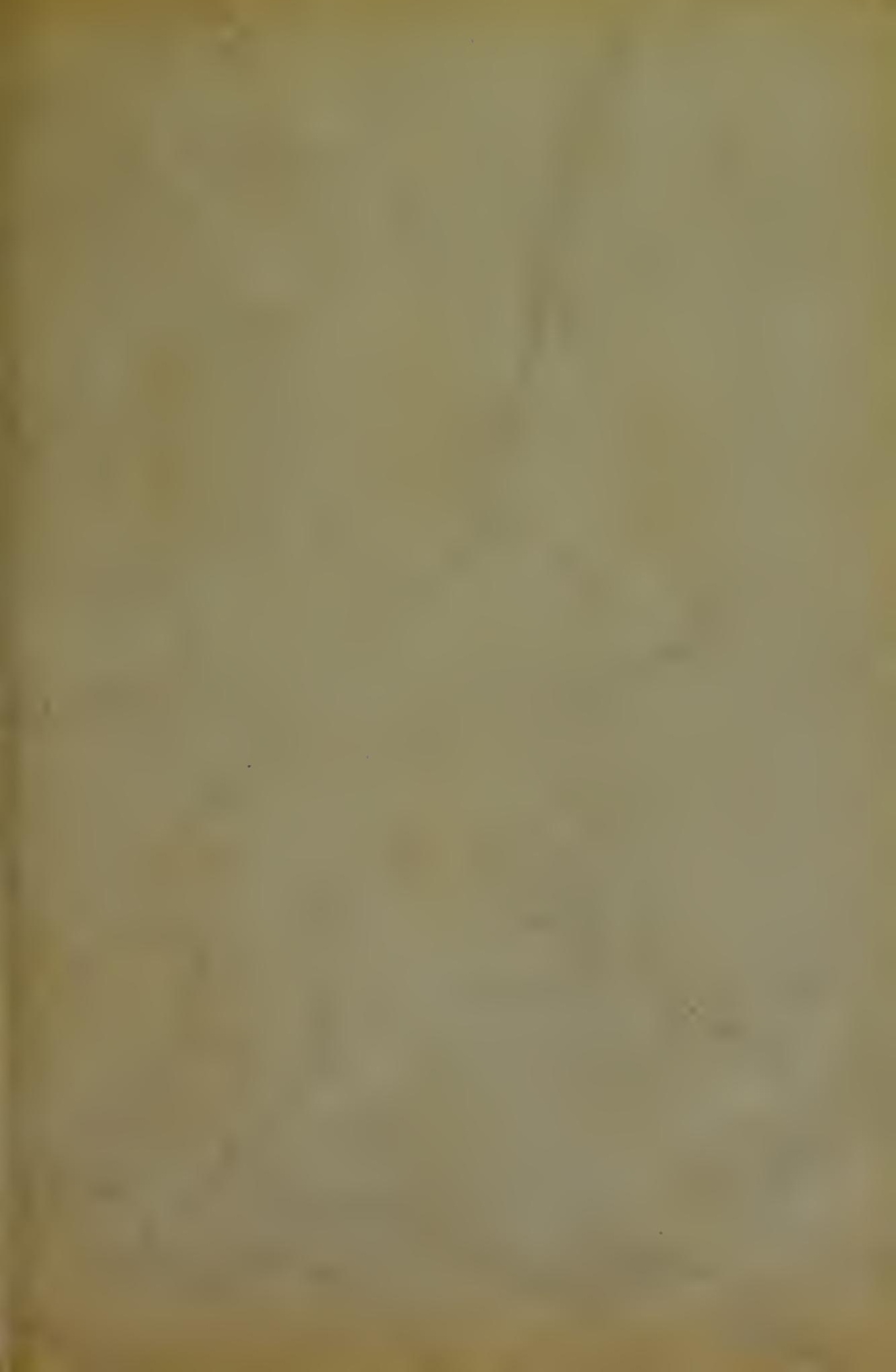




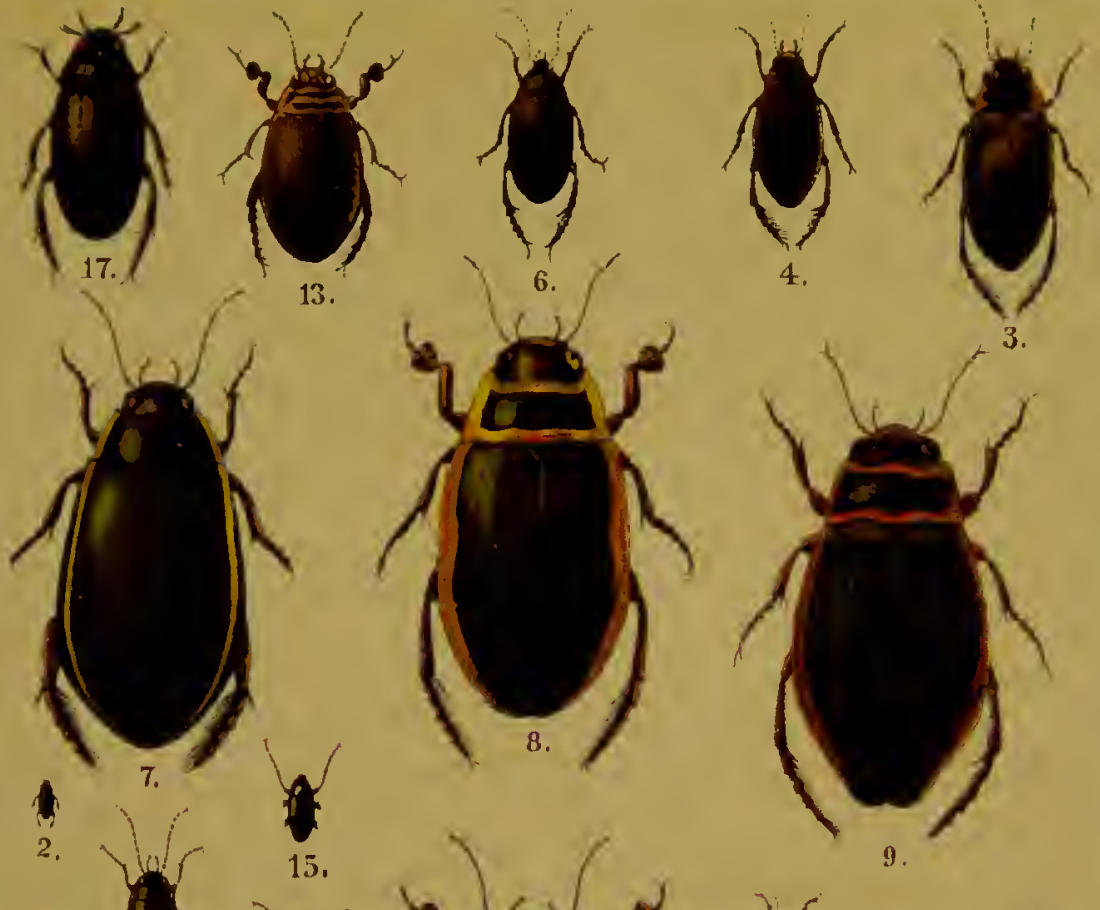

a
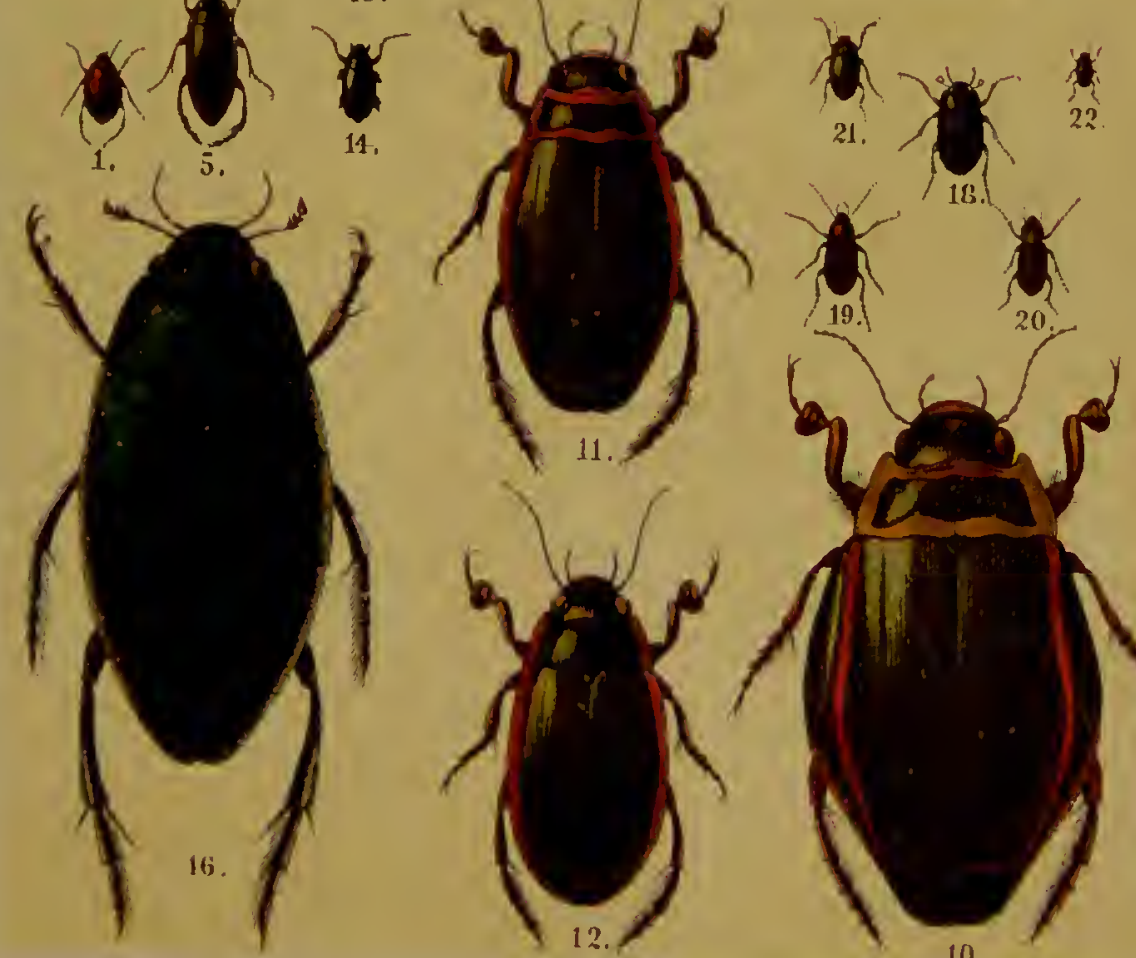

largest of the genus. The under-surface is black, with brown legs. It is common everywhere. Length, $16 \mathrm{~mm}$.

* C. (Rhantus) pulverosus, Stephens, is $12 \mathrm{~mm}$. long, and is flattened; the wing-cases are brownish-yellow sprinkled with black dots. The under-surface is entirely black.

* C. (Rhantus) notatus, Fabr. (Plate IV., Fig. 4), resembles the last species, but has the prosternum yellow. Length, $10 \mathrm{~mm}$. Both are common in the London district, though local elsewhere.

Genus Ilybius, Erichs.

This genus is similar to the last, but the two end joints of the labial palpi are nearly equal in length. They are moderatesized, somewhat convex beetles, and live in wells and in other standing water.

* I. fuliginosus, Fabr. (Plate IV., Fig. 5). The pronotum and elytra are bronzy, with a uniformly broad, yellowish-brown border.

* I. fenestratus, Fabr., is only slightly convex, and has the border narrowed behind. Both these species are about $10 \mathrm{~mm}$. in length, and are common in ditches and ponds.

\section{Genus Agabus, Leach.}

Appendage of the prosternum pointed; scutellum distinct; hind legs with two equal movable claws. They are flattened bcetles, mostly brown, and of medium size. They are generally found in running water, and in the winter reside gregariously uuder inoss or at the roots of trees.

* A. bipustulatus, Linn. (Plate IV., Fig. 6). This species is oval, and has two dots on the front of the head. It is common everywhere. Length, 10 mun.

*A. chulconotus, Panz., is sinaller than the last species, and 
of a blackish-brown colour. The raised borders of the wingcases and the legs are reddish-brown. It also is common.

* A. maculatus, Linn., is $8 \mathrm{~mm}$. in length. It is oval, with the elytra yellow, spotted with brown, and rusty-red legs. It is common everywhere in rumning streams.

\section{Genus Cybister, Curtis (Trogus, Leach).}

Body broad, irregularly oval. The appendage of the prosternum is pointed behind. The front legs of the males are expanded and flattened. They live in stagnant water.

C. Roeselii, Bergst. (Plate IV., Fig. 7). Pronotum and wingcases smooth in the male, finely ribbed in the female. It is common in large fish-ponds on the Continent, but does not appear to be indigenous to Britain.

Genus Dytiscus, Linn. (True Water Beetles).

Elongated oval, slightly convex. The front tarsi are expanded in the males into a rounded plate. The elytra are generally ridged in the females. They frequent standing water.

* D. marginalis, Linn. (Plate IV., Fig. 8, male; Fig. 9, female). The appendage of the prosternum is bluntly pointed. It is common in ponds and stagnant water.

D. latissimus, Linn. (Plate IV., Fig. 10). Elytra with very broad lateral borders. This large beetle, which attains a length of nearly $4 \mathrm{~cm}$., is found only in lakes on the Continent; it is not British.

* D. circumcinctus, Ahrens (Plate IV., Fig. 11). This is similar to the last species, but smaller. The process of the metasternum is narrow and pointed. It lives in fish-ponds.

* D. circumflexus, Fabr., is similar, but the female las 
smooth wing-eases. The seutellum is rusty-red, and the appendage of the metasternum is narrow and pointed. It is found in ponds and ditches, but is not common.

* D. punctulatus, Fabr. (Plate IV., Fig. 12). Metasternum produced behind into two blunt and rounded processes. It is ehiefly found in running water, and is common and widely distributed.

Genus AcILIUS, Leach.

Body oval, slightly convex. The appendage of the prosternum is rounded at the end. The front tibix of the niales are expanded and flattened. They are found in any kind of standing water.

* A. sulcatus, Linn. (Plate IV., Fig. 13). Shortly oval. Wing-eases with four broad, hairy furrows in the female. It is common in lakes and ponds.

Genus Hydaticus, Leach.

Slightly convex species, elongated ovate. The projection on the prosternum is rounded at the end. The males have pulvilli of nearly equal size on the under-surface of the tarsi. The wing-cases are not furrowed in the females. They are of nıderate size, and may be found in ditches, swamps, and stagnant water generally.

* H. transversalis, Fabr. Has a length of about $13 \mathrm{~mm}$. It is black, with the anterior and lateral borders of the pronotum ferruginous. The wing-cases are broadly bordered with yellow, and there is a narrow trausverse band of the same colour at the base. The middle tarsi of the males lave three expanded joints, and are provided with pulvilli beneath. 


\section{FAMILY IV. GYRINID死 (Whirligig Beetles).}

These are smaller speeies than those of the last family. They are shiny beetles, and are remarkable for having the eyes completely divided in the middle, as if they had four eyes. The antennæ have a large basal joint, and the remaining joints have the form of a small fusiform elub. It is a small family, and only six speeies (whieh are not easy to identify) are found in Britain.

\section{Genus Gyrixus, Linn.}

Wing-eases punetate-striate. They are found gregariously in standing or slowly flowing water, where they describe eircles on the surfaee. They have an air-bladder at the end of the abdomen, and are good divers.

* G. natator, Fabr. (Plate IV., Fig. 14). This is bronze colour beneath. The legs are reddish-brown. It is a eommon species.

\section{Genus Orectochilus, Laeord.}

Wing-eases not punetate-striate. They live only in running water, partly under stones and water-weeds, and partly on the surfaee.

* O. villosus, Fabr. (Ilate IV., Fig. 15). The only British speeies. It is elongated, convex, with a green shine on the upper surfaee. It is rusty-red beneath. It hides in the daytime, and swims about at night.

\section{FAMIILY V. HYDROPHILIDE.}

Body oval, or nearly round. Antennæ very short, not longer than the head, and terminating in a elub. The hind legs are broadly flattened, and eiliated. They live in standing water, and swin by moving the legs alternately. and not like oars, 
and rise to the surface from time to time to take in air. They may be brought to the top of the water by stirring up the mud at the bottom, and can then be caught with a net.

\section{Genus Hydrophilus, Fabr.}

Antennæe with nine joints, the sccond being conical. The point of the metasternum projects far beyond the hind coxæ. They are large smooth beetles, and are common in standing water almost all the ycar through.

* H. piceus, Linn. (Plate IV., Fig. 16). Wing-cases with a small pointed tooth. The ridge beneatlı the thorax is deeply grooved in front. The larvæ feeds on water-plants, but the perfect insect preys upon aquatic insects and fish-spawn. The eggs are laid in a shining silvery sac, which floats on the surface of the water. It is very local.

\section{Genus Hydrobius, Leach.}

Body oval, or elongated; hind tarsi only slightly compressed. The last segment of the maxillary palpi is longer than the one prcceding. They abound in standing water, at the roots of aquatic plants.

* H. (Hydrous) caraboides, Fabr. (Plate IV., Fig. 17). This species is black and convex. The hind tarsi are strongly compressed and ciliated. It is common in stagnant water.

* H. fuscipes, Linn. (Plate IV., Fig. 18), is moderatcly convex, black, or pitchy-brown. The elytra are punctate-striate, with a row of larger punctures. Length, $8 \mathrm{~mm}$. Common.

H. globulus, I'ayk. This little species is only $3-4 \mathrm{~mm}$. in lcugth. It is brown, with the clytra more distinctly punctute than the head and thorax. It is widely distributed. 


\section{Genus Philhiydrus, Sol.}

Body elongated, oval. Antennæ with nine joints, with the second conical. Only the mesostcrnum is liceled. The hind legs are only slightly compressed. These bectles are found in standing water.

* P. lividus, Forst. (Plate IV., Fig. 19). This is a moderatcly convex, brownish-yellow bcetle. The wing-cases are without an impressed sutural line. It is a common species.

Genus Laccobius, Erichs.

Body small, almost hemispherical. Antennæ with eight joints, with a long three-jointed club. The lind legs have a row of swimming hairs on the upper surface. They live in standing water, at the roots of aquatic plants.

* L. minutus, Linn. Only $3-4 \mathrm{~mm}$. in length. Elytra greyish-yellow, spangled with black, closcly punctate-striate. It is not common.

\section{Genus Berosus, Leach.}

Body elongated, oval. The wing-cases arc deeply punctatestriate. The hind tibix and tarsi are ciliated. Thcy live at the roots of plants growing in standing water:

* B. luridus, Linu. This is a very convex, dirty brownishycllow inscct. The wing-cases arc generally spotted with darker, and terminate in a point. Length, 4-5 $\mathrm{mm}$. It is found in pools, but is local.

\section{Genus HeLophorus, Fabr.}

These arc for the most part longish, oval little beetles, with nine joints to the antennæ, the last three of which arc enlarged. The thorax has five longitudinal furrows. They live: on the margin of standing water. 
* H. aquaticus, Linn. (Plate IV., Fig. 20). Wing-cases deeply punctate-striate, dark brownish-yellow, with a metallic shine. It varies considerably in size. It is widely distributed.

* H. granularis, Linn., is only $2 \mathrm{~mm}$. in length, brownishyellow, with indistinct black spots, and a small distinct dark spot beyond the middle of the suture. It is rare.

\section{Ochthebius, Lerch.}

Thorax narrowed bchind. Antennæ with a club composcd of five joints. The first joint of the labial palpi is very short, and the two next are of equal length. They live on the margins of standing water and brooks, under stones and macerated twigs.

* O. pygmcens, Fabr. Only $1 \frac{1}{2} \mathrm{~mm}$. long, oval, slightly convex, pale pitch-brown. The whole of the thorax and abdomen is uniformly punctate-striate. It is a common species.

\section{Genus Hydrana, Kugel.}

Quite small species of an elongated form, with an octagonal thorax, having a curved excavation on each side. The wingcases are longer than broad. They are found under watcrplants and under stones.

* H. gracilis, Germ. Black and somewhat convex, with the antennæ, legs and palpi light red. The wing-cases are dark reddish-brown, scarcely broader than the thorax, each with six rows of decp punctures, not closely placed. Length, 1-2 mm.

\section{Genus Cxclonotom, Erichs.}

Body hemisphcrical. Wing-cases separately rounded behind. The inctasternum is kceled and projects betweel the iniddle coxic. They arc found in stagnant water.

* C. orbiculare, Fabr. Shining black, denscly punctate. 
Wing-cases with a longitudinal line next to the suture, which disippears in front. Length, $3-4 \mathrm{~mm}$. It is not uncommon.

\section{Genus Spharidium, Fabr.}

Slightly oval beetles, having both of the ely tra rounded behind. The inetasternum does not in these extend between the iniddle "nxie. They do not live in the water, but in fresh dung.

* S. scarabocoides, Fabr. Wing-cases with a large and often indistinct blood-red spot at the base, and a large yellow one at the extrcmity. It is a common species.

* S. bipustulatum, Fabr. (Plate IV., Fig. 21). Smaller than the last species. The pronotum has narrow yellow lateral horders, and so have the elytra, which also have a large yellow spot at the tip. It is rather common.

\section{Genus Cerrcyon, Leach.}

Small, smooth, rounded bcetles. The prothorax has a small point near the middle, but the metasternum does not extend between the middle coxre. Somc live in damp places, under stones, and others in dung.

* C. flavipes, Fabr. (Plate IV., Fig. 22). Moderately convex, black and shining. The wing-cases are reddish-ochreous on the lateral borders, and at the tip often reddisli-brown. It is very common.

\section{Family VI. STAPBYLINID瓜 (Rove Beetles).}

Wing-cases much reduced in length, generally covering only the wings and the base of the abdomen. The abdomen is composed of seven or eight freely movable segments. This is a very large family, comprising, for the most part, little elongated, black species, which live beneath moss, bark and stones, in decomposing substances and animal rcfuse, in the 
ground, in fungi, in ant-hills, on damp sandy shores, and on flowers. The larvæ, which resemble then closely, generally prey upon other insects. Many of the beetles have a peculiar odour, and when approached raise their tails. Many species fly in the sunshine, and occasionally get in to the human eye. These numerous little insects are vcry hard to identify, and we shall therefore only mention a few of the mors important gencra.

\section{Genus Myrmedonia, Erichs.}

Body elongated; head separated from the thorax by a short neck. The antennæ are longer than the head, the second joint being much shorter than the third. The maxillie are bilobate, with fine pubescence. They are common under stones, especially where there are ants.

* Mr. canaliculata, Fabr. Brick-red, closely punctured, with a black transversc band across the middle of the abdomen. The pronotum is rather longer than broad, with rounded angles. It is common in the vicinity of ant-nests, under stones, \&c.

\section{Genus Homalota, Mannerh.}

Maxillæ with small spines on the inncr margin. There are no ocelli. This is a large genus of several hundred sniall species, mostly only $3-4 \mathrm{~mm}$. in length, which abound beneath stones, and in damp places.

*H. fungi, Grav. Black and rather shining. The legs and antenne are reddish-brown, the first joint of the latter being somewhat swollen. The pronotum is sliglitly longer than the wing-cases. It abounds in fungi and in damp localitics.

* H.graminicola, Grav. Shining black, with silky down. The pronotum is somcwhat quadrate, with two decp depressions. the legrs are pitchy, with red tursi. It is very common in fundi. 


\section{Genus Aleocilara, Grav}

Labial palpi four-jointed; all the tarsi five-jointed. The pronotum has the edges not raised. They vary from $2-5 \mathrm{~mm}$. in length, and live in dung.

A. fuscipes, Fabr. Antennæ half as long again as the body, thickened in the middle and red at the base. The legs and wing-cases are red, the latter black towards the scutellum and at the sides. Length, 5-6 mm. A very common species.

\section{Genus Lomecirusa, Grav.}

Labial palpi three-jointed. Pronotum with raised lateral borders. The front tarsi with four, the hind tarsi with five, joints. They live in the company of ants.

* L. paradloxa, Grav. The last joint of the antennæ is thicker than it is long, and is compressed. The thorax is smooth, slightly narrowed, and rounded at the sides. Length, $5 \mathrm{~mm}$. It is found in the nests of the red ant.

\section{Genus TaChyponus, Grav.}

Wing-cases longer than the pronotum; antennæ filiform. Maxillary palpi, with the terminal joint pyramidal. The abdomen is bordered. They are found under decomposing regetable matter.

* T. obtusus, Linn. Body smooth, orange-coloured; thorax, and the front half of the wing-cases and the tip of the abdomen, blue-black. Length, 4-5 mm. Fairly common.

* T. brunneus, Fabr. Rather smaller than the last species. The wing-cases and abdomen are distinctly punctured, the latter being entirely orange-coloured. It is a common species.

Genus Tachinus, Grav.

Elytra as in the last genus; the maxillary palpi are, however, 
filiform, with the last joint neither thicker nor longer than the last but one. They are found in dung, on the exuded sap of trees, and in damp places.

T. mufipes, De Gcer. Dark brown, convex, finely and closely punctured. The base of the antennæe and the legs are orange-coloured. Length, $7 \mathrm{~mm}$. It is a common species.

* T. flavipes, Fabr. Of the same size as the preceding, but less convex; dark brown, with light reddish-brown legs and wing-eases. It is not so eommon.

\section{Genus Bolitobius, Stephens.}

Elytra as long as the thorax. Antennæ and maxillary palpi filiform. These beetles are found in fungi and under decomposing vegetable débris.

* B. atricapillus, Fabr. This species is bright red, with the head, sternum, elytra and tip of the abdomen black. On the elytra there is a pale yellow transverse mark near the base, and the posterior border is of the same colour. Length, $6-7 \mathrm{~mm}$. It is common in Boleti.

\section{Genus Quedius, Stephens.}

Antennæ filiform; body elongated, slightly tapering at both extremities; head rounded, with a slight constriction between it and the thorax. They are found in damp and dark places.

* Q. fulgidus, Fabr. Wing-cases black or brick-red, finely punctured and pubescent. The pronotum is expanded at the sides. Length, 6-11 mm. It is common under moss and in cellars from March to November. The larva feeds on maggots.

Genus Creophilus, Stcphens.

Antennæ somewhat clubbed, gradually thickened from the seventh to the tenth joint. I'alpi filiform, the fourth joint 
of the maxillary palpi shorter than the third. Hind tibice with spines. Front tarsi expanded. The only British species is :

* C. maxillosus, Linn. (Plate V., Fig. 1). Head and thorax with hair only on the sides. It is found generally on carrion.

\section{Genus Eyrs, Leach.}

Antennæ slightly thickened only at the end, the sixth to the tenth joint being broad.

* S. hirtus, Linn. (Plate V., Fig. 2). The pubescence on the head, thorax, and the three last abdominal segments is goldenyellow. The wing-cases have a broad, grey, felt-like band upon them. It frequents horse and cow droppings, but is not common.

\section{Genus Leistotrophos, Perty.}

Only the end of the antennx is tapering. The last joint of the maxillary palpi is smaller than the last but one. They live in dung during the summer, and in moss in winter.

* L. nebulosus, Fabr. (Plate V., Fig. 3). Black, with a thick grey pubescence. The base of the antennæ and the legs are orange-coloured, the litter black at the base.

* L. murinus, Linn., is smaller than the last, and has black legrs and palpi. Both species have a predilection for human fieces.

\section{Genus Staphylinus, Linn.}

Antennæ filiform, the terminal joint emarginate at the tip. Palpi filiform, the last joint being as long as that preceding. They live under decomposing vegetable refuse, in dung and carrion, and if disturbed raise the abdomen aud emit a penetruting odour. 

5.

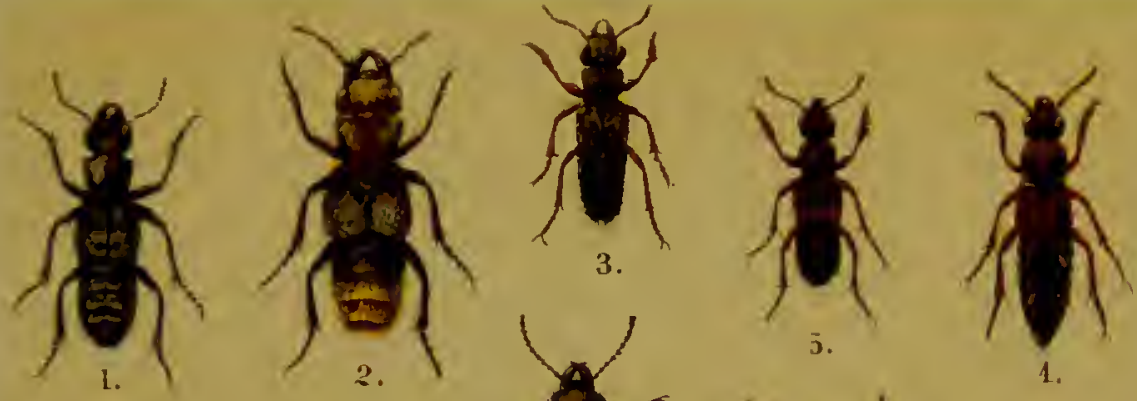

H

9.

8.

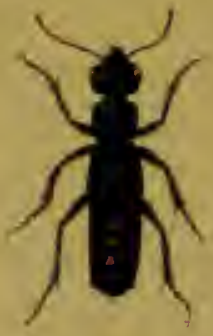

12

fin

7.
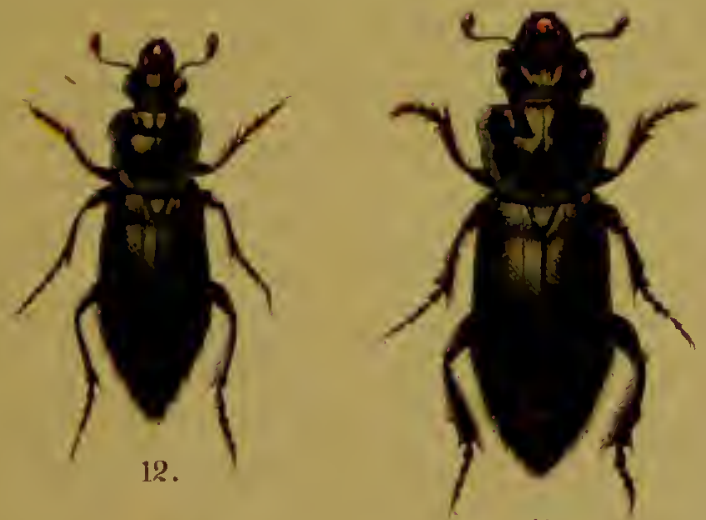

11.

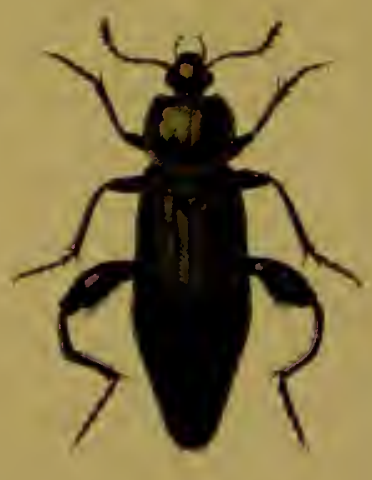

17.

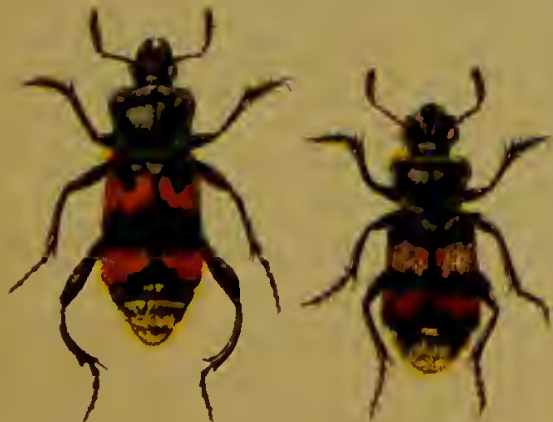

13.
16.

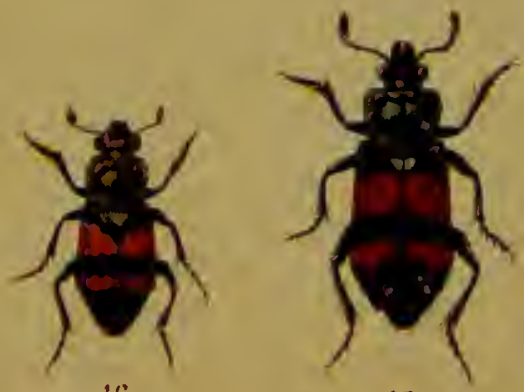

15.

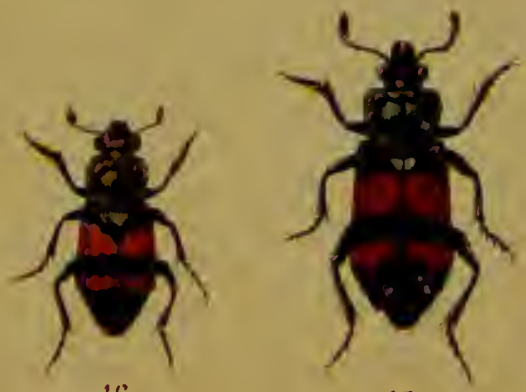



* S. casareus, Cederh. (Plate V., Fig. 4). Black, with a dull gloss; wing-cases and legs red; abdominal segments with golden-yellow lateral spots. It is common on paths and roads.

S. fossor, Scop. (Plate V., Fig. 5). Black, with a dark reddish-brown head and thorax. The elytra, tibiæ, and tarsi are orange-coloured and hairy. The abdominal segments with small, shining, golden spots. Length, $13-15 \mathrm{~mm}$. It is met with in damp moss in woods, and is common on the Continent, though absent from our fauna.

* S. pubescens, De Geer. Rather smaller than the last species; black, spotted with dense brownish-grey pubescence, varied with golden-yellow hair on the head and on the middle of the abdomen. The legs are black. It is not common.

* S. erythropterus, Iinn. Black, with a dull shine, with the base and the end of the antenur, the elytra and legs, red. Scutellum yellow. The last three abdominal segments are spotted with yellow. Length, $13-15 \mathrm{~mm}$. It is found in woods in the north of England.

* S. stercorarizu, Oliv. Black, with the base of the antennæ, the elytra and legs, reddish-brown. The scutellum is velvetyblack. There is a triangular spot on the second and third segments of the abdomen, and a broad silvery-white band on the sixth. Length, 14-15 mm. This species is rare.

\section{Genus Ocypus, Stephens.}

Antennæ more slender than in Staphylinus; abdomen slender and of uniform thickness. The middle coxæ are in contact. These beetles also live in carrion, dung, and decomposing vegretable matter.

* O. olens, Miull. The Devil's Coach-horse (Plate V., Fig. 6). This species is dull black, and is provided with wings. It is 
common throughout the British Isles. The larva makes a pit in which it lies in wait for other insects.

* O. similis, Fabr., is $17-19 \mathrm{~mm}$. in length, dnll black, fincly pubescent, and wingless. The elytra arc only slightly shorter than the pronotum, and are closely punctured, as is also the abdomen. It is found under stones, in moss, \&c., but is local.

* O. cupreus, Ross. Black, and provided with wings. The head and pronotum are bronzy, and the antennæ and palpi red, whilst the elytra are brown, with grey down. The legs are black. It is common under stoncs.

* O. cyancus, Payk. (Plate V., Fig. 7). This species is black, with a dull gloss, finely puncturcd, and is provided with wings. The head, thorax, and wing-cases are dark blue. The antennæ arc tipped witl rusty-brown. Length, $15-22 \mathrm{~mm}$. It is a scarce spccies, which is sometimes met with running over woodland paths.

\section{Genus Philontruus, Leach.}

Antennæ not elbowcd. Hend rounded, square, or oval, with a ncck-like constriction between it and the pronotum, which is as long as it is broad. Wing-cases truncated, middle coxæ in contact or only slightly separated. They are black spccies of moderatc size, and live in putrefying animal and vegetablc matters, under moss and stones, or on the exuded sap of trees.

* P. splendens, Fabr. Shining black, with metallic-grcen elytra. The pronotum is not punctured. The clytra arc rather closely punctured and covered with black hair. Length, 10-13 $\mathrm{mm}$.

* P. coneus, Rossi. This species is black, with the head and thorax bronzy-black, and the wing-cases metallic-green. The hcad is almost quadrilateral, with five punctures between the eyes. The pronotum with two to four punctures on the surface, 
and a row of punctures along the margins. The wing-cases are also finely punctured. Length, $9-15 \mathrm{~mm}$. It is 'common on dung, carrion, and fungi, in which the beetles and larvæ hunt for the grubs of gnats.

*P. nigritulus, Grav. Black and elongated, with the first joints of the antennæ dark pitchy-brown. The legs are generally brownish-yellow. Each row of punctures on the pronotum consists of three. The wing-cases are punctured, with a fine grey pubescence. Length, $4 \mathrm{~mm}$.

P. cyanipennis, Fabr. (Plate V., Fig. 8). Black, with bright blue wing-cases. The head is rounded, with several punctures behind the eyes. Pronotum rather broader than long. It lives in fungi, and, though found in various places on the Continent, is not British.

\section{Genus Xantholinus, Serv.}

Antenne slightly elbowed, with no greater distance between the two than between them and the eyes. Palpi filiform. Wing-cases with the sutural borders ovcrlapping. Coxæ of the middle legs not in contact. They live in decomposing vegetable mattcr and in dung.

* X. fulgidus, Fabr. Shining black, with red elytra and legs. The pronotum is smooth, with a deep groove on each side. The elytra arc irregularly punctured. Length, $9 \mathrm{~mm}$. It is found in vegetable débris, dead wood, \&c.

* X. punctulatus, Payk. Black, with the antennæ, elytra, and legs either dark grecn or rusty-brown. The pronotum is longcr than broad, with very various punctuations. It is a common specics in moss, cut grass, \&c.

\section{Genus Lathrobium, Grav.}

The front of the head projects over the basc of the antennie 
in this genus, and the last joint of the maxillary palpi is tapering. The body is very slender. The species are numerous, and have an elongated form. They live in damp woods under moss, leaves, and stones.

* L. elongatum, Linn. Shining black; antennæ, legs, and wing-cases orange, the last with the base black. The wingcases are longer than the pronotum. The head is nearly round. Length, $8 \mathrm{~mm}$. It is found in woods among moss.

* L. fulvipenne, Grav. Of the same size as the last species. The pronotum is as long as the elytra, which are reddish-brown, closely punctured. It is common in moss, flood-refuse, \&c.

\section{Genus Paderus, Grav.}

Pronotum rounded, nearly oval; wing-cases truncated behind; body slender, with long slender legs; antennæ straight and filiform. They live near brooks and streams, generally gregariously under leaves and stones, but may also be seen running about on the ground.

* P. riparius, Linn. Wing-cases blue; antennæ black, with the base orange. The pronotum, the first four segments of the abdomen, the mesosternum, and legs are orange-coloured. Length, 6-7 mu. A local insect, which likes to hiberuate in rotten willows.

P. ruficollis, Fabr. Blue-black, with a red pronotum, and black antennæ, palpi, and legs. Length, $8-9 \mathrm{~mm}$.

Genus Stenus, Latr.

Abdomen either completely round, or with the upper and nether surfaces separated by a lateral border. The antenne are situated between the eyes. The pronotum is narrower than the head. These beetles live in damp places, such as the banks of brooks, and in swamps, as well as under fullen leaves in woods. There are a great many species. 
* S. binotatus, Ljungh. Black, closely punctured, and pubescent. The antenne and palpi are pitchy-brown, and the front of the head is flat and very slightly furrowed. The tarsi are blackish-brown, the third joint being expanded, and the fourth bilobate. Length, $6 \mathrm{~mm}$. Found in reeds and in damp grass, but local.

* S. biguttatus, Linn. This species is of the same size as the preceding. It is black, with the wing-cases coarsely punctured, each with a small, round, orange spot behind the middle. The abdomen has a border. It is common on sandy shores.

* S. bipunctatus, Erichs., is very similar, but the yellow spots on the wing-cases are everywhere equidistant, and the front of the head is more slightly furrowed. Local.

\section{Genus Oxypords, Fabr.}

Antennæe slightly elbowed, scarcely as long as the head, which is larger and broader than the thorax. The elytra are narrower than the thorax, which is half again as broad as it is long, and is much narrowed bchind. In the males the head is larger, and the end of the sixth abdominal segment is slightly emarginate. They live in fungi.

* O. rufus, Linn. (Plate V., Fig. 9). Shining black, with the pronotum, the first four abdominal segments, and the legs, red. The wing-cases have a large orange-coloured shoulder-spot. They are found in the larger Boleti.

O. maxillosus, Fabr. (Plate V., Fig. 10). Reddish-ochreous, with the head and pronotum pitchy-black. The elytra are pale yellowish-brown, with the extreme tips black. It is found in Agarici.

Genus Bledius, Leach.

Body of nearly uniform breadth throughout. These species are provided with wings. The head is rather narrower than 
the pronotum, which is generally much broader than long. The abdomen has raised laternl borders. The antennæe are elbowed, the first joint being long. The males often have horns on the head or pronotum. They reside in the sand on the banks of streams and lakes, in holes whieh they have made for themselves.

* E. tricornis, Herbst. Black, with reddish-brown antennæ and legs. The elytra are red, and there is a triangular blaek mark on the pronotum. On eaeh side of the front of the head there is a rather long, broadly-eompressed horn. The thorax and elytra are elosely punctured. The end of the abdomen is recl. Length, $5-7 \mathrm{~mm}$. It is only found in salt marshes, \&e.

* B. fracticornis, Payk. Black, with the legs and base of the antennæ red. The elytra are blaek or red, closely and deeply punctured. The pronotum has a longitudinal furrow. Length, $2 \mathrm{~mm}$. It is local.

\section{Genus OxyTelus, Grav.}

Body of uniform breadth, flattened. Wings are present. The head is prominent, and is attaehed to the pronotum by a very short neek. The elytra are short, scareely as long as they are broad, and usually a little broader than the pronotum. They live in dung, under damp moss and dead leaves, and a few in sandy shores. The two following are very eommon species.

* O. rugosus, Fabr. Blaek, and somewhat shining, with reddish pitchy-brown legs. The front of the head, the pronotum, and wing-eases are all deeply and elosely punctured, the pronotum with three longitudinal grooves. Length, $4 \frac{1}{2} \mathrm{~mm}$.

* 0. depressus, Grav. The head, pronotum, and elytra are very finely and closely shagreened, and the front of the head 
is slightly depressed on both sides. On the pronotum there are three longitudinal furrows. Length, $1 \frac{1}{2}-2 \mathrm{~mm}$.

\section{Genus Axthophagus, Grav.}

Body elongated, slightly convex. Wings are present. Thewing-eases are broader than the pronotum. There are no. spines on the tibix. The antennæ are fine and filiform. They live on plants and flowers, espeeially in hilly distriets, and prey. upon other inseets.

A. caraboides, Linn. Reddish-ochreous, with the head and end of the abdomen pitchy-brown. The pronotum is finely punctured, and the wing-cases are elosely and more stronglypunctured. Length, $4 \mathrm{~mm}$.

\section{Genus Omalium, Grav.}

Body generally elongated, often flat. Wings are present. The head (together with the eyes) is almost triangular. The pronotum is short, obeordate, or transverse, narrowed behind. The antennæ are slightly thiekened towards the tips. They are. found on flowering plants and bushes, in grass, and some under the bark of trees in the galleries of wood-boring beetles, thelarvæ of which they feed upon.

* O. rivulare, Payk. Shining black, with the legs and base. of the antennæ yellowish-brown. The wing-cases are darker. The head and pronotum are closely punetured, with two. elongated deep grooves. Length, $3-3 \frac{1}{2} \mathrm{~mm}$. Common in dung, fungi, on flowers, and in the nests of ants.

* O. planum, Payk. Shining black, finely punetured. The. pronotum has a slight furrow and an oblong depression on each. side at the base. The elytra are testaceous, brown, and punctured, and the legrs are of the same eolour. The antenne are testaecous, timed with black. Length, 2-21 mm. Local, but not uneonmmon.", 
Genus Anthoвium, Leach.

Body short and broad, somewhat flattened. Wings are present. The head is nearly triangular, with a smooth front, and rather large, prominent eyes. The pronotum is slightly narrower than the elytra, which almost cover the abdomen. The antennæ are usually thickened towards the extremity. They are found in flowers, and particularly in hilly districts.

* A. ophthalmicum, Payk. Testaceous, finely punctured, with a black head and prominent cyes. The elytra are glossy yellow, and twice as long as the thorax. The abdomen is black, and so are the tips of the antennæ. Length, about $1 \frac{1}{2}-2 \mathrm{~mm}$. It is common in flowers.

* A. minutum, Fabr., is about the same size as the last species. It is black, somewhat shining, with the head slightly punctured. The pronotum has the sides expanded and flat, finely punctured. The wing-cases are pitchy-brown and punctured, truncated at the end in the male, spined in the female. The base of the antennx is testaceous, and so are the legs. It is local, but common where it occurs.

\section{FAMILY VII. SILPHID曆.}

Body flat, sharply margined. Antennæ with eleven joints, rarely with only ten, gradually thickened, or with several of the joints at the end expanded. The front coxæ are conical, and project from their articular pits. The abdomen is composed of six movable segments. They generally live in carrion or in the bark of trees, and thus act as scavengers in nature.

Genus Catops, Fabr.

Body clongated, oval, brown or blackish-brown. The antennx have five cxpanded joints at the end, the second 
of which is the smallest. The last joint of the maxillary palpi is conically tapcring. They are agile insects, which are found under moss, dead leaves and stones, as well as in decomposing animal and vegetable substances.

${ }^{*}$ C. tristis, Panz. Pitchy-black, with the antennæ much thickened, the first six joints bcing reddish-brown, and the remainder (which are broader than they are long) brown. The pronotum is short with rounded sides, and the wingcases are brown and indistinctly striated. The legs are brown, and the taisi rusty-yellow. Length, $4-5 \mathrm{~mm}$. It is common in carrion.

Genus Necrophilus, Illig.

Oval, convex beetles, with the five last joints of the antenure enlarged. The last joint of the maxillary palpi is cylindrical. The wing-cases have a broad, raised border and truncated tips, and are dentated at the sutural angle.

N. subterraneus, Illig. This is the only European species. It is pitchy-black, with the wing-cases punctate-striate. It is found in damp, dark places and under stones, and often in snail-shells. It is common in some mountainous districts in Central Europe, but is not a British species. Length, $5-8 \mathrm{~mm}$.

Genus Necropironus, Fabr. (Burying Beetles).

Elytra truncated. Antennæe with ten joints, with a very large foliated club at the end, formed of four joints. They are common in carrion in the summer, to which they often fly from a considerable distance. They bury it, and lay their eggs in it.

* N. germanicus, Iinn. (Plate V., Fig. 11). This ' large species has reddish-brown clytra, and a rusty-yellow spot on the front of the head. It lives less on carrion than on other 
insects, espeeially dung-beetles, which it attaeks and carries off, and for this purpose it frequents dung-heaps. Very rare in Britain.

*N. humator, Fabr. (Plate V., Fig. 12). Smaller than the last, with the elub of the antennæ orange. It is a eommon speeies.

* N. vespillo, Linn. (Plate V., Fig. 13). Base of the antennæ orange. The front border of the pronotum lias a thiek yellow pubeseenee. The hind tibir are curved. It buries the dead bodies of birds, moles, miee, \&c., and lays its eggs in the earense; it is also frequently met with on flowers. It smells strongly of musk.

* N. vestigator, Herscli. (Plate V., Fig. 14). The thorax is surrounded wilh a yellow, woolly pubescenee. The elub of the antennæ is orange, and the hind tibiæ are straight.

* N. ruspator, Erichs. (Plate V., Fig. 15). Blaek, with only the extreme tip of the abdomen eiliated with yellowish-grey. The bands on the wing-cases are red.

* N. mortuorum, Fabr. (Plate V., Fig. 16). Antennx perfeetly black. The first orange band on the elytra is uninterrupted, but the second is broken at the apex into two large spots. It is found in earrion and in fungi.

\section{Genus Silpira, Linn.}

Body oval or elongated; antennie gradually expanded, or with three or four larger joints at the end. The maxillary palpi are oval or eylindric il above. The pronotum is wedgeshaped or semicireular. They mostly live on carrion, but also prey on living insects. They are to be sought for in dead careases and under stones, and when touehed throw out an evil-smelling liquid both from the mouth and abdomen. 
They also destroy caterpillars, and the only species which is to be regarded as an injurious insect is $S$. atrata, the larvæ of which feed on young bcetroot-plants.

* S. (Necrodes) littoralis, Linn. (Plate V., Fig. 17). Antennæ gradually thickened. 'Pronotum wedge-shaped; elytra truncated, black, with three raised longitudinal lines. They are found in fresh or dried meat, in carrion, under stones, and in damp moss on the banks of streams.

* S. thoracica, Linn. (Plate VI., Fig. 1). Pronotum red, with golden-yellow pubescence; wing-cases with three raised longitudinal lines, and an elcvation in the centre. It may be found on dead slugs and Amphibia, in woods, \&c.

* S. rugosa, Linn. (Plate VI., Fig. 2). Antennæ with three distinct terminal joints. Head and pronotum black, with thick grey pubescence. The elytra are transversely rugose and free from hair. This is the commonest of the genus with us.

S. quadripunctata, Linn. (Plate VI., Fig. 3). Black, with the lateral borders of the pronotum and the wing-cases brownish-yellow, the latter each with a round, black spot in the middle and another at the base. They are common in oak woods in spring, wliere they attack the nests of caterpillars.

* S. opaca, Linn. Upper surface covered with dense sessilc, grey pubescence. The wing-cascs have three raised longitudinal lines. It is said, like the rather larger $S$. atrata, to be sometimes injurious to bect.

* S. obscura, Linn. (Platc VI., Fig. 4). Black, slightly shining. The pronotum is scarcely emarginate in front. The wing-cases are regularly punctured, the punctures bcing at regular intervals, and not coalcscing.

* S. atrata, Linn. (Plate VI., Fig. 5). Shining black. The pronotum is slightly concave. The elytia are roughly 
punctured, with three raised, smooth, longitudinal strix. It is a very common species.

Genus Axisotoma, Illig.

Antennæ eleven-jointed, five belonging to the club. The mesosternum is finely and sharply keeled. The hind tarsi have only four joints. Wing-cases punctate-striate. They are mostly small beetles, varying from $1-3 \mathrm{~mm}$. in length, which live in fungi and decaying wood.

* A. cinnamomea, Panz. Elongated, yellowish-brown, with the pronotum bordered at the sides, and widest in the middle. The elytra are uniformly punctate-striate, with an additional row of larger punctures between the strix. Length, 4-5 $\mathrm{mm}$. It is found in fungi, and especially in truflles.

* A. dubia, Illig. Rather flatly convex, pitchy-brown, blackish or reddish-ycllow. The pronotum is closely purictured, and the wing-cases are strongly punctate-striate. Length, $2-3 \mathrm{~mm}$.

\section{FAMILY VIII. SCAPHIDIIDE.}

Boat-shaped, smooth, shining little beetles, which live in fungi and in the decaying stumps of trees. The antennæ are straight and consist of eleven joints, the last five being enlarged. The front coxre are prominent. The number of abdominal segments varies from five to seven.

Genus Scaphidium, Fabr.

Antenna with four or five terminal joints; eyes distinctly emarginate. They live in fungi growing on trees.

* S. quadrimaculatum, Oliv. Shining black, with reddishbrown antenne, with a black club. The wing-cases, which have two red transverse spots, are rather closely punctured. The legs are black with red tarsi. Length, o $\mathrm{mm}$. 


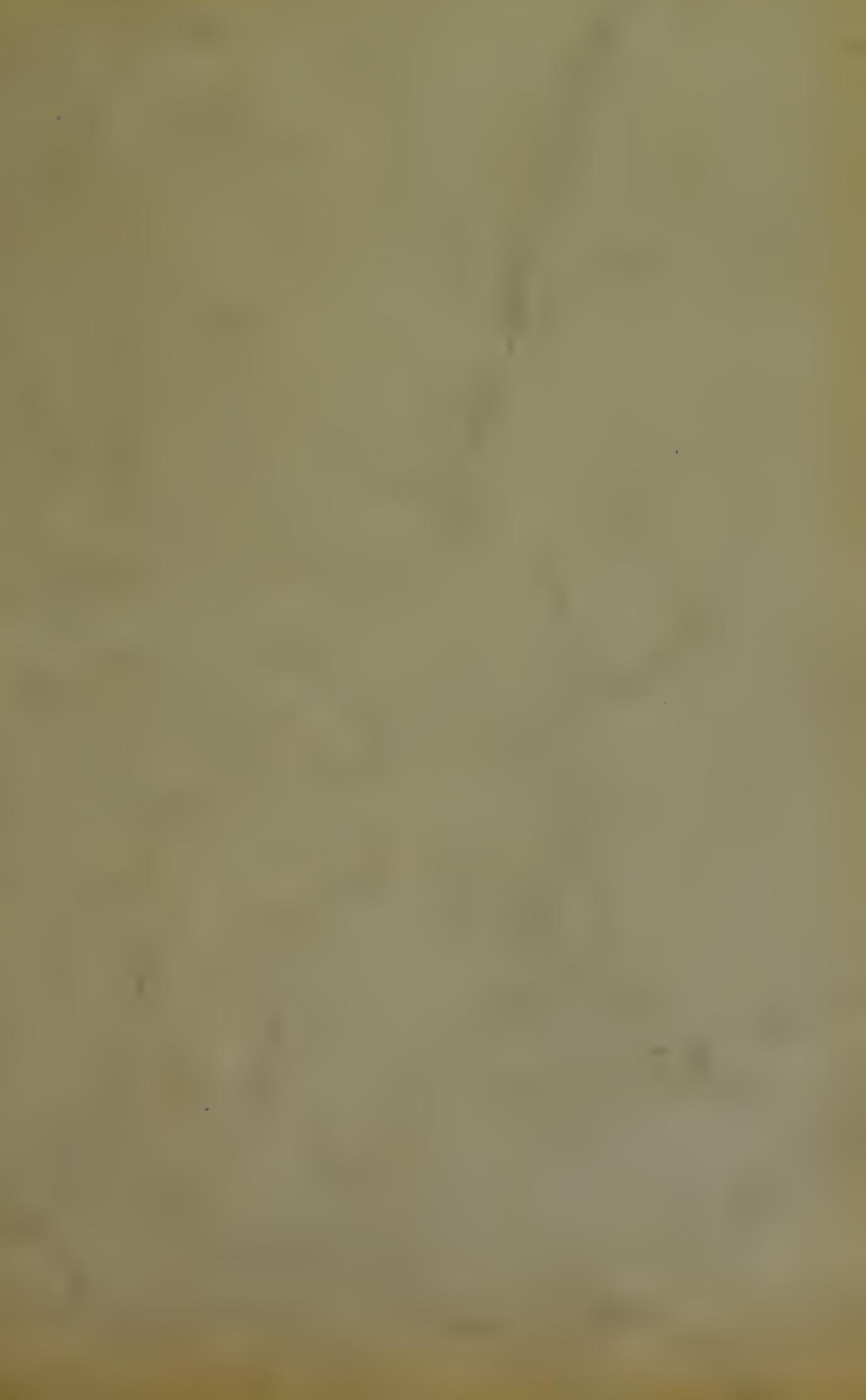



6.

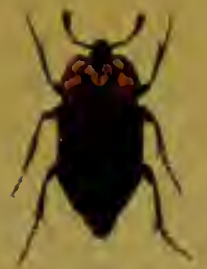

1.

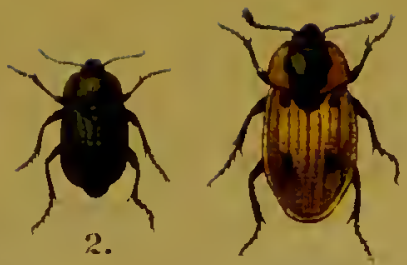

3.

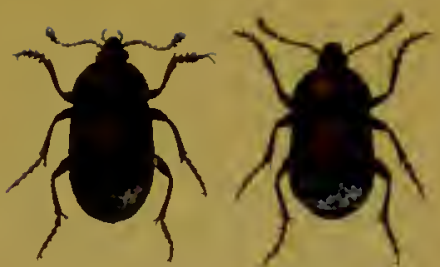

4.

5.

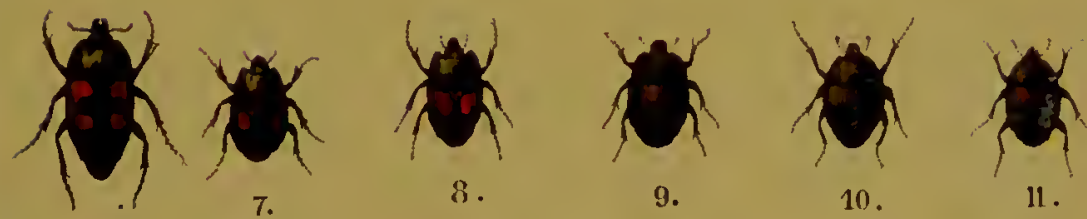

6.

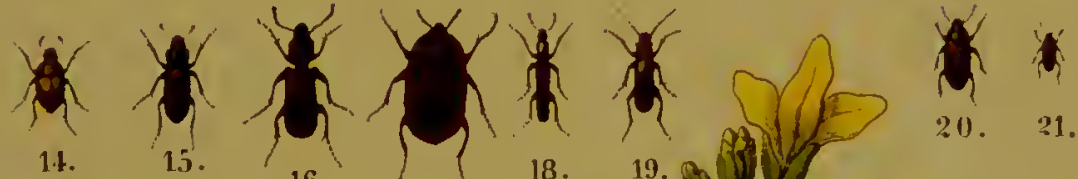
1.4. 15. 16.$)_{17} 18$.

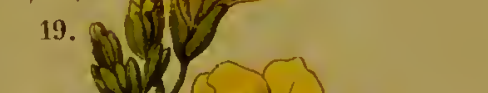

ติ

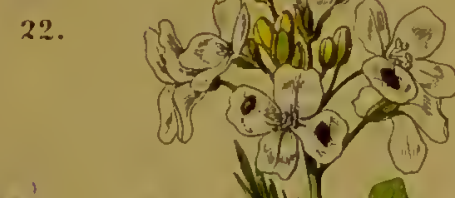

i $\quad 1$

2.5.

$+\quad$

$27 . \quad 28$.

26.

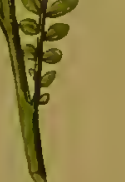

12.
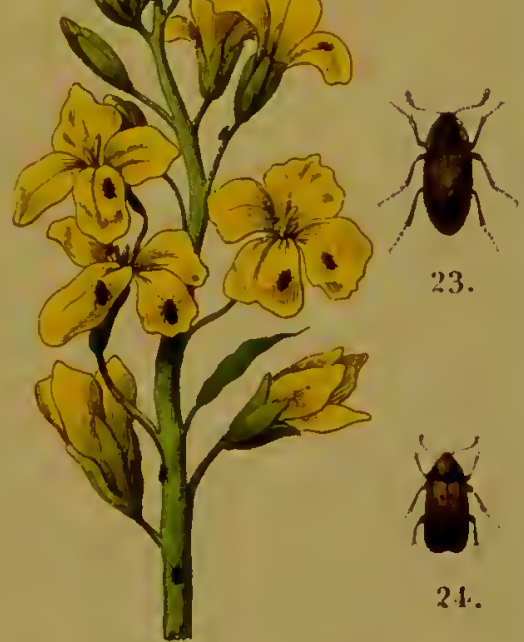

23.

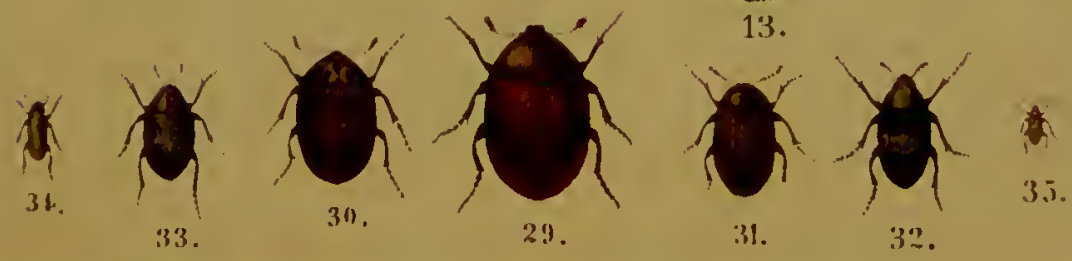





\section{FAMILY IX. HISTERIDE.}

Wing-cases strongly truncated. Legs with flat tibir. retractile into pits. Hind coxæ widely separated. They live in carrion and dung, and beneath the bark of trees, where they prey upon other insects.

\section{Genus Hister, Linn.}

Body somewhat stout; head retractile, and covered beneath by a rounded projection of the prosternum. The flagellum of the antennæ is gradually thickened, with a flattened oval club. The hind tibiæ have two rows of spines on the outer edge. They live in dung, or on carrion, as well as on livingr insects.

* H. quadrimaculatus, Linn. (Plate VI., Fig. 6). Wing-cases with a large, frequently-interrupted, red spot. The front tibix have a simple tooth at the end. It sometimes kills dung-beetles.

H. quadrinotatus, Scrib. (Plate VI., Fig. 7). Smaller than the last species. The spots on the elytra often run together. The tibiæ have three small teeth on the outer margin.

H. fimetarius, Herbst. (Plate VI., Fig. 8). Elytra with a large orange spot, concave behind. The front tibix have four teeth. Length, 6-7 $\mathrm{mm}$. It lives in dry, sandy pastures.

* H. bimaculatus, Linn. Only $4 \mathrm{~mm}$. in length. Antenna and legs brownish-red.

* H. cadaverinus, Illig. (Plate VI., Fig. 9). This species is as large as the foregoing, with similar elytra, but the front tibic: have five or six dentations. It is not rare.

* H. unicolor, Fabr. (Plate VI., Fig. 10). Perfectly black, with the outermost and the two inner strix of the wing-casus strongly truncated. Front tibise with three teetl. Length, $4-5$ mun. Common in cow-dung. 
* H. merdarius, Sturm. Elongated, quadrilateral. The front tibia with three or four teeth. The two inner striæ of the wing-cases are the only ones which are truncated. Length, $5 \mathrm{~mm}$. It is a rare species.

\section{Genus Saprinus, Erichs.}

Upper surface more or less punctured. Prostemum not lobate; head retractile; antennæ filiform, with an elongated first joint and a rounded club. They live in dung, decaying fungi, and carrion.

* S. nitidulus, Fabr. (Plate VI., Fig. 11). Black, with a metallic shine. Wing-cases rather closely punctured, with four striæ only reacling to the middle. It is common in dung, \&c.

* S. coneus, Fabr. This species is only $2-3 \mathrm{~mm}$. long, black, the elytra with a complete sutural stria, which is recurved. The strix on the elytra only reach the middle, and the second is entirely wanting. It is a common insect.

\section{FAMILY X. PHALACRID正.}

Antennæ eleven-jointed, with a club composed of three joints. The front coxæ are globose. The tarsi have five joints, the first three being broad and velvety beneath, and the fourth very small. They are small species, and live in flowers, where the larvæ may also be found. They hibernate under the bark of trees.

\section{Genus Phalacrus, Payk.}

* P. corruscus, Payk. (Plate VI., Fig. 12). This is shortly oval and very convex. The last joint of the maxillary palpi is long and almost cylindrical. It frequents flowers, especially the Composita. 


\section{FAMILY XI. NITIDULIDE.}

Small, flat, and rather broad beetles, with straight antennæ, usually composed of eleven joints, three forming the club. The front coxæ are cylindrieal. The tarsi are five-jointed, some with the first and others with the fourth segment very small. They are all small beetles, and feed on dried animal matter and carrion. Many of them are found upon flowers.

\section{Genus EpUræA, Erichs.}

These are for the most part yellowish-brown species, which live on flowers and on the exuded sap of trees. The antenne converge obliquely inwards towards each other, and the first three joints of the tarsi are expanded, and densely clothed with small hairs beneath.

* E. obsoleta, Fabr. Elongated, of uniform breadth. The wing-cases are ochre-yellow, with one or more spots. The thorax and abdomen are often blackish. It is found under the bark of pine-trees, and on the exuded sap of other trees. Length, $3 \mathrm{~mm}$.

\section{Genus MeLigetires, Kirby.}

Elongated, oval. The hind tibix are ciliated, and the first three joints of the tarsi are expanded and villous beneath. The wing-cases leave the last abdominal segment exposed. They are found on flowers, often in large numbers, and under the bark of trees.

* M. ceneus, Fabr. (Plate VI., Fig. 13). Shining greelı or blue, with the under surface black, and legs pitchy-black. It is one of the commonest beetles living upon flowers, and eats into the bud, where the female deposits her egrgs. The larvie feed upon the flower, and pass through their metamorphoses in 
the ground. The beetle is found in spring and summer, and hibernates. It is very destructive to rape.

\section{Genus Cychrands, Kugel.}

Wing-cases covering the abdomen except the extreme tip. Antennal grooves indistinct. Prosternum with a conical projection towards a groove on the mesosternum. They are found in fuzzballs, and on flowering shrubs, such as hawthornblossom.

- C. luteus, Fabr. (Plate VI., Fig. 14). Reddish or brownishyellow, with yellow pubescence, the hairs being close and sessile. The pronotum and elytra are not punctured nor spotted. It is conumon on flowers.

\section{Gentus IPs, Fabr.}

Elongated little beetles, with slightly abbreviated elytra. The prosternum reaches only a little over the front inargin of the mesosternum. The species live under the bark, and feed upon the sap of trees.

*I. quadripustulata, Fabr. (Plate VI., Fig. 15). Each wingcase with two bright red spots. Antennæ and legs pitchybrown. It frequents frcshly-cut pine-trees, and the larve live under the bark.

\section{FAMILY XII. TROGOSITID尼.}

Body oval or elongated, usually flattened. Antennæ elevenjointed. The first tarsal joint is the smallest. The claws are simple, with a small styliform lobe between them, terminated by two bristles. They are found under the bark of trees, and among drugs.

Genus Trogosita, Oliv.

Body flat and elongated, smooth. Antennæe eleven-jointed, gradually and only slightly thickened towards the extremity. 
Eyes reniform. They are found in rotten wood, under bark, and in bakers' shops, warehouses, \&c.

* T. mauritanica, Linn. (Plate VI., Fig. 16). Pitchy-brown. Wing-cases punctate-striate. The beetles and their larvæ are found among drugs and other merchandise, and have thus been carried over the whole of the globe. They are also found under the bark of decaying forest trees, such as oaks, beeches, and elms.

Genus PeLtis, Geoffr.

Body oval or elongated. Antennæ with a narrow, looselyjointed club. Eyes transverse in some, more rounded in others. Tibie without spurs. They are found inder the bark of trees.

P. ferruginea, Linn. (Plate VI., Fig. 17). This species is. $8-9 \mathrm{~mm}$. in length. Wing-cases with regular rows of punctures, and seven raised longitudinal lines. It is found under the bark of various trees, and also in houses.

\section{FAMILY XIII. COLYDIID无.}

Antennæ with from eight to eleven joints, clnbbed. Tarsi simple, with four joints. Abdomen with five, rarely with six segments, the first three or four being immobile. Front coxæ. globose. They are found under bark, and in fungi growing on. trees.

\section{Genus Ditoma, Illig.}

Body elongated. Antennæ eleven-jointed, not set in pits. The first three joints of the tarsi are ibout equally short. 'They are found under the bark of trees.

* D. crenata, Fabr. Black, with reddish-brown anteunæe and legrs. Wing-cases punctate-striate, with alternate, raised, intermediate spaces, and each with two red spots or bands. Length, 2-3 mm. Local, under the bark of dead trees. 
Genus Colydium, Fabr.

Body slender and linear. Antennæ eleven-jointed, with the two terminal joints largest. Wing-eases with raised strix. They are found under bark.

* C. filiforme, Fabr. (Plate VI., Fig. 18). Shining blaek, with the antennæ, legs, and base of the elytra, rusty-red. The last named are rounded behind, with four distinet, raised, longitudinal strix. It is found in old oaks in the New Forest.

\section{FAMILY XIV. CUCUJID辰.}

Body usually long and flat. Antennæ with eleven joints, filiform, or with three larger terminal joints. Tarsi with five joints, frequently only four on the last pair in the males. They are found under the bark of trees, or in vegetable refuse, and are usually rare.

Genus Brontes, Fabr.

Body flat, with the pronotum mueh broader than long, with projeeting anterior angles. The antennæ are filiform, with eleven joints, the first being long and rather thickened towards the end. The males have longer antenne than the females, and a small erooked projection on the outer border of the maxillæ. They live under the bark of trees.

* B. planatus, Linn., is the only European species. It is elongated, dull blaekish-brown, with slightly striated wingcases, and is found under the bark of many kinds of trees, including oak, beech, \&e. It is very rare in Britain.

Genus Silvanus, Latr.

Antennæ eleven-jointed, with a three-jointed elub. The first three joints of the tarsi are broad, and densely pubescent beneath, the first being as long as the two suceeding ones, 
and the fourth very small and partially hidden under the third. They are found in grass, in corn, and under the bark of trees.

* S. frumentarius, Fabr. Brown, finely pubescent; pronotum with two deep longitudinal furrows. The elytra are regularly punctate-striate. The beetle and larva are frequently met with in warehoused goods, especially in rice. The insect was probably first introduced from America.

\section{FAMILY XV. CRYPTOPHAGID正.}

Abdomen composed of five freely-movable segments, the first of which is the longest. Antennæ with eleven joints, the club being formed of three. The tarsi are generally fivejointed, the hind tarsi with only four joints in the males of many species. They are found in fungi, and in decayed wood.

Genus CRyptophagus, Herbst.

Small elongated beetles, with eleven joints to the antennæ, which are inserted on the sides of the frontal border. The pronotum is crenulated on the sides. The tarsi are composed of five joints, except the hind tarsi of the males, which have only four. They are found in damp, swampy places, in cellars, in tree-fungi, and decayed wood.

*C. lycoperdi, Fabr. Elongated, convex, reddish-brown, or rusty-red. The pronotum has the edges dusky, and the anterior angle very acute; there is a very small tooth in the middle. Length, $2-3 \mathrm{~mm}$. In fungi, and under the mouldy bark of trees.

\section{FAMILY XVI. LATHRIDIID屆.}

Body small; antennæ clubbed; tarsi with three simple joints, the front tarsi rarely with four. The abdomen is formed of five segments. They live under decaying vegretable substances, on mould, and under sweepings. 


\section{Genus Latirridius, Herbst.}

Antennæe formed of eleven joints, with the last three enlarged. The pronotum is sharply ridged on the edges. All the tarsi are thrce-jointed. There are a large number of small species, which live especially on mouldy vegetable matters.

* L. minutus, Linn. Black or blackish-brown, with reddishochreous antennæ and legs. The thorax has two elongated little pits upon it, and the elytra are uniformly and deeply punctate-striate. Its length is $1 \frac{1}{2} \mathrm{~mm}$. It is common in lichens, in houses, and in mouldy substances.

\section{FAMILY XVII. MYCETOPHAGID曆.}

Elliptical, slightly convex, and finely pubescent. Antennæ with eleven joints, gradually thickened, or with two or three larger joints at the end. Tarsi with four joints, except the front ones, which have only three in the males. They are found in fungi growing on trecs, and under bark.

\section{Genus Mrcetophagus, Hellw.}

Eyes obliqne, emarginate in front. Antennæ gradually thickened towards the apex. Body elongated. Pronotum with a dcep depression on each side at the posterior border. The elytra are punctate-striate. They live in tree-fungi.

* M. quadripustulatus, Linn. (Plate VI., Fig. 20). This is an elongated spccies. The first six joints of the autennæ are red. the next four brown, and the terminal onc oval and pointed. The elytra are black with two brick-red spots on each side. It is met with in trec-fungi, and in rotten oaks.

\section{Genus Trрнда, Kirby.}

Body elongated; pronotum with the margins entire. The 
antennie have the last three joints enlarged. The eyes are round.

* T. fumata, Linn., is the only species. It is slightly flattened, rusty-red or rusty-yellow, very closely punctured, with fine sessite, yellow pubescence. The elytra are finely punctate-striate. It is common in the decaying portions of old trees, and is not infrequent in houses.

\section{FAMILY XVIII. DERMESTID压 (Bacon Beetles).}

The antennæ, which are inserted on the front of the head, are short, straight, and usually eleven-jointed, with a club composed usually of three, more rarely of two, or more than three joints. The front coxre are conical, the posterior pair flattened. The tarsi have five joints, and the abdonien is composed of five freely movable segments. Many species frequent flowers, often in large numbers, and the larvæ feed on dead animal substances.

\section{Genus Byturus, Latr.}

There are no ocelli. Antennæe with eleven joints, three forming the club. The second and third joints of the tarsi have lobate appendages, and the fourth is very small, and hidden in the third. They are found on flowers.

* B. fumatus, Fabr. Ełongated, and closely covered with yellowish-grey hair. It is found on flowers, and the larve of this beetle are well known as the whitish worms met with in raspberries, and less commonly in blackberries.

* B. tomentosus, Fabr. (Platc VI., Fig. 22). Is rather smaller than the preceding. It is either black with grey hair and reddish-ochreous legs and antennæ, or pitchy-brown with yellowish-grey hair and orange legs and antenne. It is found on flowers. 


\section{Genus Dermestes, Linn.}

The first four joints of the antennie are short and simple. The claws are simple. The hind coxæ are expanded and flattened. The antenne are formed of eleven joints, the club occupying three. They are long and cylindrical species which live on animal substances. The larvæ have thick erect hair, and are frequently met with in the larder. When touclied, they will fain death.

* D. vulpinus, Fabr. (Plate VI., Fig. 23). This is an elongated, dull black species with reddish-brown antennx. The under surface is covered with dense white hair, and on the sides of the metasternum and of each abdominal segment there is a black spot. It feeds upoin animal substances, and has been introduced into all parts of the globe with the spread of commerce.

* D. lardarius, Linn., the Bacon Beetle (Plate VI., Fig. 24). Elytra with a broad, brownish-grey band. It is rather local, and will attack any kind of animal substances-dried meat, bacon, hides, fur, \&c. It is particularly partial to natural history specimens.

Genus Attagenus, Linn.

Body elongated; antennæ with eleven joints, the last three being enlarged. The front tibiæ liave fine spines on the outer border. They are found on flowers, and feed on the petals as well as on the anther; but they and their larvæ are also particularly destructive to furs.

* A. pellio, Linn. (Plate VI., Fig. 25). This is an oval, black beetle, which has the elytra frequently brown. The upper surface is covered with blackish hair, and the lower with grey silky pubescence. It is met with in winter, particularly 
on furs, the hair of which then comes out in patches; and also in stuffed animals and in natural history collections.

\section{Genus Anthresus, Fabr.}

Numerous small, rotund or shortly oval beetles, usually with eleven joints to the antennæe and with laterally-curved elytra, which are variously markerl with white and yellow seales. The pronotum is expanded behind into a lobe. They live on animal substances, but are also found in large numbers on flowers.

* A. scrophularic, Linn. (Plate Vl., Fig. 26). Antennæ elevenjointed; wing-cases with a red suture and extremity, and with three bands. This species is found on flowers, preferring Umbelliferce; but is also common on furs and in collections of inseets, on the Continent, but is very rare with us.

* A. pimpinelle, Fabr. (Plate VI., Fig. 27). Black above, varied with red and white. The elytra with a broad white band, and two spots of the same colour at the extremity. It is also common on flowers, and swarms in old birds' nests on the Contiuent, but is very rare in Britain.

* A. museorum, Linn., the Museum Beetle (Plate VI., Fig. 28). Antennæ with eight segments, the club being formed of two. It is blackish-brown, sprinkled with rusty-brown. The wing-eases are clothed with grey and orange scales. It is common on flowers in May, and the larvæ are very destructive to collections, especially to those of insects, \&e. The best remedy against these and against mites, is to supply the boxes or cabinet-drawers with naphthaline.

\section{FAMILY XIX. BYRRHID屟.}

Antennæ usually with eleven, rarely with ten joints, gradually thickened, but with several larger terminal joints. The heal prominent or retraeted under the pronotun. The 
front and middle coxie are cylindrical, and the posterior coxæ are flattened, transverse, and approximated. They are very convex beetles, which may be found crawling slowly about sandy roads in the daytime. They feed on moss.

\section{Genus Byrrhus, Linn.}

Hind legs fitting into sharply-defined grooves. All the tarsi fit closely into the tibix. The head is so retractile, that the maxillæ and half the eyes may be covered. The markings on the wing-cases are generally formed of fire velvety hairs, in consequence of which they are very difficult to identify if rubbed. They are found in pastures, in dry sunny places, on roads, and in dry ditches.

B. gigas, Fabr. (Plate VI., Fig. 29). Elytra red or brown, with a short, yellowish-grey, silky pubescence, and a pale, more thickly-pubescent, transverse spot beyond the middle, which is bordered with brownish hairs behind. It is wingless. The third segment of the tarsi is lobate. Length, 12-13 mu. It inhabits the mountains of Eastern Europe.

B. ornatus, Panz. (Plate VI., Fig. 30). This species is also apterous. The elytra have regular, fine, and rather deep longitudinal striæ, which in fresh specimens are marked with black, velvety spots. It inhabits the mountains of Switzerland and Bavaria.

* B. pilula, Linn. (Plate VI., Fig. 31). This insect is provided with wings. The upper surface is brown, with felt-like pubescence, and the finely-striated elytra have dark, velvety spots. It is not uncommon in ruts in May.

* B. fasciatus, Fabr. (Plate VI., Fig. 32). It is winged. The elytra have a yellow waved band, and there are two spots of the same colour on the thorax. It is fairly common in dry, sandy places. 
* B. dorsalis, Falor. (Plate VI., Fig. 33). This species is also winged. The band on the wing-cases is not waved, and the thorax has black markings. It is widely distributed.

\section{FAMILY XX. PARNID正.}

Body elongated, flat, or convex, sometimes partially covered with short, felty hair. Antennæ on the front of the head, usually eleven-jointed. Wing-cases closely contiguous and entirely covering the abdomen. Front coxæ sometimes cylindrical, sometimes globose; the posterior pair almost semi-cylindrical. Tarsi five-jointed, with a large terminal joint. They live in or near running or standing water, where they creep about on plants and stones, but do not swim. They subsist upon decomposing vegetable inatter, and are provided with an air-sac, which enables them to remain for a considerable time under water.

\section{Genus Parncs, Fabr.}

The antennæ have an ear-like form, and the head is retractile in the thorax. Middle and hind legs approximated. The terminal joint of the tarsi with two stout claws. They live in water.

P. viennensis, Heer (Plate VI., Fig. 34). Elytra deeply and irregularly punctured. It is an elongated, rather flat, black beetle, with fine, thick, yellowish-grey, silky pubescence, and longer black hair. It is found in many parts of Central Europe, but not in the British Isles.

\section{Genus ELmis, Latr.}

Body small and oval, either smooth, or with only thin, short hair above. The antemne have eleven joints, and are almost imperceptibly thickened towards the extremity. The head is 
retractile under the prothorax. The scutellum is elongated. They live in running water, like the last genus.

*E. aneus, Müll. Shining black, with the wing-cases dark bronzy, punctate-striate. The thorax is nneven, with raised longitudinal striæ on the sides of the back. Length, $2 \mathrm{~mm}$. It is common in brooks, at the roots of Scrophularia aquatica, in which the larvæ live.

\section{FAMILY XXI. HETEROCERIDA.}

Body rather elongated, pubescent. The head is long. Antemna eleven - jointed, short, the first two points large and triangular, with long hair, and the rest forming a club, serrated on the inner side. The tarsi are four-jointed. The only genus is:

Genus Heterocerus, Fabr.

These beetles live in mud or sand on the margins of streams and lakes, and if the ground be pressed together with the hand or foot they will come out of the holes which they lave dug.

* H. lavigatus, Panz. (Plate VI., Fig. 35). This is an elongated, somewhat flat, black beetle, with fine grey pubescence. The legs are pale yellow; the base of the femora, the knees, and ends of the tibix, blackish. The wing-cases are thickly punctured with yellowish stripes and spots. Local.

* H. marginatus, Fabr. This is a rather convex black species, with fine brown hair. The lateral border of the pronotum, which is finely punctured, is yellow. The elytra have traces. of rusty-yellow spots at the base, and a curved rusty-yellow spot on the shoulders. Length, $3-5 \mathrm{~nm}$. It is generally found gregariously. Local, but fairly common near the coast. 
FAMILY XXII. LUCANID $\mathbb{E}$ (Stag Beetles).

Mandibles sometimes large and projecting like antlers. Antennæ elbowed, and fitting into excavations on the sides of the head. The basal joint is long, and there are several pectinated or serrated immovable joints at the end. The abdomen has five segments. These imposing beetles fly about chiefly at night, and feed upon the exuding sap of trees. The larvæ, which are maggot-like, live on old decaying trees, and often require from two to three years for their transformations.

\section{Genus Lucanus, Linn.}

Pronotum separated from the elytra by a small interval. The sixth abdominal segment is not visible. The antennie have four expanded terminal joints, pectinated on the inner side. The labrum is narrow and curved down between the maxillæ. The latter are large, and in the males much longer than the head, but shorter in the females. The border of the head is produced half across the eyes.

* L. cervus, Linn., the Stag Beetle (Plate VII., Fig. 1, male; Fig. 2, female). This well-known beetle is very variable in size, and some specinens are only half as large as others, probably owing to the larvæ having obtained inferior of insufficient nourishment. The larvæ live in old rotteu oak trees, and are most common in the southern counties. The larva takes five years to complete its netamorplosis.

\section{Genus Platycerds, Geoff.}

The sixth abdominal segment is visible, and the eyes are not excavater. The only species is :

P. caraboides, Linn. (Plate VII., Fig. 3). This varies much in colour, and may be green, violet, blue, or black, darker 
leneath. The larva lives in oak, pine, and beech, and the beetle is already formed in the autumn. It remains, however in its pupa-case during the whole of the winter. In the spring; it feeds on the buds of trees.

\section{Genus Dorcus, MacLeay.}

Sixth abdominal segment not visible. The eyes are almos; divided by the frontal border. The inner lobes of the mandibles have a horny tubercle in the females. They frequent woods.

* D. parallelopipedus, Linn. (Plate VII., Fig. 4). This species is dull black, with the head and pronotuin finely and sparingly punctured. The larvæ live in old decaying beech and walnut trees.

Genus Sinodendron, Fabr.

Thorax fitting closely to the base of the elytra. Antennx short, with three joints to the club. The maxilla are short and do not project. The body is cylindrical.

* S. cylindricum, Fabr. (Plate VII., Fig. 5). Shining black, with the elytra sometimes brownish and the abdomen not infrequently browll. The pronotum has the angles rounded off with tive teeth in the males, and in the female it is only indented in front, and slightly toothed. The horn on the head is small and straight in the female, but long and recurved in the male. The larva lives in the rotting trunks of trees, especially the beech.

\section{FamiLY XXIII.}

\section{SCARABEIDEE Or LAMELLICORNES (Chafers).}

Antennæ short, with from seven to eleven joints, the first being large, and the last joints being expanded and forming a lamellated club. The legs are formed for digging. This is a 



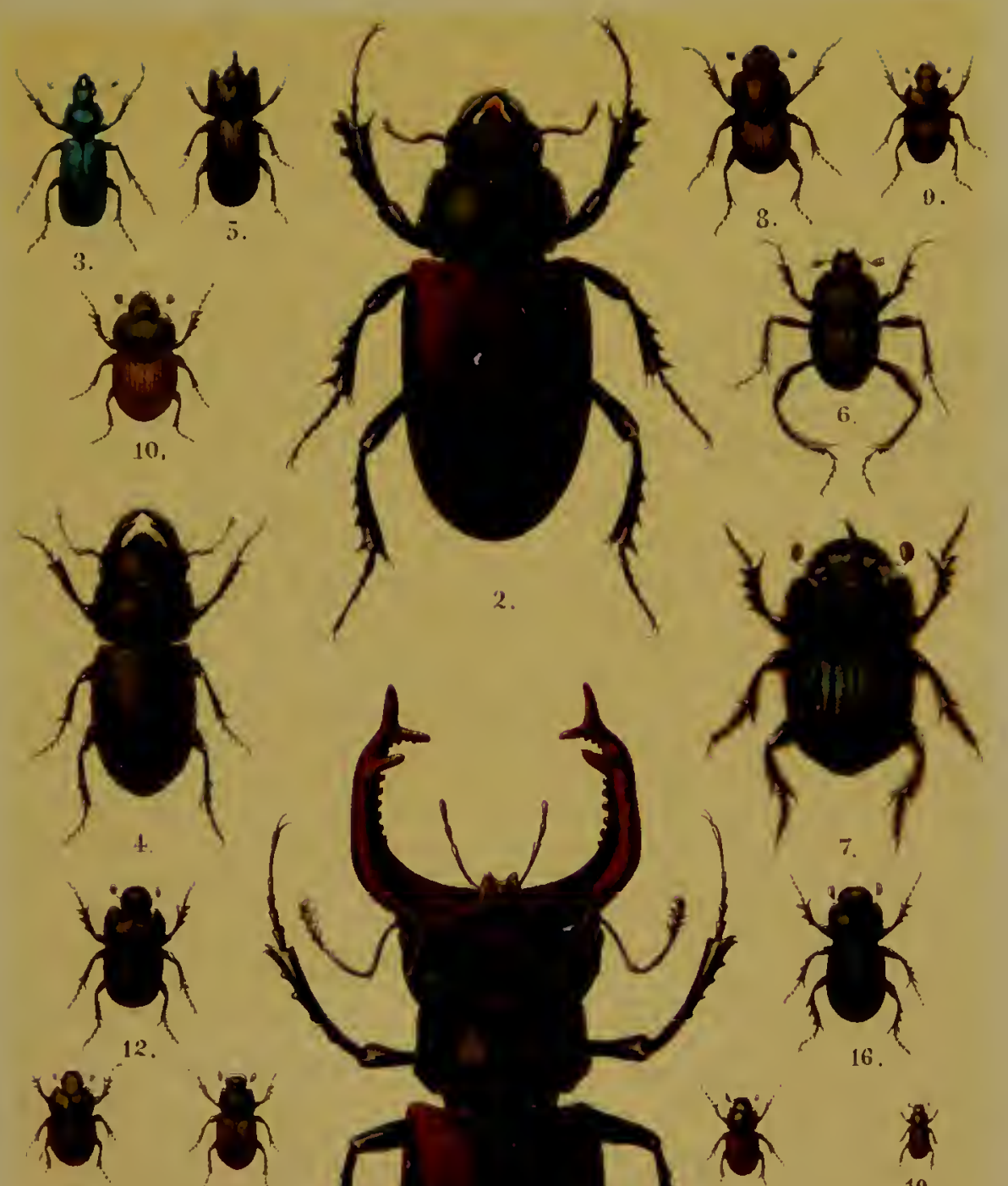

11.

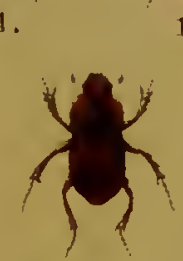

k

15.
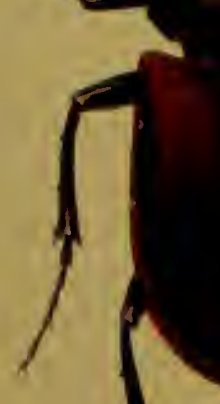

10

18.

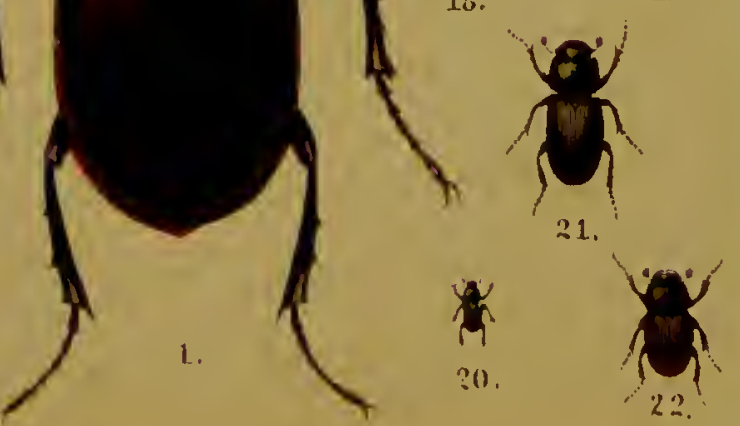

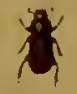

19. 

large family, remarkable for beauty and richness of colouring, and is divisible into several easily distinguishable groups.

\section{Group I. COPROPHINI (Dung Beetles).}

The terminal club of the antennæe has from three to seven movable plates, and the labrum is prominent. The elytra completely cover the abdomen. These bectles generally live in dung, and their larvæ are often found very deep in the ground.

Genus Sisyphus, Latr.

Body rounded; antenna eight-jointed, with an almost oval club; pronotum large, with a border behind, closely approximated to the base of the elytra. Elytra almost triangular. Scutellum not visible. The front legs are rather small, and the hind ones long.

S. schacfferi, Linn. (Plate VII., Fig. 6). Black, with reddishbrown palpi, and brown antennæ, with a blackish club. They frequent pastures, living in the dung of cows and sheep, which they make into round balls in which the female lays its eggs. These it rolls away to a suitable place. It is found in various parts of Central Europe.

\section{Genus Copris, Geoff.}

Antennæ with nine joints. Clypens deeply notched in front. Eyes incomplctely divided. Scutellum not visible. Front tibia with three or four teeth on the outer side, hind tibie distinctly thicker towards the extremity. The only species found with us is:

* C. lunaris, Linn. (Plate VII., Fig. 7). Shining black, the male with a long, slightly recurved horn on the hend, and the fcmale with a short horn, notched at the apex. The suallest, male specimens can scarcely be distinguished from the fenilte, 
except by the horu. It is found in pastures in fresh cowdung, but is somewhat local.

\section{Genus Oxthophagus, Latr.}

Clypeus slightly notched or entire. Antennæ with nine joints. Tarsi filiform, the first joint being long. The rather numerous globose species are often met with in large numbers on dung, which they form into elongated masses of the size of acorns, lay their eggs in them, and bury them more or less coinpletely in the ground. The metamorphosis occupies three months.

* O. taurus, Linn. (Plate VII., Fig. 8). Pronotum bordered at the base, without excavations for the antennie. The male has two long curved horns on the head, which are bent towards one another. The beetle is black, not infrequently brownish, or yellowish-brown. It frequents woods, and feeds on dung but is very rare.

* O. nutans, Fabr. (Plate VII,, Fig. 9). This species resembles the last. The male has a horn, which is curved forwards, and the female has two transverse ridgcs. The clypeus is rounded in front. The thorax is very thickly and coarsely punctured, with a deep notch in front, and with two small projections on the upper margin of the notch in the female and in the smaller male specimens. The elytra are faintly punctate-striate. It is found in the dung of cattle.

* O. vacca, Linn. (Plate VII., Fig. 10). Head and pronotum shining greenish. Elytra reddish-ycllow, finely punctured with grecnish. The horn of the male is much broader at the base than in the last species. The female lias no horns on the posterior occipital ridgc. The smaller male specimens have in the middle of the concavity, on the front of the pronotum, two slight and often hardly perccptiblc clevations. 
O. nuchicornis, Linn. (I'late VII., Fig. 11). I'ronotun entirely black. Wing-cases brownish-yellow, sprinkled with black. The horn on the head of the male is acute and erect. The female has two stout transverse ridges and an elevation in the middle of the pronotum. The smaller male specimens have often only two slight elevations on the pronotnm, and a short horn, or only an obtuse elcvation on the front of the head. It is the commonest of the genus found with us.

O. camelus, Fabr. (Plate VII., Fig. 12). Black and hairy, with two distinct transverse ridges on the head, the posterior of which terminates in two horns in the male. The pronotum has four elevations in both sexes. It is found in the dung of cattle from April to September, and inhabits the cast of Central Europe.

O. (Laccobius) schreberi, Linn. (Plate VII., Fig. 13). Black and shining. The elytra are slightly ridged and striated, with four red spots. The legs are also red. The pronotum is margined at the base, with rounded cavities on the lower surface to receive the clubs of the antenne. It is common in many parts of the Continent, but is not found in Britain.

\section{Genus Oniticellus, Lep. and Serv.}

Body elongated, oval. Antennæ with eight joints. The clypeus is not emarginate in front. The cyes are completely divided into two. The scutellum is small, but distinct above. The pronotum is large and circular, and is broader than the narrow wing-cases. The front tibice have four teeth on the outer side. Their habits are the same as those of the last genus.

O. flaripes, Fabr. (Plate VII., Fig. 14). This is a long, depressed, yellow bectle, with the wing-cases, sternum, and abdoinen, clouded with brown. The middle of the pronotum 
and the head are bronzy-green. The lateral border of the pronotum has a deep cavity on each side. The margins are yellow. It is common in Central and Southern Europe in the dung of cattle, but is not a British species.

\section{Genus Aphodius.}

Body elongated, elytra covering the whole of the abdomen; head flat. The antennie are nine-jointed; and the hind tibix have two terminal spines. They live principally in dung, but a few live in rich mould. The fernales do not form balls of dung, and do not excavate passages, but lay their eggs simply in the dung, into which the larve eat their way.

* A. crraticus, Linn. (Plate VII., Fig. 15). Black, with dirty yellow wing-cases, in the middle of which there is often a dull, blackish-brown spot. The clypeus is black and semicircular, and is distinctly margined at the base. The legs are red. It is not uncommon.

* A. fossor, Linn. (Plate VII., Fig. 16). This is an elongated and very convex black beetle. It is unmistakable on account of its size. The wing-cases are black or reddish-brown. It is comnion in cow-dung.

* A. hamorhoidalis, Linn. (Plate VII., Fig. 17). Shining black, with the elytra strongly punctate-striate, blood-red at the apex, and often in front. It is not uncommon in cow-dung.

* A. fimetarius, Linn. (Plate VII., Fig. 18). Elytra red, punctate-striate. Antenuæ red, with a rusty-yellow club. The pronotum has the whole of the lateral border red. The head has three distinct frontal prominences, witl a curved line in front of them, which is distinct in the male, but not well marked in the female. It is a comnon species.

* A. inquinatus, Fabr. (Plate VII., Fig. 19). Wing-cases greyish-yellow, with darker markings. The scutellun and 
pronotun are sometimes quite black, but are more commonly reddish-brown on the front angles, and rarely along the whole of the sides. The flagellum of the antenna is blackish-brown. The metasternum of the male has a shallow, hairy depression in the middle. The legs are reddish-brown, with the femora yellow beneath. It is comnon everywhere.

* A. sticticus, Panz. Rather smaller than the last species, but very similar. The antennre are, however, yellow, with a brownish club; the mesosternum is not keeled, and the pronotum has a.brownish-yellow lateral stripe, each with a distinct brown dot in the middle. The end of the abdomen is light reddish-brown, and the legs are yellow, with light reddish-brown femora.

* A. merdarius, Fabr. Wing-cases clay-coloured, with the suture black, and the lateral margins fuscous. The legs are brown, with the terminal spines of the front tibire curved in the male, straight in the female. Length, 3-4 $\mathrm{mm}$. It is common in dung.

* A. quadrimaculatus, Linn. (Plate VII., Fig. 20). Elytra punctate-striate, black, with four red spots. Legs black, with reddish-brown tarsi, more rarely brown or reddish. Rare.

* A. prodromus, Brahm. Wing-cases greyish-yellow, each with a large clouded spot, narrowed in front. The pronotum is black, with orange borders. The male has smooth wingcases, but those of the female are hairy. Length, $7 \mathrm{~mm}$. It is a common and very variable species.

* A. rufipes, Linn. (Plate VII., Fig. 21). This is the largest species except $A$. fossor. It is black, with the hind border of the pronotum, the middle of the metasternum, the extremity of the alxlomen, the flagellum of the antemnx and the legrs, ycllow. It is not uncummon. 
* A. luridns, Payk. (Plate VII., Fig. 22). Wing-cases with short, scattered hairs towards the end, sometimes dirty greyishyellow or black, with yellow lines and streaks, and occasionally uniform black. The tarsi are reddish-brown. It is common in spring.

* A. arenarius, Oliv. Shiniug black, occasionally brown. Head witlout protuberances. Wing-cases light or dark brown, obliquely excavated towards the suture at the extreme point. Antennæe and palpi orange, tarsi reddish-brown. Leugth, 2-3 mm. It is local in chalky and sandy places.

\section{Genus Odont жus, Klug.}

Body short, oval. Antennæ eleven-jointed, with an almost round trilobate club. Maxillæe dentated at the extremity. Mandibles with two horny lobes, the outer being somewhat triangular, and the inner having two simple horny hooks. The eyes are completely divided by the margin of the head. The middle legs are close together. The head has two protuberances in the males, and the pronotum two liorns. They are found in dung. The only British species is:

* O. mobilicornis, Fabr. (Plate VIII., Fig. 1). This is dark brown or yellowish-brown above, with orange legs and antennx. The head and pronotum are more strongly punctured in the female than in the male, with indistinct elevations. It is found in the south of England, but is very rare.

\section{Genus Geoticpes, Latr.}

Body oval and generally convex. Antennæ with eleven joints, the first being long, set with single long hairs. The club is oval, trilobate, the lobes being almost completely separated, with the middle lobe sometimes half enclosed between the othels. The ejes are quite divided by the 


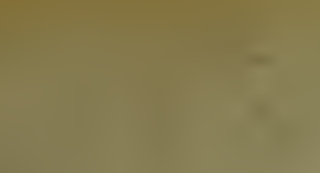

i

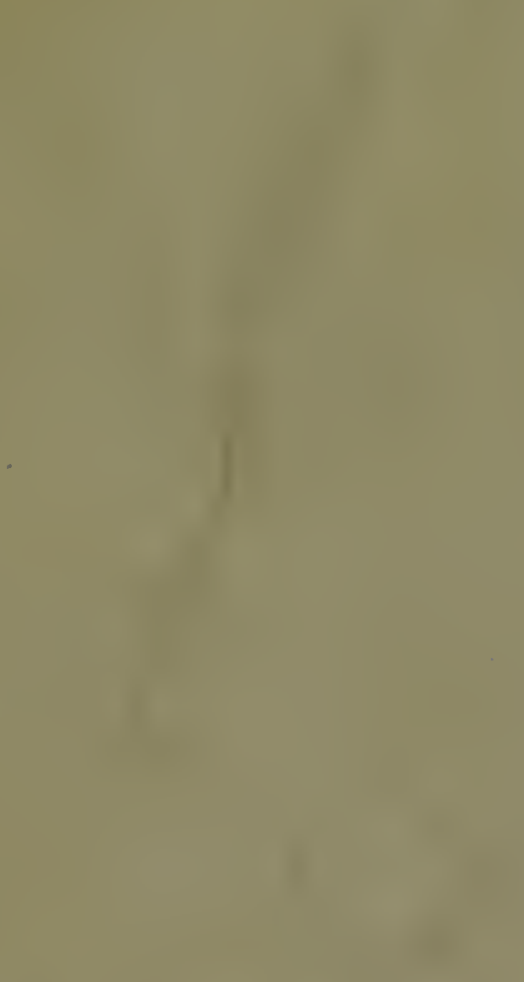

.

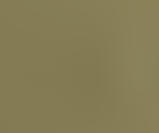

1)

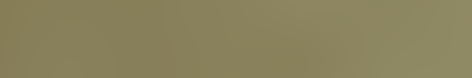

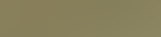

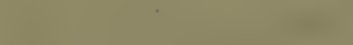

i

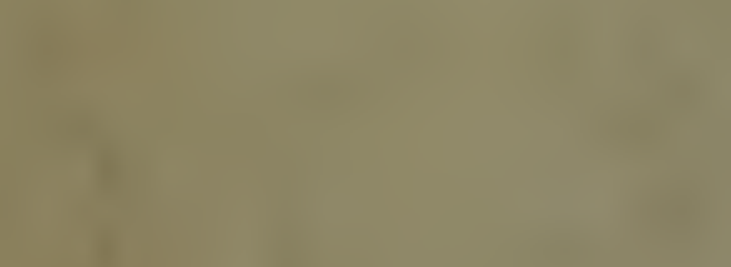

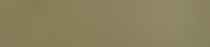

(1) 10 


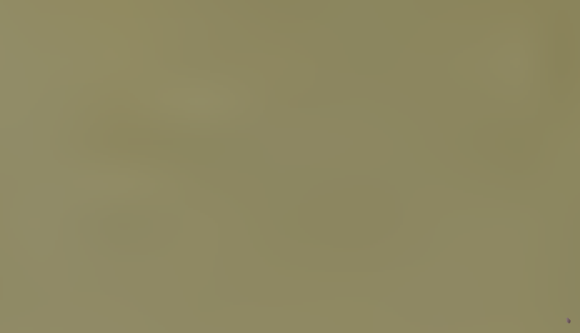

-

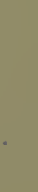

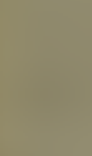

tin

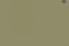
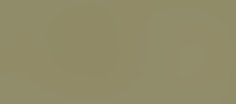

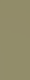

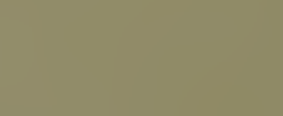

$\rightarrow$
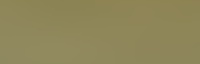

-
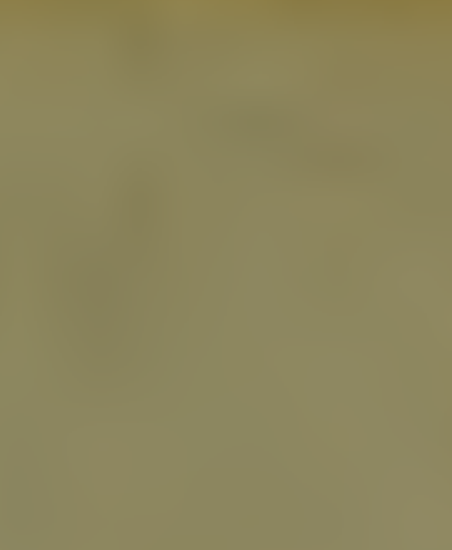

(1)

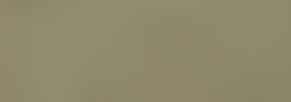

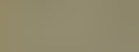
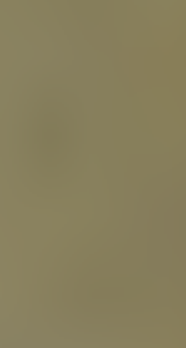

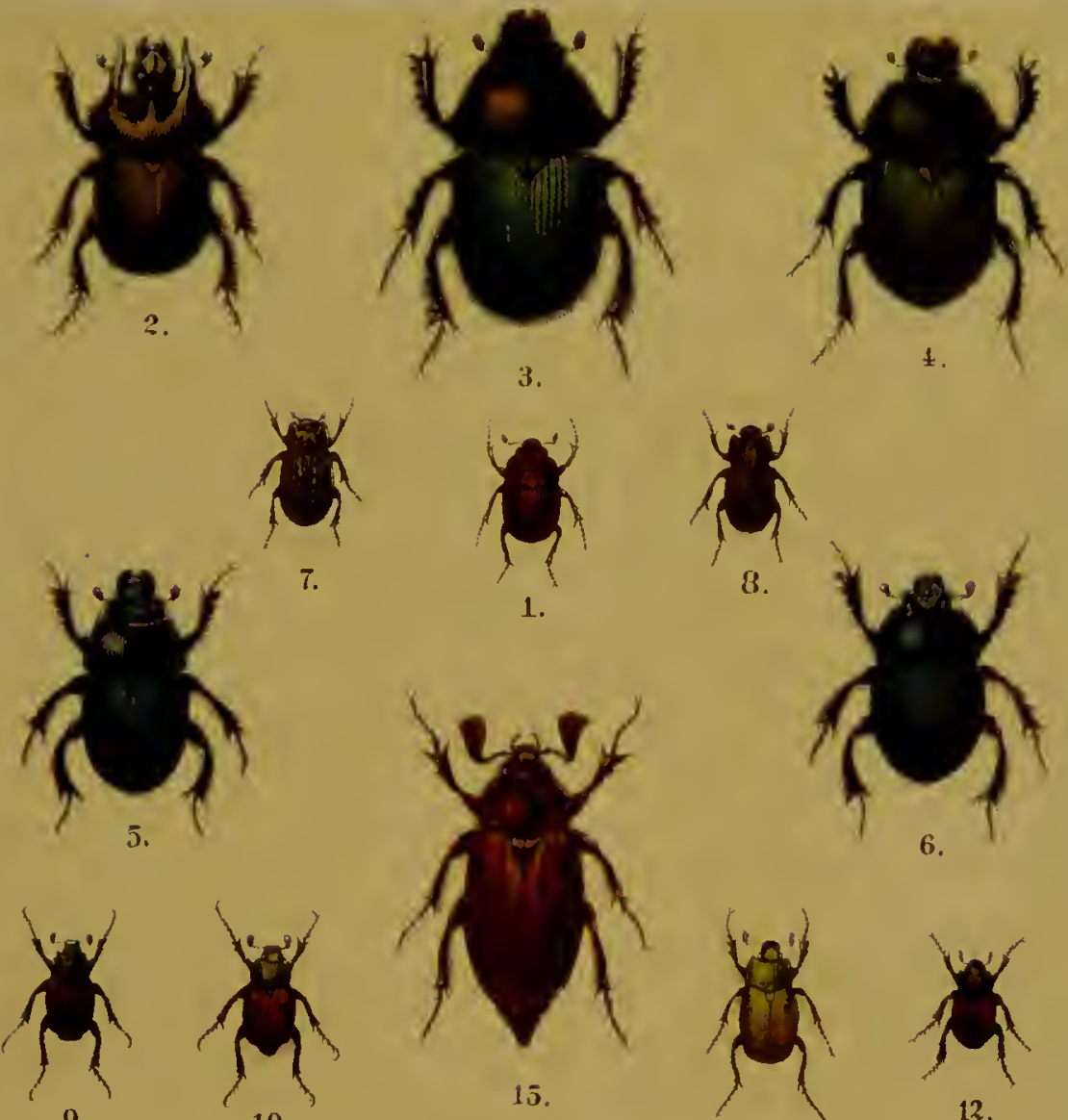

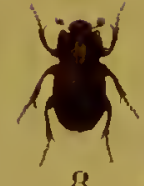

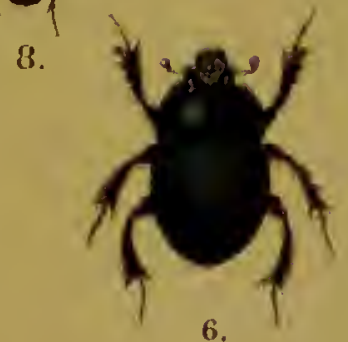

9.

10.

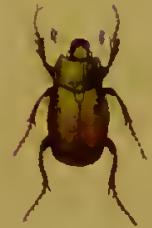

11.

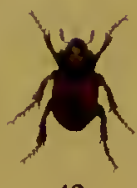

12.
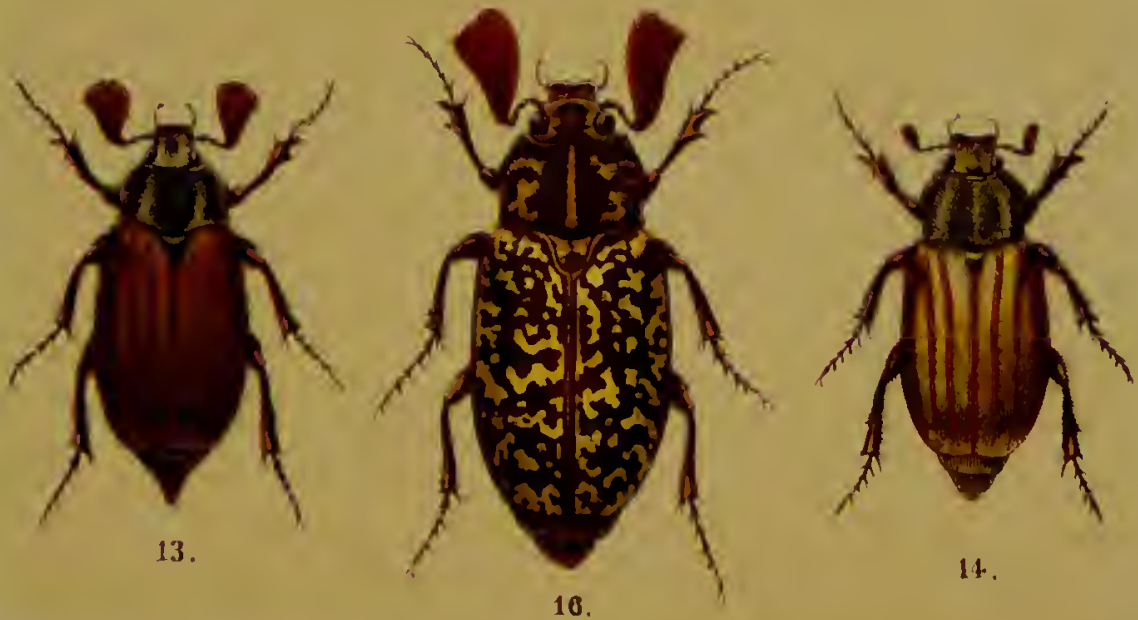

14. 

margin of the liead. The pronotum is only occasionally armed with horns or projections. The species are common in dung.

* G. typhous, Linn. (Plate VIII., Fig. 2). Rather depressed; shining black. Pronotum with three horns in the male, which are directed forwards, and a long transverse ridge in the middle in the female, and very short, lateral horns. It is found in woods in May. It feeds on the dung of horses and cattle, in which it digs round holes and lays its eggs therein.

* G. stercorarius, Fabr. (Plate VIII., Fig. 3). Black, green, or steel-blue; violet-blue beneath. Each wing-case lias fourteen fine, punctured strix, with the interstices scarcely convex. The maxillæ have the external border margined, and twice deeply concave at the apex. It is found in horsedung, but is not so common as the last species.

- G. mutator, Marsh (Plate VIII., Fig. 4). This species closely resembles the last both in size and colour, but has eighteen punctured striæ on the wing-cases. The under surface has a green shine, and not infrequently is fine golden green. It is common, and generally distributed.

* G. sylvaticus, Panz. (Plate VIII., Fig. 5). Convex, blackishgreen above, rarely with a blue shine; blue beneath. The pronotum is completely margined at the base. The elytra are slightly striated, with the intcrstices finely granular. It is common in woods, in dung and fungi.

* G. vornalis, Linn. (Plate VIII., Fig. 6). This species is almost hemispherical. It is black above, with a rich blue, grecn, or violet shine, and blue beneath. The pronotum is only margined in the middle at the base. The elytra are very finely and indistinctly punctate-striate. It is found on horse-dung in early spring, but is somewhat local. 


\section{Genus Trox, Fabr.}

Wing-cases uneven, with small protuberances, or tufts of hair, arranged in rows. Antennæ short. The pronotum is uneven, and fringed on the lateral and posterior borders. The abdomen has five abdominal segments. They live on dry bones, hoofs, and other animal remains, and are able to produce a chirping noise by rubbing the abdomen against the wing-cases.

* T. sabulosus, Linn. (Plate VIII., Fig. 7). Black, and broadly convex. The elytra have four rows of hair-tufts, and four fine strix in the intervals, which are placed in two rows and strongly granulated transversely. It is found in dry, sandy places, in sweepings, among the hair of hides, and on old bones.

* T. scabcr, Linn. (Plate VIII., Fig. 8). Dull blackish-grey, with the elytra only slightly expanded behind, moderately convex, distinctly striated with very small, and also with larger, tufts of rusty-red hair.

\section{Group II. MELOLONTHINI (Cockchafers).}

Antennæ with from seven to ten joints, ending in a fan, which is usually larger in the males than in the females. The clypeus is divided by a suture from the front. The claws are either equal, or else the hind tarsi have only one claw. These beetles live on plants and flowers, and many species appear occasionally in very large numbers, and may then do a considerable amount of damage to trees and plants, on the roots of which the larvæ feed.

\section{Genus Hoplia, Illig.}

Body generally covered with shining scales. Antennæ with nine or ten joints and a trilobate fan. The front tarsi 
have two unequal claws, but the hind tarsi have only one claw. The front tibice are armed with two or three teeth. They all live on flowers, especially on Umbelliferce.

* H. philanthus, Sulz. (Plate VIII., Fig. 9). Male sometimes with brown elytra, female with the elytra reddish-brown, and eovered like the head and pronotum with grey and bluish seales. It appears in June and July on alders and willows, and is particularly partial to Spircea. Loeal.

H. praticola, Duft. (Plate VIII., Fig. 10). Black or brownish, with dark brown or orange-coloured legs. The upper surface is rather thickly covered with scales in the female, mure sparsely in the male. The head and pronotum are somewhat densely clothed with long, erect, rusty-red hair. It is a native of Southern, and the southern parts of Central Europe, where it is met with in swarms in the fields at the end of May.

H. farinosa, Linn. (Plate VIII., Fig. 11). Blaek, with greenish scales above, and sinall sessile tufts of hair scattered about. The antennæe have nine joints in both sexes. The front tibire have two teeth in the male, and three in the female. It is abundant in Southern Europe on Spircea and on umbelliferous plants, \&e.

\section{Genus Homaloplia, Steph.}

Front tarsi scarcely longer than the tibiæ, hind tibiæ long and slender. Antenux with nine joints and a trilobate extremity. The fan of the antennx, and the tarsi are only slightly longer in the males than in the females. The only British species is:

* H. ruricola, Fabr. (I'late VIII., Fig. 12). Deep black, with a greyish-yellow pubescence whieh is replaeed by black on the 
head and pronotum in the male. The elytra are dark orange, and have all the wuargins bordered with blaek; they may also be blaek with a yellow spot on the shoulder, and are rarely entirely black. It may be found in the daytime on flowers during the summer. It is very loeal with us.

\section{Genus Serica, MaeLeay.}

All the tarsi are elongated, and longer than the tibix. The antennæe have nine or ten joints, and a trilobate extremity. The hind coxæ are broad and plate-like, and eover the first two segments of the abdomen more or less eompletely. The tarsi, and fan of the antennæe are longer in the males than in the females. They Hy by night.

* S. brunnea, Linn. This is the only British representative of the genus. It is elongated, eonvex, reddish-oeherous. The wing-eases are slightly grooved, the grooves being punetured. The antennæ have nine joints. The pronotum is twice as broad as it is long, with rather eoarse, seattered punetures on the upper surfice. It is found on grass, in pine and other woods, in June and July, and is rather loeal in England.

Genus Melolontha, Fabr.

Antennæ with tell joints, the third being elongated. The fau is seven-lobed in the males, and rather large and six-lobed in the females. The elytra are brown, with three raised ridges. The abdomen is produeed into a shorter or longer point. They live on trees, and often appear in large numbers.

* Mr. vulgaris, Limn., the Common Cockchafer (Plate VIII., Fig. 13). End of the abdomen broadly elongated, spade-like. Pronotnm blaek, more rarely reddish-brown. The beetle appears in April and May in warm loealities in three years, and in eold places in four, in great abundanee, and is very 
destructive to trees, especially those standing in clearings. The larvæ live on the roots of plants, and do not pupate for three or four years; those pupæ which have developed in thewinter wait for a warm day to emerge.

M. pectoralis, Fabr. (Plate VIII., Fig. 14). Abdominal point narrow in the male, tapering gradually; very short. in the female. The antennæ, legs, and elytra, are reddishochreous. The pubescence is similar to that of $M$. vulyaris. The variety albida, Erichs., with its wingcases dusted with white, is distinguished from the variety of M. vulgaris, which is also dusted with white, by thedifferent tip of the abdomen. It is a native of Austria and Hungary.

* M. hippocastani, Linn. (Plate VIII., Fig. 15). End of the abdomen short, pointed, and abruptly truncated. I'ronotum generally red. It agrees very nearly with $M$. vulgaris in habits, \&c., but is a little earlier in time of appearance. It is. very local, and is said not to occur south of the lake district.

\section{Genus Polyphylia, Harris.}

Elytra smooth, brown, sprinkled with white. The fan of the antennæ is very large in the males, and consists of seven lobes, but is sinall in the females and five-lobed.

P. fullo, Linn. (Plate VIII., Fig. 16). Darker or lighter brown, sometimes nearly black. The elytra are thickly covered with white scale-like hair. The sternum is covered with thick, shaggy, grey hair, and the abdomen with a short, thick, sessile felt. It is local on the Continent, but is coinmon in many sandy localitios. It is found in abundance in woods in July, especially on firs. The larva feeds on the roots of grass. It is not found in the British Isles. 


\section{Genus RHizotrogus, Latr.}

Extremity of the abdomen not produced. Antennæ with nine or ten joints, the third and fourth being of about equal size, with a trilobed club, longest in the males. The tarsal joints lave a row of short bristles below. The beetles remain hidden at the roots of moss, and fly by night.

* R. solstitialis, Linn. (Plate IX., Fig. 1). Wing-cases dark brown, with grey pubescence and three black stripes. The pygidium is finely granular, sometimes brown, with two elongated yellow spots; sometimcs yellow, with a central brown stripe. The antennæ have nine joints. It appcars in June or July, commencing to fly at scven in the evening, and is most destructive in those years when cockchafers are abundant, as it follows up their ravages. The larvæ live in the same way as those of the cockcliafer, but are smaller, and difficult to distinguish from the half-grown white worms. It is somewhat local.

R. fuscus, Scop. (ater, Herbst) (Plate IX., Fig. 2). This is elongated and convex; the male shining black, with reddishbrown antennæ, dark brown elytra, and long, erect, yellowishgrey hair on the head and pronoturn. The female is more convex, orange, with pale yellow elytra, and short hair on the head and pronotum. It is a native of Southern Europe, and begins to fly at from eight to ten o'clock at night.

R. cestivus, Oliv. (Plate IX., Fig. 3). Elongated, oval, slightily convex, reddish-ochreous. The margin of the pronotum and a broad stripe along the suture, or sometimes the entire elytra, are darker. The legs are palc ycllowish-brown. The sternum is covered with shaggy hair, and the abdomen is very sparsely clothed, being often almost naked. The hind fomora and the abdomen of the male are bristly. The antennic have 



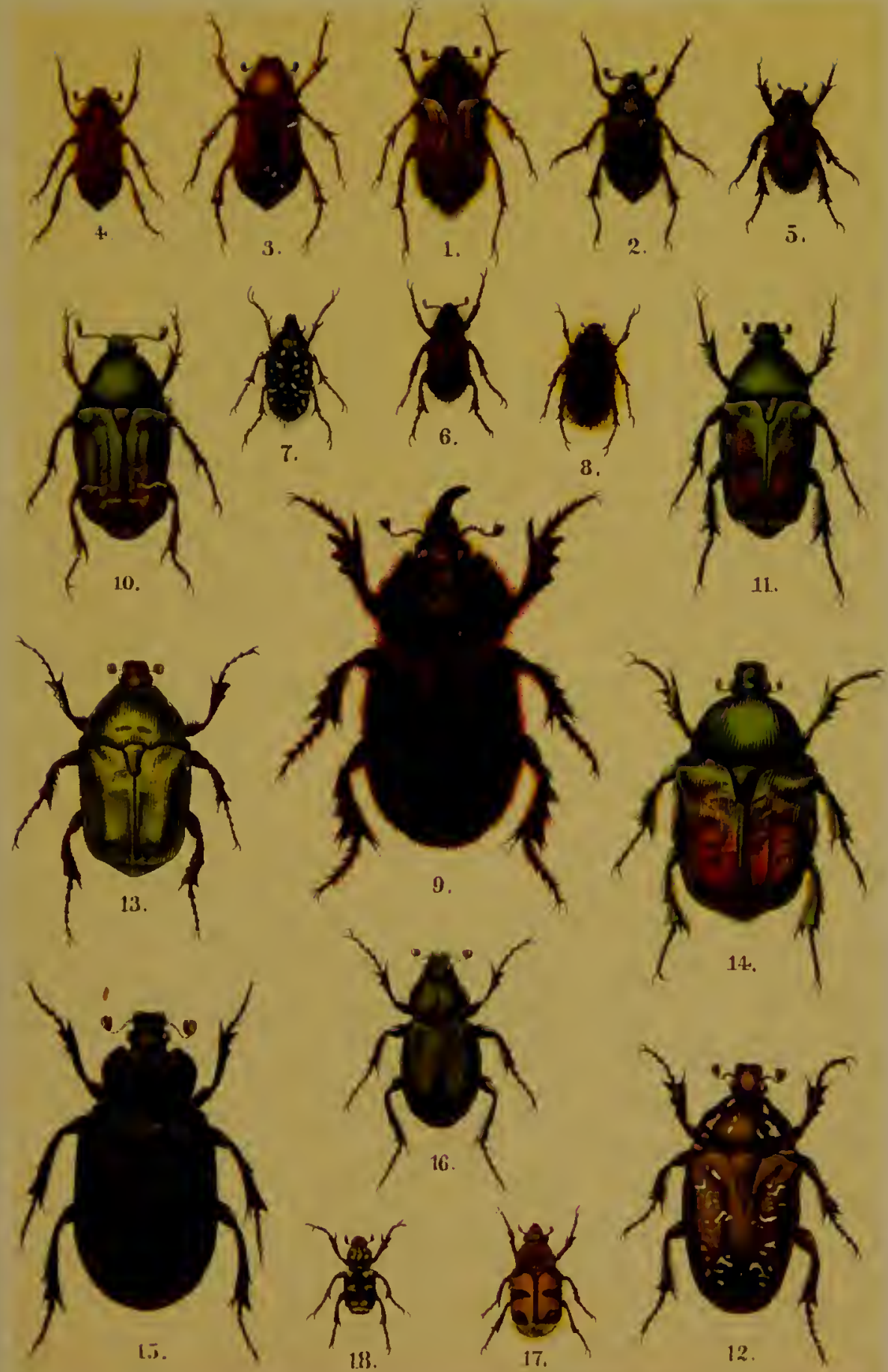

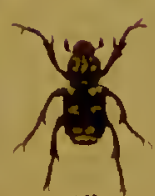

18.
10

17.

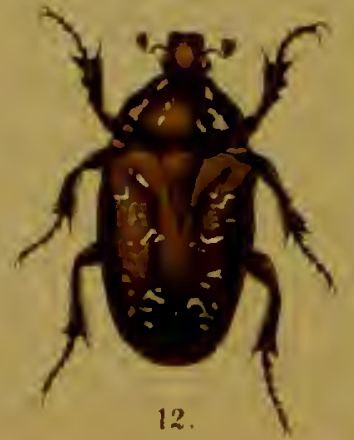



ten joints. It is found in various parts of Europe, but not in Britain. It flies in the evening in April and May.

R. assimilis, Herust (Plate IX., Fig. 4). Elongated, almost cylindrical, orange-coloured or reddish-brown, sometimes with light yellow, at other times with dark brown wing-cases, each having three generally very indistinct raised, longitudinal striæ. The abdomen is covered with very fine yellow pubescence. It is a Southern European species, which flies about on June evenings, especially in dry meadows near woods.

\section{Group III. RUTELINI.}

Claws of the tarsi unequal. Antennæ nine-jointed, with a trilobed club. Clypeus separated from the front by a fine suture. There are six abdominal segments. The elytra do not reach to the extremity of the abdomen. They are moderate-sized beetles, which live on flowers and leaves, and frequently occur in large numbers.

\section{Genus Anisoplia, Serv.}

Body short and flattened. Clypeus gradually narrowed in front, and curved up at the edge. Legs very strong. The claws on the hind tarsi are simple, those of the front ones being larger and cleft on the inuer side. They live on grass, \&c.

* A. agricola, Fabr. (Plate IX., Fig. 5). Somewhat oval, slightly convex, dark metallic-green, with long divergent hair. The head and pronotum are very closely punctured. The elytra are brown, with black markings, sometimes uniform brown or blackish. It is found on corn, of which it ents the flowers.

\section{Genus Phyllopertha, Kirby.}

Clypcus not pointed in front, nor curved up. Hind femora simple, not thickencd. Legs rather weak, with rather large 
cl:iws either on the front and middle tarsi, or on all; they are lificl at the extremity. They live on flowers, and the larvæ in the ground.

* P. horticola, Linn. (Plate IX., Fig. 6). Rather flattened, with black or grey hair. The elytra are reddish-brown, rarely with the suture or the borders darker, pitchy-brown or blucblack. It is black beneath, with denser hair than above. It is common in June and July in fields and gardens.

Genus Anomala, Samouelle.

Body convex. Antenuæ with nine joints and a trilobate clul in both sexes, largest in the males. Hind femora expanded. Hind tibix powerful. The claws of the front and middle tarsi are all simple. The beetles live on leaves.

* A. anea, De Geer (frischii, Fabr.; vitis, Fabr.) Pronotum and elytra variously coloured; green, bluish-green, blue, or yellowish-brown, with a green scutellum. The antennæ are orange-coloured, sometimes with a black club. It is found in sandy places on the coast, and among scrub.

\section{Grove IV. DYNASTINI.}

Front coxæ oblique, enclosed in excavations. Antennæ tenjointed. The males have oftcn horny processes on the head and pronotum.

\section{Genus OrYctes, Illig.}

Maxillæ not toothed; hind tibiæ not dentated at the end. Thicy are large beetles, and mostly exotic.

O. nasicornis, Linn., the Rhinoceros Beetle (I'late IX., Fig. 9). This is one of the two species, which are the only ones found in Europe. The male has a horn of variable length, which curves backwards, and the female has a horny clevation on the clypeus. The pronotum of the former lias a projection 
with three points, and that of the latter a curved ridge. The large stout larvæ of this beetle live in tan, in dung-heaps, and in hollow trees. The beetle flies in the evening. It is found in most of the countries of Southern Europe.

\section{Group V. CETONINI.}

Body more or less flattened. Antennæ with ten joints, the terminal club trilobate. Wing-cases not quite covering the abdomen. Claws simple and equal. There are six abdominal segments, which are longer, or at least as long as the pro- and mesosternum together. They are mostly shining beetles, which live on flowers. The larvæ live in the ground or in rotting plants.

\section{Genus Cetonia, Fabr.}

Body usually naked, shining, sometimes clothed with fine scattered hairs, or with long thick hair. The pronotum is nearly triangular, very much narrowed in front, concave beyond the large elongated, triangular scutellum. The mesosternum projects in a short, blunt, and sometimes clubbed process in front. The legs are strong and rather thick; the front tibix with three teeth on the outer side. They are found on flowers. The larvæ live in hollow trecs and in the nests of the large wood-ant.

* C. (Oxythyrea, Muls.) stictica, Linn. (Plate IX., Fig. 7). Wing-cases and pygidium spotted with white. Sides of the sternum and femora clothed with long thick hair. Abdomen with thin, sessile, white hairs, with a row of longitudinal white spots in the male, extending from the first to the fourth segment, but spotless in the female. It is found on flowers in May, but is very rare and doubtfully indigenous in Britain.

C. (Tropinota, Muls.) hirtella, Linn. (Ylate IX., Fig. 8). This species is clothed in a thick and long pubescence. Each 
wing-casc has five longer, or shorter, channelled, double stripes and a raised elevation. The hairs are somctimes rubbed otf, leaving the upper surface bare and black, spotted with lighter. $I t$ is found in early spring on flowering willows and dandelions, and frequently also attacks garden-flowers. It is common on the Continent, but is not found with us.

* C. aurata, Linn., the Rose Chafer (Plate IX., Fig. 10). ('ypeus somewhat cmarginate in front. It is green, with a folden shine. It is shining coppery beneath. On each side of the suture there is a raised line. It is common in May on flowers and on the exuded sap of trees. The larvæ live in the rotten wood of trees or in ants' nests.

C. affinis, Andersch. (Plate IX., Fig. 11). Elongated, oval. W'ing-cases uniform green, strongly shining. Pronotum flat in the middle, finely punctured on the sides. Process of the mesosternum prominent and rounded in front, much expanded. It is a South European species, which is found in June and July, and feeds on the sap of trees and the spongy galls growing on young oak trees.

C. marmorata, Fabr. (Plate IX., Fig. 12). Clypeus slightly emarginatc in front. It is dark bronze-colour above, with ineuglar white waved markings. The sternum and sides of the abdominal segnicnts have yellow hair upon them. This beetle, which is found in many countrics on the Contincnt, feeds in August on the sap of oaks and willows; it hibernates, and :ppears again the following spring. The larvæ live in hollow troes and in ants' nests.

* C. floricola, Herbst (metallica, Fabr.) (Plate IX., Fig. 13). Clypcus not emarginate in front, or only slightly emarginate. Upper surface varying from green to brownish, with or without wiscel white markings, but not so shining as C. aurata. It is 
always darker bereath, and there is no raised line beside the suture. It appears early in June, and is found on oaks. 'The larve are found also in ants' nests. It is loeal, and is confined to Seotland and the North of England.

C. fastuosa, Fabr. (speciosissima, Scop.) (Plate IX., Fig. 14). Oval, and usually larger than $C$. affinis. Wing-cases uniform green, very shining, with the sutural angle projecting at the extremity. The appendage of the mesosternum is rounded in front. It is found in many parts of the Continent, whore it appears late in the summer, especially frequenting oaks, on the sap of which it feeds. The larvæ live with ants in hollow trees.

Genus Osmoderma, Lepell. and Serv.

Head free; elypeus slightly emarginate in front, with two elevations behind. The hind coxæ are toothed on the inncr side. The pronotum and seutellum are furrowed. The only European species is:

O. emerita, Linn. (Plate IX., Fig. 15). Pitehy-blaek, varying to metallic-reddish. The male has a raised border to the clypeus, which is absent in the female. The beetle, which has a smell of Russia-leather, frequents trees towards the end of June and July. The larvæ live in hollow trees, preferably apple-trees, often gregariously. It inhabits most parts of Europe, but not the British Isles.

\section{Genus Grorimus, Lepell. and Serv.}

Head frce; elypeus square, emarginate in front. Pronotum narrowed in front, with almost rounded angles behind. The scutellum is very obtusely triangular. The elytra are broader than the thorax, and are together nearly as broad as they are long. They are found on flowers and on the trunks of trees.

* G. nobilis, Linn. (Plate IX., Fig. 16). Shining, coppery-red beneath, golden-e:een above, eommonly with a eopper-red shine. 
The pronotum has a fine longitudinal line. The sternum, and also the abdomen in the female, are clothed with shaggy grey hair. The pygidium is convex in the male, and has two stout elevations at the extremity in the female, which are separated by a depression. It is found in May and June on flowers, particularly juniper and meadow-sweet. The larvæ live in rotten wood. It is rare in Britain.

\section{Genus Trichius, Fabr.}

Head free; clypeus somewhat narrowed towards the front, and slightly emarginate. Prothorax covered, both above and below, with shaggy hair. Elytra scarcely longer than broad, yellow, with black markings. The beetles live on flowers, and the larvæ in old posts and decayed trees.

* T. fasciatus, Linn. (Plate IX., Fig. 17). Wing-cases slightly striated, dull velvety, with fine whitish pubescence; either black, with two yellow bands coalescing at the suture, or yellow, with a narrow black external border and suture and three black bands. It is found on flowering shrubs and umbelliferous plants. The larvæ live in old trees and beams. It is very local.

\section{Genus VALGUS, Scriba.}

Head retracted under the prosternum. Wing-cases short, leaving the last two abdominal segments uncovered; the last segment with a long ovipositor in the femalc. There are scales on the head. It is found on flowers.

V. hemipterus, Linn. (Plate IX., Fig. 18). Dull black, with a groove on the pronotum and black and white scales, as on the wing-cases. The male has two black spots at the base of the pygidium. The female has fine grey scales and a long straight ovipositor. It is found at the beginning of May on flowers and on frothy cxcrescences on fruit trees, and is common in many parts of the Continent. The larve live in the 
wood of fences, and in the roots of diseased plum and dainson-trees.

\section{FAMILY XXIV. BUPRESTID卧.}

Antennæ eleven-jointed, filiform or dentated. Mesosternum with an excavation, into which a process of the prosternum fits. The hinder angles of the pronotum are obtuse or rectangular. They are sluggish beetles. The abdomen is composed of five segments, the front ones being more or less amalgamated. The larvæ, which are elongated, witl a large head, live in wood or the stems of plants. The beetles are found on wood, and fly about during the midday lieat.

\section{Genus Chalcophora, Solier.}

Prosternun fiat, with two grooves. Pronotum narrowed in front, widest beneath, with almost straight sides and rectangular hincler angles. The elytra are rather broader than the pronotum, and somewhat flat. The antennæ are obtusely scrrated on the inner side.

C. mariana, Linn. (Plate X., Fig. 1). Shining coppery, almost golden beneath, porvdered in fresh specimens; the pronotum and wing-cases with irregular raised longitudinal striate. It is a native of Southern Europe, where it lives in pine-roods, in sandy places. The larva lives in the old trunks.

\section{Genus Dicerca, Eschsch.}

Distinctly convex. Pronotum unevell. Elytra narrowed behind in an undulating line, the extremity being more or less produced. The extreme end is truncated, usually with two teeth. The abdominal segments are deeply emarginate in the males with a tooth on each side, sharply tridentated in the females. They are found about cut wood in forcsts. 
D. berolinensis, Fabr. (Plate X., Fig. 2). Slining coppery, with a green lustre above. Pronotum punctured, somewhat granular on the sides. Wing-cases thickly punctured, with scattered, raised, dark spots. It is found in lilly districts and in beech-woods on old trunks, in which the larvæ live It is a native of Sonthern Europe.

\section{Genus Lampra, Spin.}

Lateral border of the elytra more or less sliarply dentated towards the extremity. Prosternum suddenly truncated belind, narrowed. The pronotum is equally broad in the middle. Antennæ serrated on the inner side. They are found on the trunks or on the leares of trees.

L. rutilans, Linn. (Plate X., Fig. 3). Golden, or goldengreen. Elytra small, spotted with black. Head and pronotum coarsely punctured, the latter with a golden lateral margin, and black spots on the sides. It is an inhabitant of Southern Europe, and is found on alder and lime-trees, appearing in June.

Genus Buprestis, Linn. (Archylocheira, Eschsch.)

Lateral borders of the elytra not dentated towards the extremity. Pronotum broadest at the base, narrowed in front, witl straight sides. Scutellum small and rounded. Prosternum with a narrow furrow, slightly swollen at the sides, and sharply pointed behind. They are found in the sunsline on the trunks of trees and on felled timber.

B. rustica, Linn. (Plate X., Fig. 4). This is a very variable species, but is usually bluish-green, though it may be bronzy, green, or blue. The under surface is coppery, with white hair. The terminal segment of the abdomen, the front angles of the pronotum, and the front of the head, are liere and 

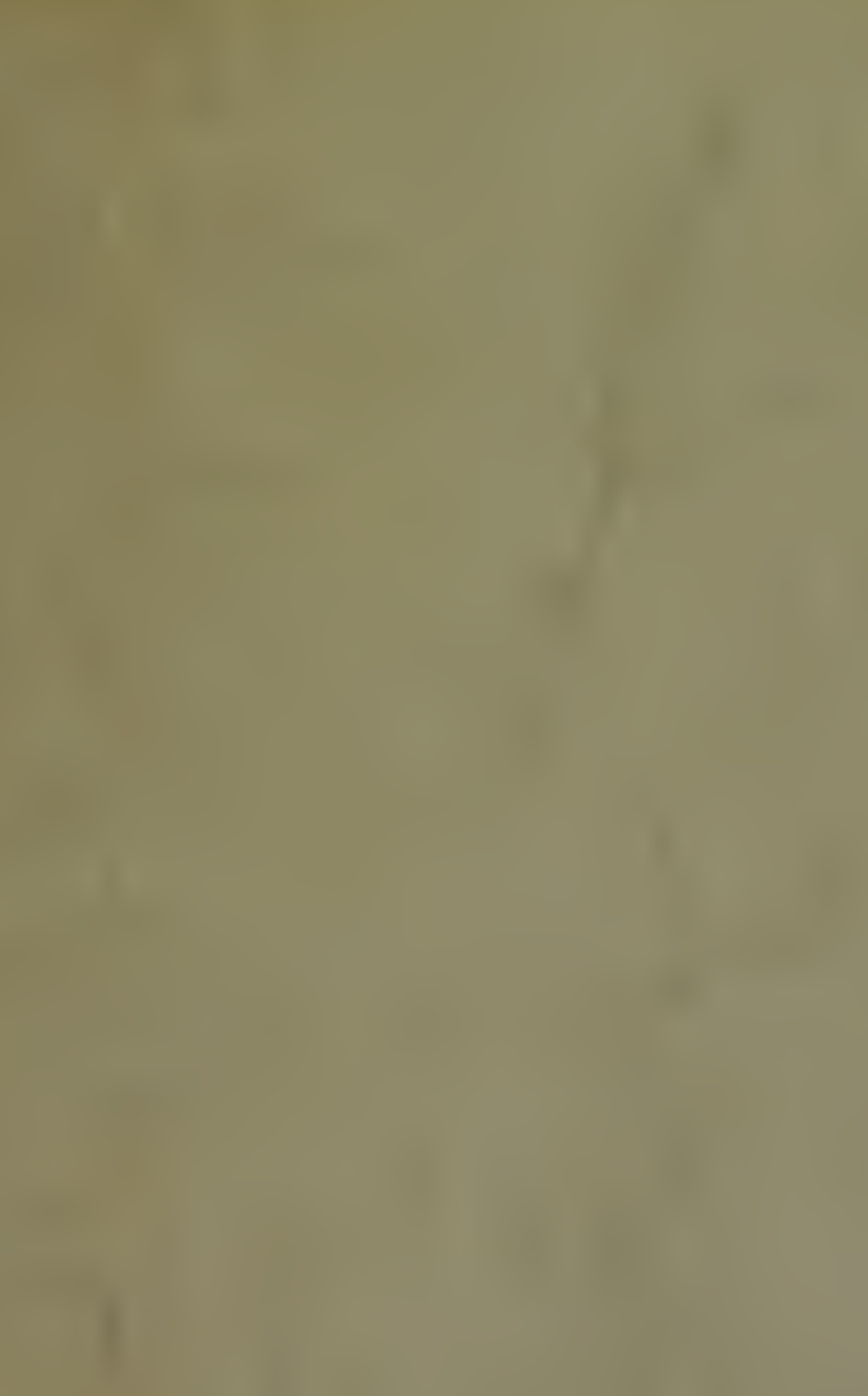

만.

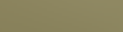

$x^{2}$

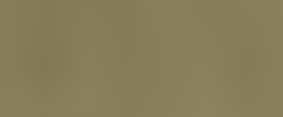

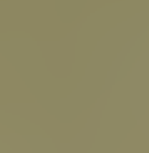



10.

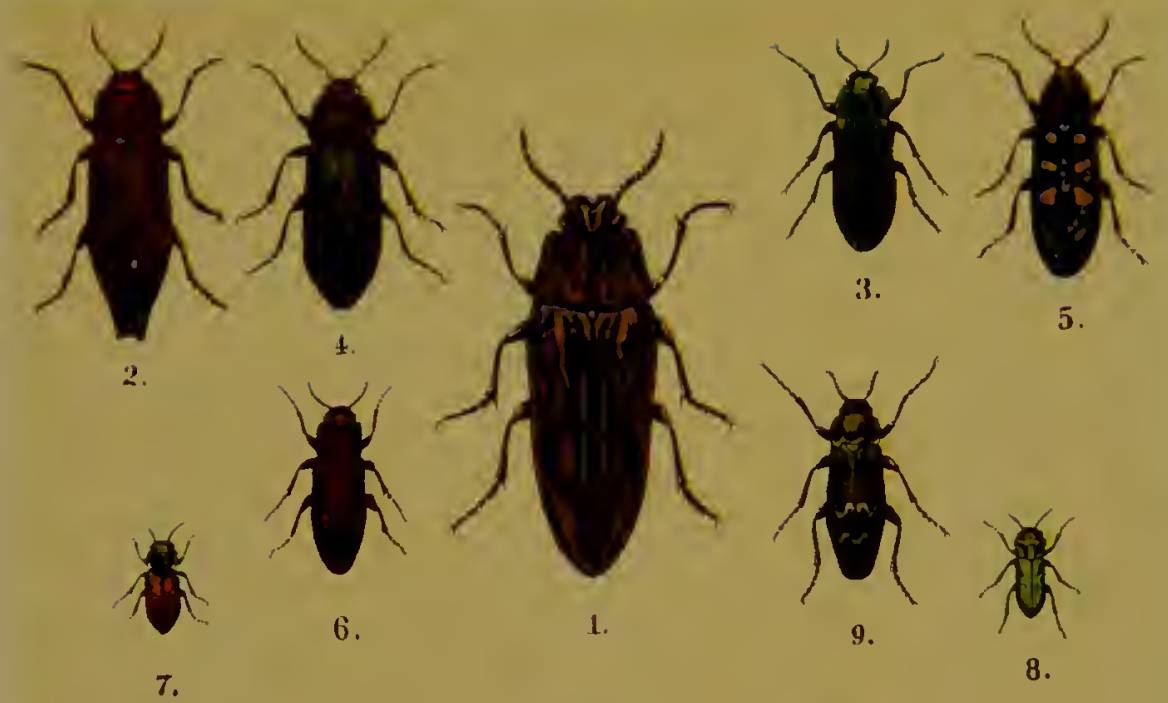

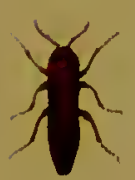

11.
.

12.

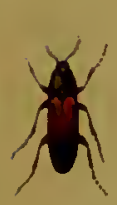

18.

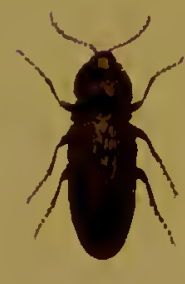

18.

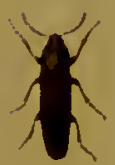

21.
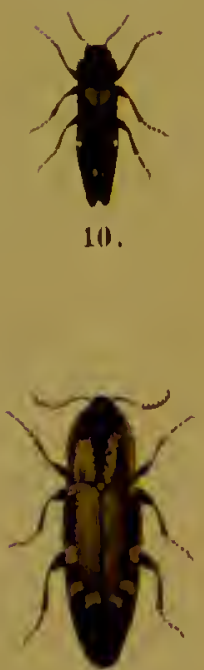

15.

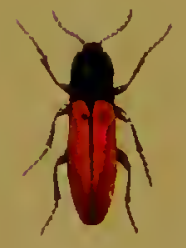

17.

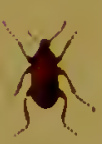

14.

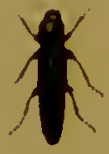

13.

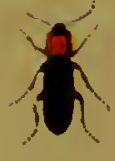

19.
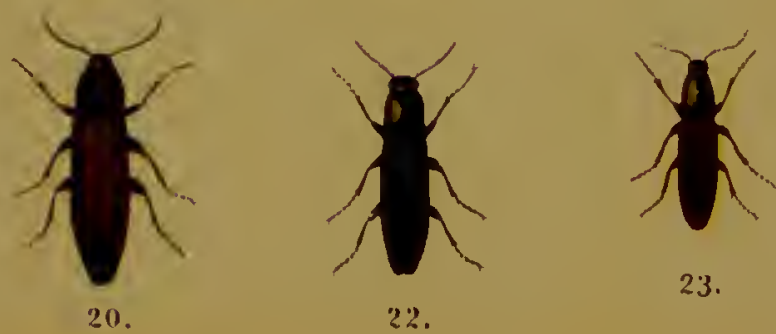

23. 

there spottcd with yellow. It is found in pine-woods, and the larva lives in the wood of the trees. It is a native of Southern and Eastern Europe.

B. flavomaculata, Fabr. (Plate X., Fig. 5). Brown, or dirtygreen, with a metallic shine, with grey hair beneath, dusted above with white. Wing-cases with three or four very variable, frequently coalcscing spots. The borders of the pronotum and several markings on the front of the head are yellow. The sternum and sides of the abdomen arespotted with yellow. It is found in woods in Southern and Eastern Europe, the larva living in pine-trees.

\section{Genus Chrysobothris, Eschsch.}

Pronotum very concave on both sides behind, quadrangular. Elytra oval, narrowed beyond the middle, fairly straight at. the sides, with the posterior border very concave. They frequent timber when the sun is shining.

C. chrysostigma, Fabr. (Plate X., Fig. 6). Metallic purple. Abdomen green in the middle. Elytra dark brown, with two or four shining, coppery depressions, which are situatec. oll the three raised strie, and interrupt them. It occurs on stumps in the middle of June, and the larva lives in oak and pine-trees. It is a native of various European countries, but is not British.

\section{Genus Avthaxia, Eschsch.}

Mostly small, metallic beetles; the pronotum very concave. oll both sides behind. Elytra rather flat, generally parallel, or with slightly granulated sides, more or less pointed or rounded bchind. They are found on flowers and on tree-. trunks. 
A. salicis, Fabr. (Plate X., Fig. 7). Flat, blue or green, with two large dark blue spots on the pronotum. The elytra are bright coppery, with a green or blue triangular spot conmon to both. It is found in May, and frequents flowers. The larva lives in hornbeam. It is a native of Southern Europe.

* A. nitidula, Linn. (Plate X., Fig. 8). Rather elongated; the male green or golden-green; the female with a goldenpurple head and pronotum, and green or blue elytra. The pronotum is twice as broad as long. It is found on flowers, especially on whitethorn and celandine, but is very rare in Britain.

\section{Genus Coribus, Linn.}

Body elongated. Scutellum smooth, broad at the base, oblong, and suddenly and acutely pointed behind. The prosternum is either truncated or has a projecting appendage. The pronotum is broader than long, deeply concave on the sides behind, with a projecting curve in front of the scutellum. It is found on oaks.

C. undatus, Fabr. (Plate X., Fig. 9). Bronzy, granularly punctured. The elytra are darker behind, somewhat hairy, with three narrow, very zigzag bands. It is rarely met with on sprouting oaks, but mostly on old trees which are exposed to the sun. It is fond of hiding itself in the crevices of the bark, and is often difficult to find. The larva feeds on the bark and sap of the oak. It is a native of the southern portions of Central Europe.

\section{Genus AGRILus, Solier.}

Body very elongated. Scutellum with a transverse carina. Prosternum broad and flat, prolonged in front into a projectic: which covers the mouth. Elytra long, expanded in the middie, 
then gradually tapering to the extremity. They appear in June and July, and crawl about on the leaves of the food-plant.

* A.biguttatus, Fabr. (Plate X., Fir. 10). Elytra rounded behind, green or blue, with two sharply-defined white spots. It is found about the end of May. The larva lives in the bark of oak-stumps. It is very local.

* A. sinuatus, Oliv. (Plate X., Fig 11). Olive-green beneath, with a metallic shine; head and pronotum coppery. Elytra dark reddish-purple, with an elongated spot of white hair pointed behind, which is frequently absent. Length, $8-9 \mathrm{~mm}$. It is found on the young shoots of oak-trees and on mayblossoms, but is very rare in Britain.

\section{Genus Trachys, Fabr.}

Pronotum narrowed in front; elytra triangular. Antennæe short, the first two joints thickened, the next four thinner, and the last five suddenly obtuse and serrated and expanded. They are mostly small species, and the larvæ mine the leaves of their food-plants.

* T. minuta, Linn. (Plate X., Fig. 12). Metallic-black, usually with a blue shine, and sparingly hairy. The elytra have four undulating bands. It frequents sallow, and the larvæ mine brown passages in half the leaf. It is local.

\section{FAMILY XXV. EUCNEMID胥.}

These beetles are similar in form to the Elaterida, but have little or no power of juniping. The prosternum has a projection behind, which fits into an excavation of the mesosternum. The antenni have eleven joints, and are serrated or pectinated; rarely with three larger terminal joints. The abdomen is composed of five segments. They live in old rotten wood, and most of them appear to avoid the light and to be nocturnal in habits. 
Genus Tharors, Laporte.

Legs rounded and slender. The first joint of the antennx is long, the second small, the third more than twice as long, and the fourth to the eleventlı provided with long, slender, uniform branches in the males, pectinated in the females. The pronotum is cylindrical, and witlout grooves for the antennx bcneath. Elytra long and cylindrical.

T. melasoides, Laporte (Plate X., Fig. 13). Pitchy-black, with yellowish-grey pubescence. Tarsi reddish-ochreous. Legs brown. Elytra very finely striated, closely and finely punctured. It is found on bushes in June during the noonday heat. The larva lives in beech-trees and in old stored wood. It is common in France and Germany.

Genus Trixagus, Kugelann.

Body elongated oval. Antcnnæ with a large three-jointed club. The head is vertical, and the mouth is covercd by the front margin of the prosternum. The pronotum is broader than long, narrowed in front, convex on both sides at the base, with the hinder angles covcring the shoulders. They frequent damp meadows, and their larvæ live in old oaks.

* T. dermestoides, Linn. (Plate X., Fig. 14). Brown or reddish-brown, closely punctured, and rather thickly clothed with a finc brownish-grcy pubescence. The elytra are striated, with the interspaces very fincly rugose. Length, $2-3 \mathrm{~mm}$. It is local, but generally distributed and common in the London district.

\section{FAMily XXVI. ELATERIDEE (Click Bectles).}

Body rather long, generally narrowed behind. Antennæ with elcven joints, dentated, pectinated, or filiform. The posterior angles of the pronotum are more or less prolonged 
into a pointed spine. The prosternum is lobate in front, with a projection behind, which fits into an excavation of the mesosternum. The abdomen is composed of five segments. Many of these beetles have the power of jumping, and if placed on the back can spring into the air, and in so doing make a clicking noise.

\section{Genus Adelocera, Latr.}

Grooves for the antennæ reaching as far as the front coxæ. Antennæ shorter than the pronotum, serrated on the inner side; the second joint is small, and those following triangular and broader than long. The pronotum is longer than broad, with a sharply ridged lateral border. The elytra are moderately long, and generally pressed down on the back. They are found in rotten wood and under bark.

A. fasciata, Linn. (Plate X., Fig. 15). Black, rather thickly covered with yellow scales, having a golden shine, and sprinkled and spotted with yellowish-white, especially on the greater part of the pronotum, and with a zigzag band beyond the middle of the elytra. It is found under the bark of pines in many parts of Europe, but is not a native of Britain.

\section{Genus Lacon, Germar.}

Grooves for the antennæ not quite extending to the front coxæ, closed behind. Antennæ as long as the pronotuni, the sccond and third joints small and globular, the fourth much broader and twice as long as the third, and the remainder broadly triangular, except the last, which is oval. The pronotum is broader than long, with short, truncated, hinder angles. The elytra are slightly convex, elongated oval.

* L. murinus, Linn. (Plate X., Fig. 16). Black or darik urown, complctely clothed with dense sessile hair of a grey 
or light brown colour, marbled with white. The elytra are finely striated. It is common on flowers, the larvæ in moss.

\section{Genus Elater, Linn. (Ampedus, Germ.)}

The prosternum has an obtuse projection towards the mesosternum, and is without grooves for the antennæ. The antennæ are dentated from the fourth joint, rarely from the third; the second joint is small, the third a little smaller, and the others triangular, the terminal one not being truncated at the end. The pronotum is as long as, or longer than, it is broad, and narrowed in front. The elytra are as wide as the pronotum. The beetles live on flowers and the larve in wood.

* E. sanguineus, Linn. (Plate X., Fig. 17). Black, with scarlet elytra, covered with black hair. The pronotum is almost uniformly punctured. It is found as early as March in pine-stumps, in which the long hard larvæ live. It is very rare, but has been taken in the New Forest.

* E. lythropterus, Germ., is very similar to the last species, but is clothed with reddish-brown hair. It is local.

E. proeustus, Fabr. (Plate X., Fig. 18). Smaller than the preceding. Elytra red, with a black tip. It is found from May to August, and the larva feeds in oak-trees. It is a native of many parts of the Continent of Europe.

Genus Cardiophorus, Eschsch.

Scutellum heart-shaped, appendage of the sternum very short and thick. The antennæ are somewhat acutely serrated, sometimes obtuse. The sccond joint is smaller than those succceding. The pronotum is strongly convex, the sides slightly rounded, and generally only with a sharp bordcr at the basc. The elytra are as broad as, or broader than, the pronutum. They arc found in Howers, and the larve in wood. 
C. thurasicus, Fabr. (Plate X., Fig. 19). Black, with thir whitish hair, and with the pronutum light red. The larva lives in deciduous trees.

C. ruficollis, Linn. Rather smaller than the last. The pronotum is coral-red, with the hind border and the anterior third black. It is common in pine-woods on the Continent, and the larva lives in pine.

\section{Genus Melanotus, Eschsch.}

Scutellum oblong. Antennæ dentated. The second and third joints are much sinaller than the rest, and roundish. The front of the head has a shallow curve anteriorly. The pronotum is gradually narrowed in front. The elytra are long, and widest in front. They are found on flowers. The larvæ live in the wood of old trees, and the beetles are often found in large numbers there too.

* M. castanipes, Payl. (Plate X., Fig. 20). Pitchy-black or pitchy-brown. Antennæ and legs reddish-brown. The pronotum is scarcely rounded at the sides, but narrowed from the middle rowards the front. It is thickly punctured on the sides, and in a more scattered manner in the middle. The elytra are slightly punctate-striate, with finely-punctured interspaces. Jength, $18-20 \mathrm{~mm}$. It is found in mountainous districts in many parts of Europe.

\section{Genus Limonius, Eschsch.}

Antennæ strong, laterally compressed; the second and third joints are small, the fourth to the tenth more or less broadly triangular, the eleventh elongated oval. The head is strongly depressed. The pronotum is somewhat convex, slightly narrowed in front, the hinder angles being obtuse, and occasionally elbowed. Elytria about as broad as the pronotum 
at the base, with straight borders rounded along the last. third of their length. The beetles frequent sumny slopes, where they may be found on the grass, or on shrubs.

L. nigripes, Gyll. (Plate X., Fig. 21). Black, with whitish hair. The pronotum is somewhat closely and heavily punctured, and is nearly as broad as long at the base. The sternal appendage is not furrowed. Length, $8-12 \mathrm{~mm}$. It is common in grassy places in most parts of the Continent.

Genus Athous, Eschsch.

Antennre serrated, or with almost cylindrical joints. Head large, moderately depressed, sharply-ridged in frorit. Pronotum slightly rounded at the sides, the hinder angles generally sliort and obtuse. The elytra are fairly long, scarcely broader than the pronotum. The torsi are rather thick, with the joints generally expanded and sponge-like, or slightly lobed beneatl. The numerous species, which are mostly brown, live on flowers, and their larva under the bark of trees.

* A. niger, Linn. (Plate X., Fig. 22). Shining black, with fine, grey pubescence. The antenur are longer thau the head and pronotum, and the second joint is mucl smaller than the third. The pronotum is finely punctured, and is expanded in the middle. The elytra are finely punctured, and slightly striated; they are rather broader than the pronotum. It is common in bushes.

* A. hcomorrhoidalis, Fabr. (Plate X., Fig. 23). This is a somewhat elongated, uniformly broad, hairy, pitchy-brown, or black, beetle, with light brown wing-cases. The abdomen is tipped with reddish-brown, and the borders of the wing-cases lave the same colour. The antemne are slender, with the third joint almost twice as long as the second, and conicai 
in shape. It is common on hazel, and on leath growing under pines.

\section{Genus Conymbires, Latr.}

Wing-cases generally slightly oval, as broad as the pronotum at the base, but more than twice as long. The prosternum is without distinct grooves for the antennæ. The trochanters are simple and slender. The antennæ vary, and have branches on the inner side in the males of some species. They are found on grass, bushes, and flowers, as well as under stones.

C. hamatodes, Fabr. (Plate XI., Fig. 2). Black, with bloodred wing-cases and a red head and pronotum, clothed with a velvety down. The nnale has branched antennæ. It appears in early spring on the shoots of willows and mountain-ash. It is found in most parts of the Continent.

* C. castaneus, Linn. Elytra orange, tipped with black, distinctly punctate-striate. Head and pronotum thickly covered with yellow, felt-like hair. Length, $9-10 \mathrm{~mm}$. It is very rare.

* C. cupreus, Fabr. (Plate XI., Fig. 3). Elytra yellow in front, with the tip metallic-green or bronzy, frequently entirely bronzed, like the pronotum. Length, $15 \mathrm{~mm}$.

* C. pectinicornis, Linn. (Plate XI., Fig. 1). Shining brassy, with more or less green. The antennæ are black, with the branches in the male more than twice as long as the separate joints. The elytra are finely punctate-striate, flat in the male, distinctly convex in the female. Length, 14-18 mm.

* C. tessellatus, Linn. Metallic-brown, clothed with patches of thick silky yellow pubescence, which gives the upper surface a rather variegated appearance. Length, $8-9 \mathrm{~mm}$. It is found in grassy places.

* C. aneus, Linu. (Plate XI., Fig. 4). Rather broad, smooth, and of a shining metallic-green, blue, coppery, or black, with dark 
metallic or red legs. The pronotum is almost quadrangular, with a ceutral furrow which disappears in front. 'The wing-cases are finely punctate-striate, with finely punctured interstices. Length, 10-14 $\mathrm{mm}$. It is found principally in hilly districts.

Genus Ludius, Latr.

Trochanters rather broad, toothed on the hinder border. Antennix acutely dentated from the fourth joint, with the second and third joints very small and rounded, and the eleventh with a distinctly-defined awl-shaped extremity, but otherwise closely resembling the last genus. The only British species is :

* L. ferrugineus, Linn. (Plate X., Fig. 5). This is one of the largest of the click-beetles. It is black, with the pronotum as far as the posterior margin, as well as the elytra, dull orangecolour. The pronotum is, however, frequently entirely black. It frequents flowers in June and July. The larvæ feed in the. dead wood of various trees, especially willows. It is very rare in Britain.

Genus Agriotes, Eschsch.

In these the sides of the pronotum are obtuse, the margin being deflexed in front. There are no grooves for the antennæ.. The antenuæ are somewhat dentated, and only slightly compressed laterally. The second, third, and fourth joints are all of different lengths. The wing-cases are scarcely broader, but. more than twice as long as the pronotum. The tarsal joints. and claws are simple. They are found on flowers. The larvalive in the ground on the roots of low plants, and are known. as the inuch-dreaded "wire-worms."

* A. lineatus, limn. (segetis, Bjerliand), (Plate XI., Fig. 7). The second joint of the antenux is longer than the third. Theelytra are brown, with the second and third intervals between. 




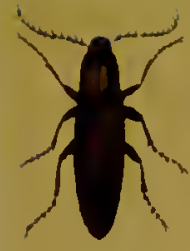

1.

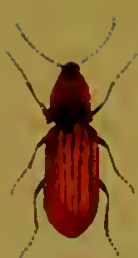

2.

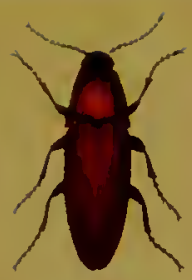

5.

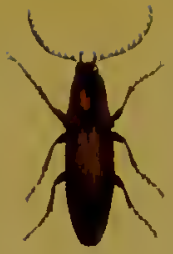

3.

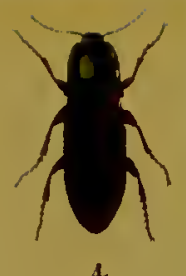

4.

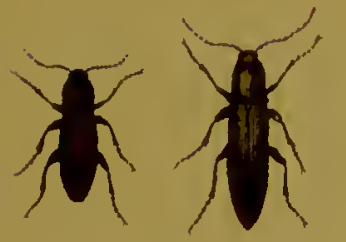

7.

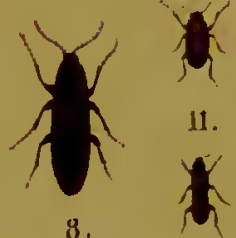

13.

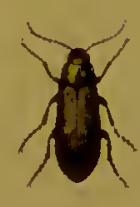

10.

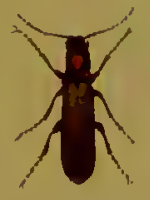

9.

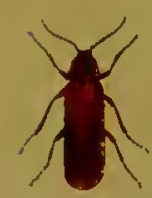

12.

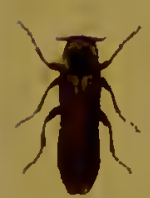

14.

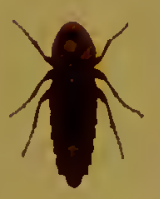

15.

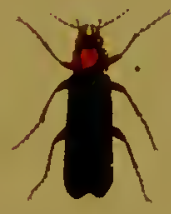

17.

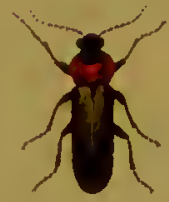

18.

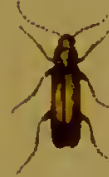

19.

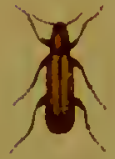

20.

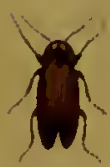

16.
*

21.

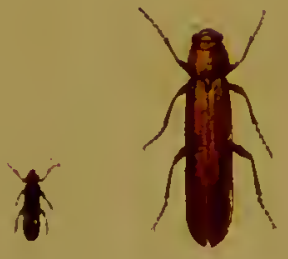

22.

32.

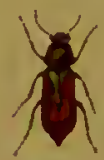

23. is

$2 t$. th

25.

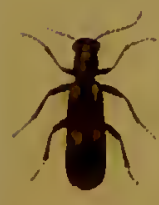

27.

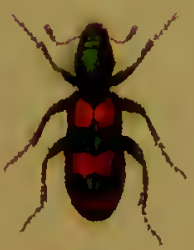

29.

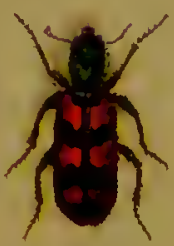

30.

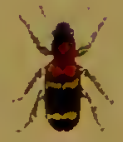

28.
16

31. 

the punctate striæ dark brown or black. Length, 6-7 mm. It is a common insect. The larvæ are often very destructive to the roots of grass and corn.

A. pilosus, Fabr. (Plate XI., Fig. 6). In this species the pronotum is longer than it is broad, brown or brownish-black, clothed with thick sessile hair. The second joint of the antennæ is as long as the third, but distinctly shorter than the fourth. Length, 14-15 mm. It is found on flowers and bushes on the Continent, especially in mountainous localities.

\section{Genus Sericosonus, Redt.}

Wing-cases as broad as the pronotum, and twice as long. The second and third joints of the antennæ are equal, usually smaller than the others, and knob-like; occasionally they are very short. The remaining joints are triangular and distinctly dentated on the inner side. The prosternum has the front margin somewhat rounded and slightly retracted, with a pointed projection towards the mesosternum. They are found on flowers.

* S. brunneus, Linn. (Plate XI., Fig. 8). Elongated, reddishochreous, densely punctured. Head and lower surface black. Pronotum red, with a broad black median line, and the lateral borders black behind. Wing-cases finely striated, with the interspaces closely and evenly punctured. Length, 9-10 mm. It is found in sandy places under stones.

\section{Genus Campylus, Fisch.}

Wing-cases almost of uniform breadth. Antennæ notably longer than the head and pronotum; the second joint very small, and from the third to the tenth nore or less dentated, often with a branching extremity on the inner side in the males. The clypeus is broad and excavated. The prostermum has short projections behind between the front coxæ, and is 
truncated in front, leaving the inouth parts exposed, and without grooves for the antennæ. Thcy are found on bushes, and the larvæ under the bark of trees.

* C. linearis, Linn. (Plate XI., Fig. 9). The elytra arc yellow in the male, frequently with a black suture, rarely quite black. In the female they are black, margined with yellow, rarely entircly yellow. The front part of the head and the pronotum are red, the latter frequently with a black spot in the middle. Length, $10 \mathrm{~mm}$. It is found under the bark of oak and alder, in which the larva also lives. It is not uncommou.

\section{FAMILY XXVII. DASCILLID无.}

Elytra covering the abdomen. Antennæe eleven-jointed, filiform, or dentatcd. Prosternum without a projection towards the mesosternum. Tarsi five-jointed, with the last joint but one bilobate or simple, in which case the antcnnæ are situated nearer the front of the head. They are found on flowers. The larvæ live on the roots of plants.

\section{Genus Dascillus, Latr. (Atopa, Payk).}

Body elongated and cylindrical. The first three tarsal joints are lobate. Antennæ filiform, with the second joint very short. Head bent forward, much narrower than the pronotum, which is twice as broad as long, somcwhat narrowed in front, and with two slight concavities bchind.

* D. cervinus, Linn. (cinereus, Fabr, ð), (Plate XI., Fig. 10). This is the only British species. It is black, clothed with very thick and fine grey pubescence, and has cither only the claws and apex of the abdomen yellowish-brown, or the antenne, legs, and elytra also. It is most frequently met with in chalky listricts, where it lives on flowers and flowering slırubs. 
Genus Helodes, Latr. (Cyphon, Payk).

Elongated, or rounded oval. The antennæ are filiform, with the second and third joints smaller than the others. The body is oval. The pronotum is much broader than long. The legs are simple. The fourth joint of the tarsi is bilobate. The elytra cover the abdomen. The beetles are found on flowers.

* H. testaceus, Linn. (lividus, Fabr.), (Plate XI., Fig. 11). Pale yellowish-brown, finely and closely punctured, and with fine pubescence. The antennæe are dark brown, with the exception of the first three joints; and the margins of the pronotum and elytra are frequently of the same colour. Length, $4 \frac{1}{2} \mathrm{~mm}$. It is common in swampy meadows.

\section{FAMILY XXVIII. MALACODERMID压.}

Body soft. Antennæ eleven-jointed, setiform or filiform, serrated or pectinated. Some of the females are without elytra. Most of the species live on flowers.

\section{Genus Eros, Newman.}

Elytra with prominent raised longitudinal striæ; flattened. The head is nearly hidden under the raised front border of the pronotum. The antennæ are flattened, and almost always have the third joint larger than the second. They are found on tree-trunks and flowers.

* E. aurora, Fabr. (Plate XI., Fig. 12). Pronotum and elytra red, the former generally margined with darker, with four broad shallow grooves, and a small diamond-shaped depression in the middle. It is dark brown beneath. This beetle frequents flowers, and the larva lives in old oak-trees. It is very local.

E. (Homalisus) suturalis, Fabr. (Plate XI., Fig. 13). Black, finely pubescent, with red wing-cises, having a blackish stripe 
over the suture, rarely quite black. It is pitchy-brown on the under surface. The antennæ and legs are brown. It is found in shady, grassy places, and is a native of the southern parts of Central Europe.

\section{Genus Lampyris, Linn.}

Head completely covered by the pronotum, which is rounded in front. Antennæ filiform and compressed. On each of the last two abdominal segments there is a small light-producing spot, which appears yellow when the beetlc is dead. The males fly at night, whilst the worm-like females are to be found in the grass in damp places. The larvæ live in dccaying trees.

L. splendidula, Fabr. (Plate XI., Fig. 16j. Flat and elongated, brown, with three translucent spots on the front of the pronotum. The elytra are not much more than twice as long as broad. The fcmale is pale yellow, with two yellow scales in place of wings. It is found in most parts of Central and Southern Europe, but is not British.

* L. noctiluca, Linn., the Glow-worm (Plate XI., Fig. 14ð, Fig. $15 \%$ ). This species is about 3 or $4 \mathrm{~mm}$. longer than the last. It has greyish-brown elytra, which are three times as long as the breadth of both together. The pronotum is greyish-yellow, with a darker border. The female is brown, without any trace of wings.

Genus Telephorus, Schaeffer (Cantharis, Linn).

Body soft and elongatcd. Head prominent. Scutellum small, with a rounded point. The elytra are somewhat broader than the pronotum, and cover the abdomen completely. The antennæ have eleven joints, and are filiform or setiform; they are inserted on the front of the head before the eyes. The beetles are found on flowcrs. 
- T. abdominalis, Fabr. Male black, with orange mouth and abdomen, and blue elytra. Female black, with the basal joint of the antennæe, the front part of the head, the scutellum, prosternum, and front femora, orange. Length, 13-14 mm.

T. violacens, Payk. (Plate XI., Fig. 17). This species is similar to the last, but lias the pronotum also orange. It is found in many places on the Continent, on pines and fir-trees.

* T. obscurus, Linn. Black, with fine grey hairs, which are closer beneath than above. The lateral borders of the pronotum are yellow, and the first two joints of the antennæ, as well as the margins of the abdomen, are for the most part yellow. It is rare and local in England.

* T. fuscus, Linn. (Plate XI., Fig. 18). Black, with fine grey pubescence. The base of the antennæ, the front part of the head, and the pronotum are orange, the last with a black spot on the front border. It is found on fruit trees and shrubs.

T. lineatus, Kiesenw. (Plate XI., Fig. 19). The elytra are pale yellow. The eyes, a double spot on the pronotum, the posterior border of the vertex, the sternum, and middle of the abdominal segments, are black. The tips of the antennie are brownish. This species inhabits the Pyrenees.

* T. (Rhagonycha) fulvus, Scop. (Plate. XI., Fig. 20). Wingcases entirely yellow, tipped with black. Legs and antennæ, with the exception of the base of the latter, black. It is very common on flowers.

\section{Genus Malthinds, Latr.}

Wing-cases generally shorter than the body. Head large and somewhat flat, with a broad front; much narrowed behind the eyes towards the base. The antennæ are filiform, and placed at some distance from the inner border of the eyus. 
They are found gregariously on flowers and bushes standing in grassy places.

M. biguttatus, Payk. (Plate XI., Fig. 21). This species is black, finely hairy. The elytra are punctate-striate and tipped with sulphur-yellow. The front part of the head, the base of the antennie, and the femora, are yellow. Length, 6-7 $\mathrm{mm}$. It is found in various parts of the Continent, especially in mountainous districts.

* M. (Malthodes) marginatus, Latr. (Plate XI., Fig. 22). Elytra greyish-brown, tipped with sulphur-yellow. The mouth, legs and tarsi, the edges of the pronotum, and some markings on the abdomen, are yellow. The pronotum is nearly quadrangular. It is common in and near woods.

* M. (Malthodes) sanguinolentus, Fall. The pronotum is orange, with a darker spot in the middle. The elytra are brown, tipped with sulphur-yellow; and the legs and the edges of the abdominal segments are yellow. Length, $4 \mathrm{~mm}$. It is common in damp roods.

\section{Genus Malachius, Fabr.}

Antennæ inserted between the eyes, eleven-jointed. Elytra scarcely broader than the pronotum, twice as long as broad, and expanded towards the extremity. The beetles live on flowers.

* M. ceneus, Linn. (Plate XI., Fig. 23). This species is coppery-green with dull-red elytra, very finely granulated, with a green spot. The second joint of the antennæ is produced in a point internally at the apex in the male, and there is a long curved hook on the third. The larva lives in thatch.

* M. bipustulatus, Fabr. (Plate XI., Fig. 24). Shining green, with the mouth yellow, and the front angles of the pronotum and tips of the wing-cases red. The basal joints of the 
antennæe with larger or smaller processes on the inner side in the male. The larva lives in the old wood of willows. The beetle is very common on flowers.

* Mr. marginellus, Fabr. This species is also shining green, with a yellow mouth. The tips of the wing-cases are orange. The pronotum is broadly bordered with red. The joints of the antenne, from the third to the seventh, are excavated on the inner side in the male, and the seventh is produced at the apex into a blunt tooth.

\section{Genus Anthocomus, Erichs.}

Abdominal segments interrupted in the middle, and membranous. Antennæ eleven-jointed, filiform, rarely slightly serrated or dentated.

* A. fasciatus, Linn. Elytra black, with a broad red mark on each before the middle, and a smaller band of the same colour at the extremity. The extremities of the elytra are reflexed in the male, with a small appendage.

\section{Genus Dasytes, Payk.}

Pronotum scarcely longer than broad, body clothed with erect hair. The claws are simple in both sexes. The antennæ have eleven joints, and are situated on the sides of the head in front of the eyes; they are filiform and generally dentated. The beetles live on flowering trees and bushes.

D. cornuleus, Fabr. (Plate XI., Fig. 25). Wing-cases blue, granulated. Antennæ and tarsi black. Pronotuin deeply and sparsely punctured. The beetle is found in old branches of oak and beech trees, where the larvæ perhaps prey on wood-boring beetles. It is collmon in many parts of the Continent. 


\section{FAMILY XXIX. CLERID瓜.}

Body generally cylindrical. Antennæ either gradually thickened, or with three enlarged terminal joints; eyes emarginate. The front coxæ are prominent, and the posterior ones are oblique. The tarsi are four- or five-jointed, with spongy soles, by means of which the beetles can hold very tightly. They live on flowers and prey on other insects, and some of them enter bee-hives and kill the bees.

\section{Genus Trluos, Oliv.}

Prosternum fused with its lateral appendages. The tarsi have five joints, and the first joint is visible from above. The head is oval. The antennæ are serrated from the third joint to the end, and the second joint is small. The elytra are of uniform width, or slightly expanded beyond the middle. The beetle lives on flowers or freshly-hewn timber.

* T. elongatus, Linn. (Plate XI., Fig. 26). This species is black and finely pubescent. The elytra are bluish-black, punctate-striate. The pronotum is red in the female and black in the male, which is the smaller sex. It is found on old oaks, beeches, willows, \&c., but is not common.

\section{Genus Opilus, Latr.}

This genus closely resembles the last, but the first joint of the tarsi is hidden by the second, and is more or less abbreviated. The eyes are large and prominent. The beetles are nocturnal in habits, and live in houses and in trees, where the larvæ prey on other insects.

* O. mollis, Latr. (Plate XI., Fig. 27). This species is dark brown. The antennx, the legs (with the exception of the middle of the femora), the tips of the elytra, and the square spots on them, are pale yellow. The abdomen is 
orange-eoloured. It is found under the bark of dead oaks, lime trees, and in rafters. The larva occurs in houses among rubbish. It is rather searee and loeal.

\section{Genus Clerus, Fabr.}

Pronotum almost heart-shaped, strongly constrieted behind, and with a transverse impression before the extremity. The antennie are gradually thiekened towards the extremity. The last three joints are as broad or brcader than they are long, and the last has an oval extremity. They are found on the stems of trees.

* C. formicarius, Linn. (Plate XI., Fig. 28). Pronotum and elytra red at the shoulder angles, the latter with two white bands. It is found on fenees and in tree-trunks. The larva preys on wood-boring beetles.

Genus Trichoves, Fabr.

Body elongated. Pronotum attenuated behind, and transversely compressed in front of the extremity, so that the front margin appears to be somewhat raised. The antennæ have a three-jointed terminal elub, the last joint being very large and obliquely truneated. The tarsi are four-jointed. The males usually have rather stout hind femora. They live in flowers, where they lie in wait for other insects. The larræe, which are red, live in the nests of bees.

* T. apiarius, Linn. (Plate XI., Fig. 29). This speeies is dark blue, with thiek pubescenee. The elytra are red, with two broad bands, and the tip blue-black. It is found in the nests of honey bees and mason bees. It has been met with in Britain, but has been probably introduced.

* T. alvearius, Fabr. (Plate XI., Fig. 30), is very similar to the last speeies, but is not so hairy, and the end of the clytra is 
red. It is found in the nests of carpenter bees and woodcutting bees. This species has probably also been introduced.

\section{Genus Conynetes, Herbst.}

Body elongated. Pronotum distinctly longer than broad, rather expanded in the middle in front. The clytra have scattered punctures. The tarsi have four joints, the first being hidden in the second. The claws are expanded in a tooth-like manner at the base. Thesc beetles live on flowers or on dry carrion.

* C. coruleus, De Geer (Plate XI., Fig. 31). Blue or greenish-blue, pubescent, darker beneath. Antcnnæ black; legs dark blue; elytra with scattered punctures. It is occasionally found on rotting oaks.

\section{FAMILY XXX. LYMEXYLONID庄.}

Body elongated, cylindrical. Antennæ filiform or slightly fusiform, serrated or pectinated. The prosternum has no. projection towards the mesosternum. The elytra are not convex at the extremity, but diverging. Both the beetles. and their larvæ are found in felled timber.

\section{Genus HyLECœTUS, Latr.}

Pronotum broader than long. Antennæe eleven-jointed, serrated or pectinated, with the second joint small. The last joint of the palpi has a tuft of long, narrow lamellæ in the males, but is thickened and truncated at the extremity in the females.

* $\boldsymbol{H}$. dermestoides, Fabr. (Plate XI., Fig. 32). Antennæ serrated. We have figured the female. The male is much smaller than the female, and either entirely black, with only the legs reddish-brown or yellow, or else with the antennit and elytra yellowish-brown, with the exception of the extremity 
of the latter, which is black. The larva lives in beech, fir, and oak trees. It is very local.

Genus Lymexylon, Fabr.

Pronotum longer than broad, attenuated in front. Abdomen with five segments. The antennæ have eleven joints, and are filiform, slightly expanded in the middle. The only British species is:

* L. navale, Linn. The male is $5-9 \mathrm{~mm}$. in length, with the elytra at the base as far as the middle of the suture, the abdomen and legs, yellow. The female averages 8-14 mm., and is ochre-yellow, with the head, the margins, and tips of the elytra, blackish. The larva lives in the wood of oaks.

\section{FAMILY XXXI. PTINID五.}

Elytra covering the abdomen. Antennæ with from nine to eleven joints, filiform, serrated, pectinated, or with three enlarged terminal joints. The prosternum has no projection towards the mesosternum. The tarsi are five-jointed, the first two joints being about equal. The claws are simple. The beetles live in wood and dry vegetable and animal substances.

\section{Genus Hedobia, Ziegl.}

Elytra cylindrical, more than half again as long as broad. The antenuæ have eleven joints, and are longer than the body; they are filiform. The first joint is the stoutest, the second is small, and the remainder are about equal in length. They live on flowering shrubs and the larvæ in old wood.

* H. imperialis, Linn. (Plate XII., Fig. 1). This is a fuscous species clothed with whitish down. The elytra have a waved white patch, and a white spot near the extremity. The antennæ and legs are dull red. It lives in the old stumps of walnut, hazel, beech, and damson trees, as well as in old white-thorn bushes. It is widely distributed. 
Genus Prinus, Linn.

Body short, oval. Antennæ with eleven joints, long and filiform, situated between the eyes. The legs are slender at the base, but club-shaped near the knee. The tarsi are five-jointed, with the third and fourth joints simple. The beetles live in dry wood and vegetable substances, some of then in louses, and are very destructive to natural history specimens.

* P. fur, Linn. (Plate XII., Fig. 2). Male nearly cylindrical, red, reddish-brown, or pitchy-brown, and pubescent. The head is eovered with white hair. The female is much larger than the male, and elongated oval. The pronotum is eovered with large yellow tufts of hair, coalescing behind. It is common and destructive in houses, where it frequents the larder; and in drug-stores, on the dried portions of plants, and particularly sceds. It also frequently attacks collections of insects and plants.

* P. (Niptus) hololeucus, Falderm. (Plate XII., Fig. 3). Globular, completely elothed with thiek, golden-yellow pubescence. This little beetle was originally a native of Asia Minor, but has been gradually introduced with merchandise, and is now sometimes destructive to wool, drugs, and other dry materials.

\section{Genus Gibbium, Scop.}

Body small, humped, and wingless. Elytra grown together at the suture, and raised into a bladder-like translueent ball. The antelnæe are eleven-jointed, filiform, and nearly as long as the body. The third and fourth joints of the tarsi are simple. It is found on animal products.

* G. scotias, Fabr. (Plate XII., Fig. 4). Chestnut-brown, glassy, shining, and translucent. Pronotum very short. Antennæ and legs clothed with shining yellow pubescencc. Length, $3 \mathrm{~mm}$. It is occasionally found in woollen stuffs, and espeeially in sheep's wool, but is rare. 




\section{2.}

$+\quad *$

1.

2 .

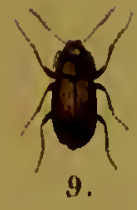

10.

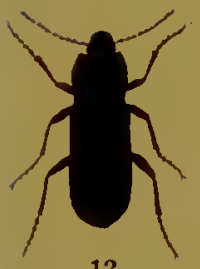

12.
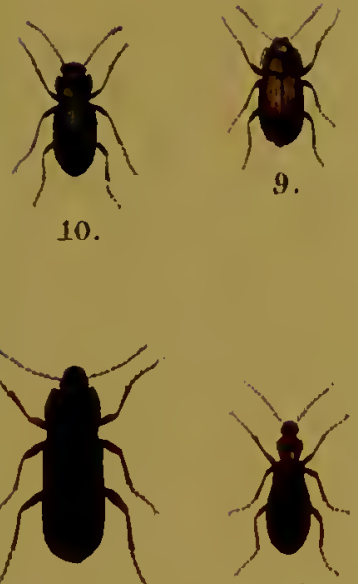

17.
3.

7.

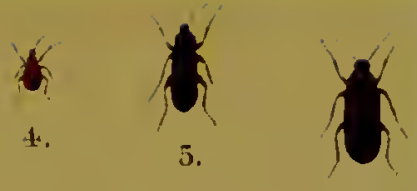

6.

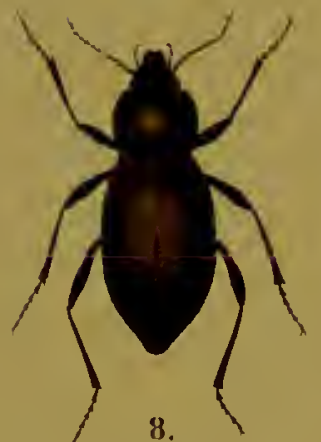

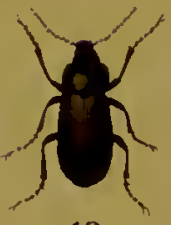

13.

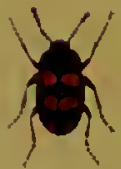

11.

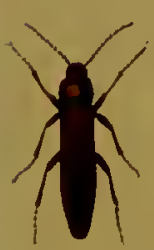

19.

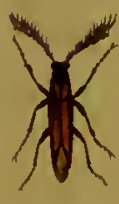

25.

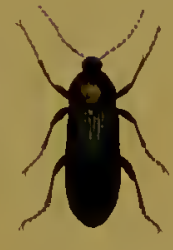

20 .

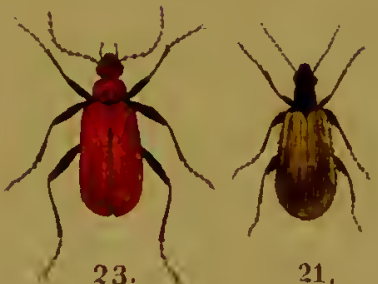

23.

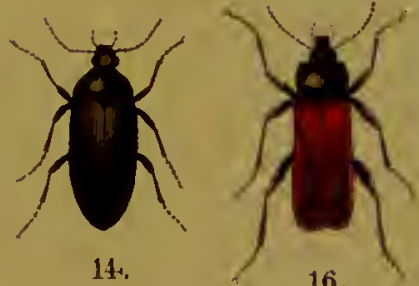

16.

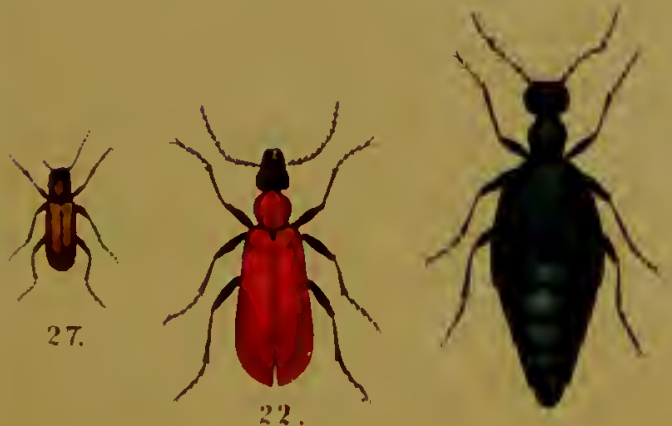

26.

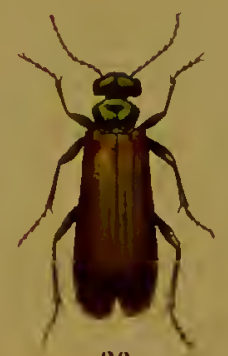

29.

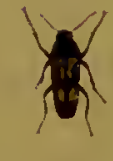

24. 



\section{Genus Anobium, Fabr.}

Body cylindrical. Antennæe eleven-jointed, with the first joint large and stout, and the rest small and roundish. The last three joints are long and flattened. They are placed in front of the eyes. The beetles are found on flowers and in wood, especially. in furniture and fittings, of which the larvæ are especially fond.

* A. pertinax, Linn., the Death Watch (Plate XII., Fig. 5). Elytra punctate-striate, dark brown. The pronotum has three pits in the middle, and two behind at the hinder angles, as well as a yellow pubescent spot. It is common in old willows and in household fittings, and if touched feigns death. The males. knock vigorously against the wood with their heads, producing. the so-called death-tick, and the females answer them.

* A. striatum, Oliv., is a similar species, but smaller; and another of the genus (* A. paniceum, Fabr.) lives in stale bread.

*A. (Xestobium) tesselatum, Fabr. (Plate XII., Fig. 6). Elytra. irregularly punctured, dark brown, with yellowish pubescent. spots. The pronotum is convex, without distinct pits. Length, $5-6 \mathrm{~mm}$. It is common in the wood of trees, especially in oaks.

Genus Apate, Fabr. (Bostrychus, Geoff).

Pody cylindrical. Head rather small, nearly oval, sunk into. the pronotum almost as far as the eyes. Clypeus slightly concave in front. Pronotum roughly convex. Antenne with ten joints, the first and second being a littlc longer than the five following. These beetles swarm in the evening in woods. in May and June. The larvæ live in wood.

* A. capucina, Linn. (Plate XII., Fig. 7). Black, with red! wing-cases and abdomen. The pronotum is not concave in front. The wing-cases arc deeply and irregularly punctured. It. lives in decayed oak and linc trces, and is very rare in Britain. 


\section{Section II. HETEROMERA.}

(Beetles which have five joints to the first and second pairs of tarsi, and four to the hind pair.)

\section{FAMILY XXXII. TENEBRIONID正.}

These are, for the most part, black in colour. The antennx are inserted under the expanded lateral border of the head, which covers the first joint to a greater or less extent. The abdomen is globular or oval.

\section{Genus BLAPS, Fabr.}

These are wingless beetles, with short antennæ, the last joints of which are almost spherical. The elytra are rather broader than the pronotum, and nearly twice as long as broad. They live in dark places.

* B. mortisaga, Fabr., the Cellar Beetle (Plate XII., Fig. 8). This species has a yellow tuft of hair in the middle of the hind border of the first abdominal segment in the male. Both the beetle and its hard, elongated larva are found under rotten boards, and in cellars. It is very rare in Britain, though onc or two closely allied species are common.

\section{Genus Opatrum, Fabr.}

Body rather flat, broad, and oval. The front coxæ are only slightly further from one another than the niddle pair. The eyes are at the lateral margins of the head, and divided into two. They are found under stones in sandy places.

* O. sabulosum, Linn. (Plate XII., Fig. 9). This insect is black, ashy-grey above, and slightly convex. The front tibize 
are expanded into a triangular tootl at the extremity. It is found on sandy roads in spring, and is common locally.

\section{Genus Bolitophagus, Illig.}

Antennæ gradually thickened towards the extremity. Mouth-parts quite covered by the rough clypeus. The wingcases are broad and shortly cylindrical. They live in fungi growing on trees.

* B. reticulatus, Linn. (Plate XII., Fig. 10). This species is black or brown, with the pronotum expanded in front of the middle, and much narrowed behind. It is found in fungi, and is almost confined to the Tay district in Britain.

\section{Genus Diaperis, Geoffr.}

Body short, oval, and very convex, almost hemispherical. The process of the prosternum is narrow. The only species is :

* D. boleti, Linn. (Plate XII., Fig. 11). Elytra with very fine scattered punctures, and yellow bands. It lives in fungi growing on oak and beech trees, and under the damp bark.

\section{Genus Tenebrio, Linn.}

Body elongated. Antennæ inoniliform, slightly thickened towards the extrenity, with the third joint the longest. The pronotum is broadest in the middle. The beetles live in rotten wood.

* T'. molitor, Linn., the Meal-worm Beetle (Plate XII., Fig. 12). Pitchy-black or brown, finely punctured. The under surface and legs are reddish-brown. It is found in old flour and bread troughs, and in the rotten wood of oak and pinc trecs. The larva is known as the "meal worm."

\section{Ger:us Helops, Fabr.}

Eyes kidney-shaped. Pronotum closely fitting to the wingcases. Antemne filiform, and longer than the head and 
pronotum together, witl the second joint very short and the third longest. It lives under the bark of trees.

* H. striatus, Fourc. (Plate XII., Fig. 13). This species is shining black, pitchy-brown beneatl, with reddish-brown antennæe and legs. It lives in winter under moss, and in summer under the bark of pine trees. It is common in the South of England.

Genus Cistela, Geoffr.

Elytra long, oval, clylindrical, and convex. Antennæ serrated, either filiform or setiform, situated at the front margin of the eyes, with the second joint short, and rarely the third also. The beetles live on flowers.

* C. atra, Fabr. (Plate XII., Fig. 14). Shining black, with very fine pubescence, and a red mouth, antennæ, and legs. It lives in the decaying wood of old oaks, elders, and willows, and is found on the trunks at night. It is very local.

* C. sulphurea, Linn. (Plate XII., Fig. 15). This species is yellow with black eyes, and the tips of the antennæ, the palpi, and legs, blackish. It is found on the coast on Peucedanum and dogwort (Cynanchum).

\section{Genus Omophlus, Solier.}

Head fitting into the pronotum, and more or less retractile as far as the eyes. The pronotum is equally attenuated in front and behind, and has the front margin truncated. The beetles live on flowers.

O. betulo, Herbst (lepturoides, Fabr.) (Plate XII., Fig. 16). Wing-cases reddish-ochreous or rusty-yellow, with the pronotum narrow and black, and the antennie and legs also black. Length, 12-16 mn. It is found in wood-yards and on fodder in most parts of Central and Southern Europe. 


\section{FAMILY XXXIII. PYTHID尼.}

Head produced, with round, prominent eyes. Body flat. Antennæ almost filiform, and very slightly thickened towards the tips, with the last joints broader than long. They are found under the bark of trees.

\section{Genus Pyтho, Latr.}

The only species is:

* P. depressus, Linn. (Plate XII., Fig. 17). Black, with the mouth, antennæ, tibiæ, and tarsi, rusty-red. The abdomen is more or less completely brown, and the elytra are frequently blue-black or steel-blue. It lives under the rotten bark of trees.

\section{FAMILY XXXIV. MELANDRYID正.}

Head triangular, slightly produced, or retracted into the pronotum. The pronotum is narrowed in front, but usually nearly as broad as the wing-cases behind. They are found under the dead wood of trees, or in fungi.

\section{Genus Orchesia, Latr.}

Body narrowed behind; hinder angles of the pronotum not pointed. Antennæ thickened towards the extremity, with the terminal joints enlarged. These hopping beetles live in the trunks of trees.

* O. micans, Illig. (Plate XII., Fig. 18). This beetle is brown, thickly covered with fine silky pubescence. The abdomen and legs are orange-coloured. It is found in the trunks of oaks and beech trees, where it lives on fungi.

\section{Genus Serropalpus, Payk.}

Body long and cylindrical. Antennæ setiform and half as long as the body in the male, but shorter in the fcmale. 
Legs long and slender. The bectles live in the old wood of pines and fir trees.

* S. barbatus, Schaller. (striatus, Hcllen), (Plate XII., Fig. 19). This is a native of Central and Eastcrn Europe, and has been once or twice taken in Britain. It is brown with silky hair, and slightly striated elytra. Length, 14-20 mm.

Genus Melandrya, Fabr.

Body elongated. Wing-cases slightly convex, expanded in the middle, broader than the pronotum. Antennæ filiform and curved, with the joints only slightly longer than broad. They live in old wood.

* M. caraboides, Linn. (Plate XII., Fig. 20). The elytra are thickly punctate-striate, and the tips of the antenuxe and part of the tarsi are orange. It is found in beech and oak trees. It is common in the London district.

\section{FAMILY XXXV. LAGRIID无.}

Body elongated. Head rounded, and broader than the pronotum, which is cylindrical. Antennæ with short joints.

Genus Lagria, Fabr.

This is the only European genus of the family. The elytra are covered with rough hair. The only British species is:

* L. hirta, Linn. (pubescens, Linn., \&), (Plate XII., Fig. 21). The last joint of the antennæ is longer in the male than in the female. The wing-cases are brownish-yellow and soft, clothed with long shaggy hair. It frequents flowering shrubs.

\section{FAMILY XXXVI. PYROCHROID曆.}

Body somewhat flat. Head broader than the pronotum, which is alniost round, but broader than long. Wing-cases expanded towards the extremity. They live under the bark of trees. 
Genus Pyrociroa, Fabr.

Body angularly expanded behind the eyes. Eyes kidneyshaped. Antennæ with eleven joints, serrated; each joint from the third to the extremity expanded into a projection. They frequent shady, grassy places.

* P. coccinea, Linn. (Plate XII., Fig. 22). The front of the head has a quadrangular depression, rounded behind, and sharply bordered in the male. The beetle is found in birch, walnut, and pine trees, under the decaying bark.

* P. rubens, Fabr. (Plate XII., Fig. 23). This species is smaller than the foregoing, with a deep lunulated depression. The pronotum has a fine median furrow. It is found under the bark of oaks, beeches, and willows, and is much commoner than coccinea.

\section{FAMILY XXXVII. MORDELLID无.}

Pronotum narrow in front, but as broad as the wing-cases behind. Head attached by a neck. Wing-cases attenuated behind, leaving the extremity of the body exposed. Antennic filiform. They are met with on flowers.

Genus Mordella, Linn.

Abdomen drawn out into a point. Claws serrated and dentated. They live on flowers and decayed wood, and are very quick and agile in their motions.

* M. fasciata, Fabr. (Plate XII., Fig. 24). Antennze serrated, with the basal joints yellowish-brown. Elytra black and thickly pubescent, with grey bands. It is found on flowers.

\section{FAMILY XXXVIII. RHIPIDOPHORID在.}

This family resembles the last, but the antennæ are strongly serratcd, pectinated, or fan-like. Some of them arc parasitic on Hymenoptera. 


\section{Genus Metæcus, Gerst.}

Wing-cases covering the entire body, but not meeting at the suture. Hind tarsi with elongated, cylindrical joints.

* M. paradoxus, Linn. (Plate XII., Fig. 25). Wing-cases partially or completely yellow in the male, black in the female. 'The beetle, which is rare in Britain, is found in wasps' nests.

\section{FAMILY XXXIX. CANTHARIDE.}

Body soft, and either winged or not. Head vertical, broadcr than the pronotum, and constricted behind into a neck. The beetles live on trees and grass, and the larvæ are parasitic upon hynienopterous insects.

\section{Genus Meloe, Linn.}

Apterous. Abdomen generally large in the females, and usually not covered by the short elytra. Antennæ filiform or moniliform. They are found in grass. The young sixlegged larvæ hide themselves in flowers, and are carried by bees into the hive, where they feed upon the eggs until it is time for them to change into a footless grub.

* M. proscarabous, Linn. (Plate XII., Fig. 26). This species is black, with a blue shine, and blue-black antennæe and legs. The wing-cases are nearly as long as the abdomen in the male. It is common on paths and in grass in the spring.

\section{Genus Lytta, Fabr. (Cantharis, Linu.)}

These beetles are soft, and provided with wings. The wing-cases are much broader than the pronotum, and somewhat cylindrical. The only British species is:

* L. vesicatoria, Linn., the Blistering Beetle, or Spanish Fly (Plate XII., Fig. 29). This is shining golden, or bluish-green. The beetle appears in large numbers in some years on oaks, 
elder, and privet, and can be known at some distance by its peculiar narcotic smell. The larvæe are parasitic upon Hymenoptera. It is rare in this country.

\section{FAMILY XL。 EDEMERID虑.}

Wing-cases much broader than the short pronotum, elongated, and generally narrowed towards the extremity. Antennæe long and filiform or setiform. The beetles live on flowers, and the larvæ in old wood and the stalks of plants.

\section{Genus Nacerdes, Schmidt.}

Elongated, and of uniform breadth. Elytra flat, with two slight longitudinal striæ. Antennæ with twelve joints in the males, but only eleven in the females. Legs weak, with the femora thickened in the males. They live on flowers.

* N. melanura, Linn. (Plate XII., Fig. 27). Head and prothorax orange. Wing-cases yellow, tipped with black. Scutellum nearly heart-shaped in the male, but almost quadrangular in the female. The beetle lives on flowers, and the larva in old wood. It is found on the sea shore and near the mouths of rivers, in which places it is not uncommon.

\section{Genus EDemera, Oliv.}

Antennæ filiform, with eleven joints. Head strongly produced in front. Pronotum short, wing-cases broadest at the shoulders. Hind femora thickened in the males. They are found on flowers.

* EE. femorata, Scop. (Plate XII., Fig. 28). This beetle is black, with grey hair. It has the base of the antennæe and the elytra yellowish-brown. The hind femora are much thickened in the male. It is found on Umbelliferce, and is especially common on Aegopadium podagraria. 


\section{SECTION III. TETRAMERA.}

(Beetles which have all the tarsi four-jointed.)

\section{FAMILY XLI. CURCULIONID出 (Weevils).}

Head drawn out into a proboscis. Antenne nearly always elbowed and thickened towards the extremity. The Weevils form a very large family of beetles, all of which live upon vegetable food, some being consequently very destructive. The larvæ are footless maggots, which also live upon the leaves, stalks, and roots of plants.

\section{Genus Otiorhynchus, Germar.}

Very convex beetles, usually of a black colour. Antennæ long, the flagellum extending beyond the eyes. Elytra of variable lengtl, oval, and rounded at the shoulders. The species are numerous, and very difficult to distinguish.

* O. unicolor, Herbst (Plate XIII., Fig. 1). This is a shining black beetle. The pronotum is nearly as long as broad, and the elytra are indistinctly punctured. It is found on wooded slopes.

* O. ligustici, Linn. (Plate XIII., Fig. 2). Black, more or less thickly covered with grey scales. The proboscis has a raised median stria. It lives on the young shoots of the peacl trees and on vines. It is very rarc in England.

\section{Genus Phylíorius, Schönherr.}

These are winged beetles, with a very short, stout proboscis, and rather long and slender antemne, the first two joints of 

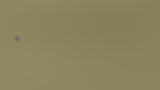

18

$y^{2}=$

$=$

$+\frac{1}{1}$

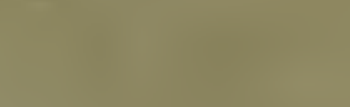

(1)

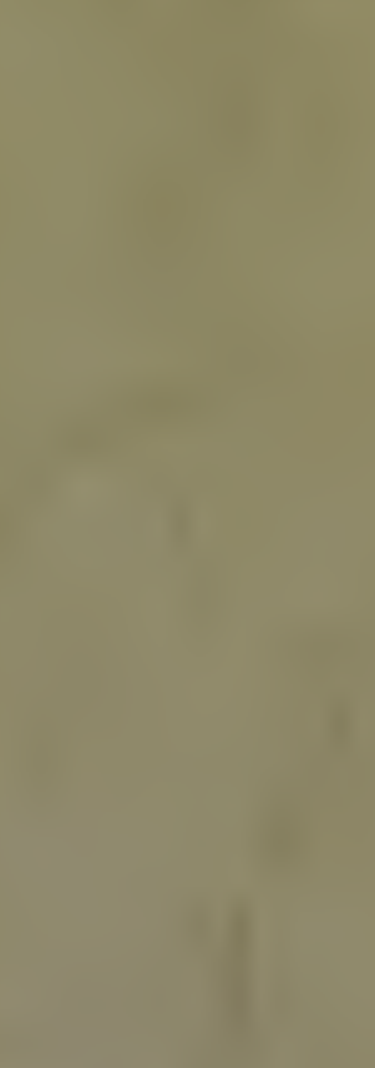

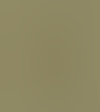

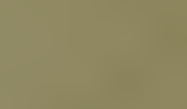

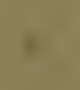

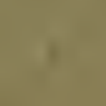

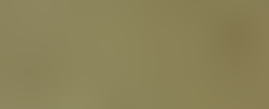
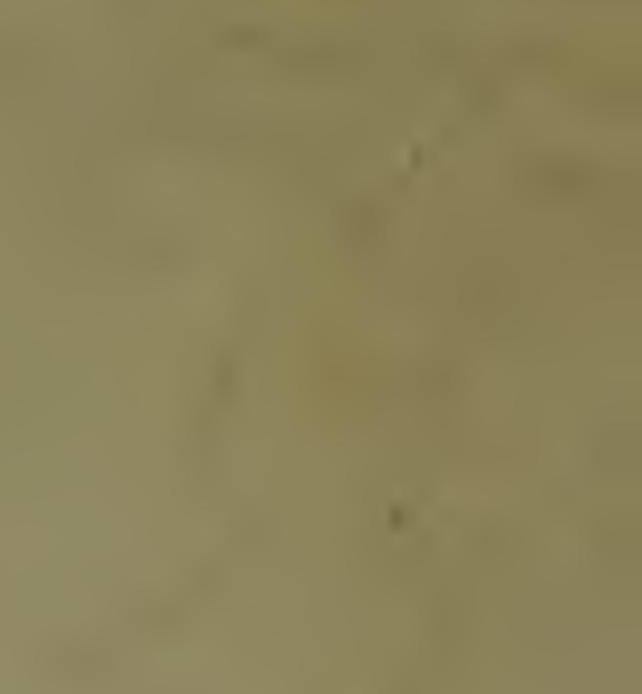

1

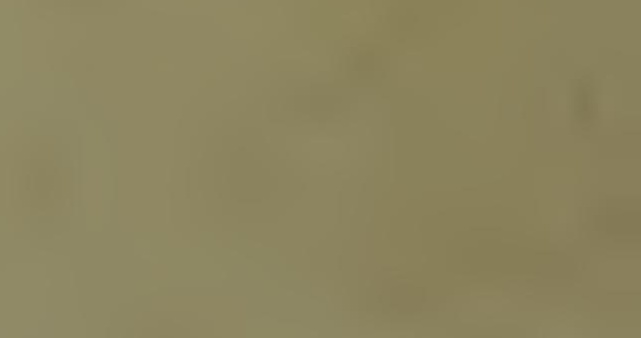

I
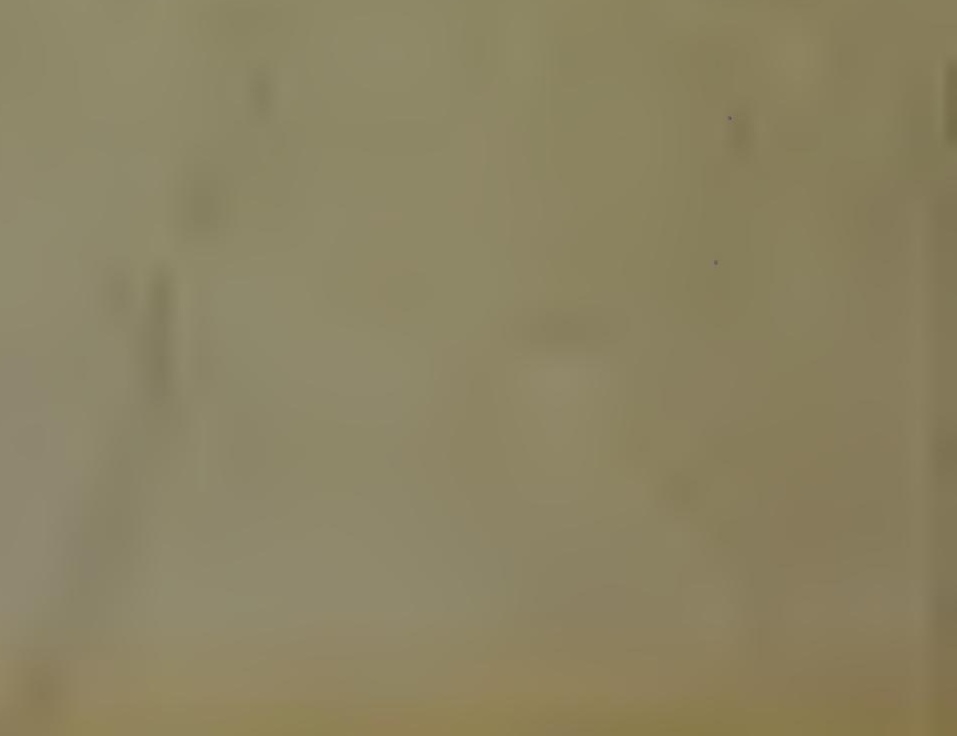

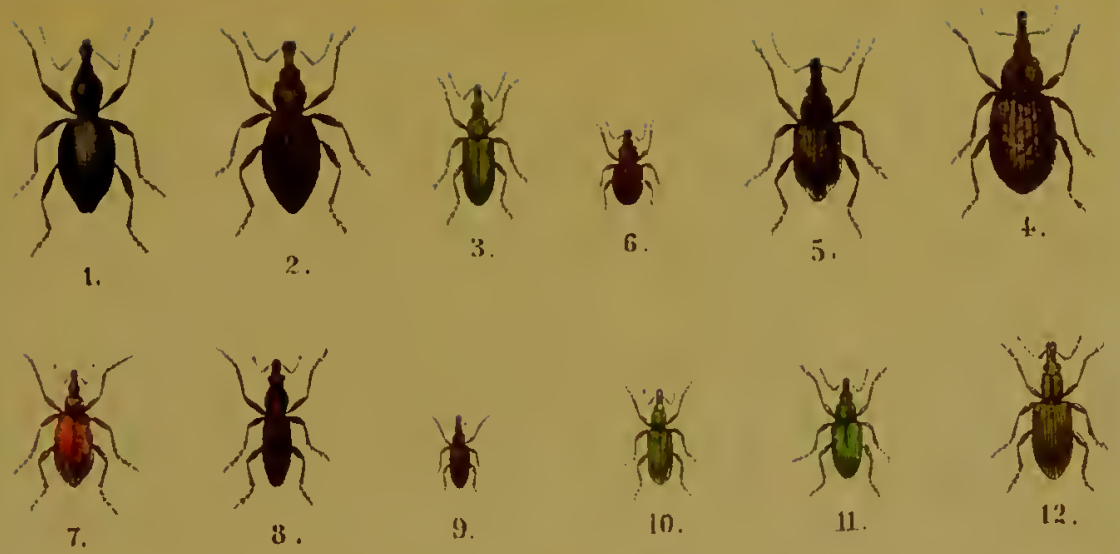

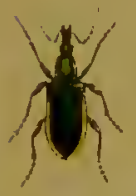

13.

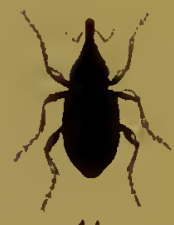

14.

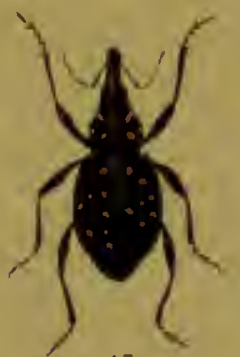

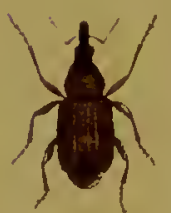

16.

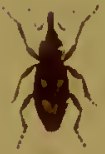

17.

W

18.
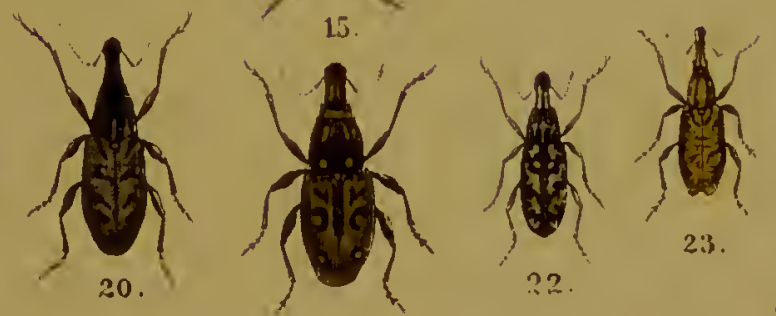

fint

23.

21.

2.2.

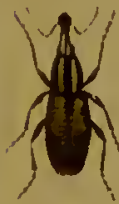

25.

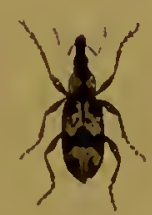

26.

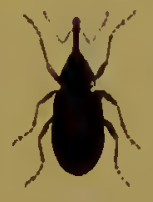

27.

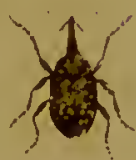

213

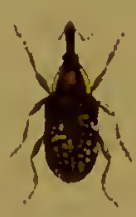

29.

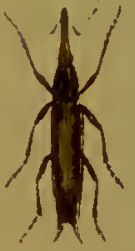

30.
W

3.3.
31.

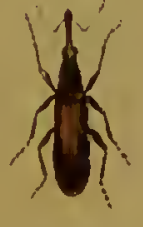

32.

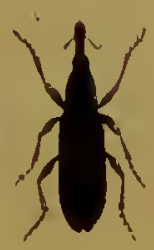

31.

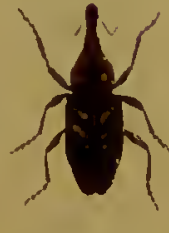

35.

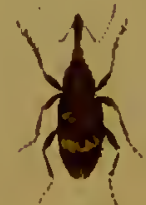

36.

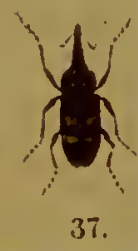



which are elongated and the rest conical. They are found, often in large numbers, on various bushes, which they denude of their leaves.

* P. calcaratus (Plate XIII., Fig. 3). This species is black, clothed with long, grey, yellowish-green, or golden scales. The fenora are distinctly toothed. It is coinmon in woods.

Genus Liophløevs, Gern.

Wing-cases broad, truncated in front. Antennæ rather long. and slender, flagellum seven-jointed. The femora are clavate, obtusely dentated. They live on flowering shrubs.

* L. mubilus, Fabr. (Plate XIII., Fig. 4). Black, thickly punctured, and densely covered with grey scales. Antenne reddish-brown, with the exception of the club. It is common on roads and on flowering bushes. Length, $8-11 \mathrm{~mm}$.

Genus Barynotus, Germ.

These are wingless beetles, with the proboscis shorter than' the pronotum, and rather thick. The antennæ are somewhat slender, with the flagellum reaching as far as the middle of the eyes; the first two joints are elongated, and the rest short. They are found generally under stones, but occasionally on bushes.

* B. obscurus, Fabr. (Plate XIII., Fig. 5). This species is. black, with brown and grey scales. The wing-cases are indistinctly punctate-striate. It is a common species.

Genus Strophosomus, Schönh.

Apterous bcetles, scaly, with erect hair or bristles. The proboscis is short and angular, flat above. The antennx are rather slcnder, with the flagcllum reaching to the hind margin of the eyes. They are found on sandy, grassy places, under stones, and rarely on bushes. 
* S. coryli, Fabr. (Plate XIII., Fig. 6). This is a black beetle, with stout pitchy-brown antennæ and legs. The wingcases are punctate-striate, with grey and brownish scales. It is very common on hazel-bushes.

\section{Genus SciapinLUs, Schönl.}

Elongated, oval, or nearly globular beetles. The proboscis is short and rather flat above, emarginate at the extremity. The males are for the most part much smaller and longer than the females. They are found in the grass in sandy, sunny places.

* S. (Polydrusus) micans, Fabr. (I'late XIII., Fig. 7). Elytra uniformly punctate-striate, with shining coppery-golden scales. It is common on the young leaves of trees.

\section{Genus BrachỳderEs, Schönh.}

Apterous. Elytra very much produced, femora undentated; front tibix not curved at the tip. They are foumd on young fir-trees.

B. incanwis, Linn. (Plate XIII., Fig. 8). Elongated, pitchybrown, with shining metallic scales. Antemnæ slender, reddishbrown. It is found in various parts of the Continent.

\section{Genus Sitones, Schönh.}

These are winged beetles, with long wing-cases, having obtuse shoulder angles. The antennæ are somewhat slender, the first joint elongated and stouter than the rest, the second somewhat louger than the first, and the succeeding joints short. They are found on low plants and arborescent plants.

* S. lineatus, Linn. (Plate XIII., Fig. 9). Black, clothed above with brown, and beneath with grey or greenish scales. The elytra are punctate-striate, with the alternating interstices frequently whitisl. It frequents clover fields, and is a comma: and destructive pest. 
Genus Metallites, Germ.

Body soft and winged. Proboscis very short, quadrangular, but flattened, with a deep groove for the antennæ. They live on bushes.

M. mollis, Germ. (Plate XIII., Fig. 10). This is a black or brown beetle, with yellowish-brown legs and antennæ. The elytra are punctate-striate, with green scales. It is found on young fir-trees, and is a native of South-Eastern Europe.

Genus Polydrusus, Schönh.

This genus is very closely allied to the preceding, and the species are also winged. The proboscis is short and more or less round. They live on shrubs.

* P. sericeus, Schall. (splendidus, Herbst), (Plate XIII., Fig. 11). This is a black beetle, clothed with bluish or grconish scales. The legs and tarsi are pale yellowish-brown. It is very rare in this country.

\section{Genus Tanymecus, Germ.}

Body elongated and winged. Pronotum longer than broad. Antennæ rather slender, the first two joints being elongated, and the rest short. The proboscis is short and quadrangular. They are found on low plants.

* T. palliatus, Fabr. (Plate XIII., Fig. 12). This species is black, clothed with fine brownish-grey scales above, and pale grey beneath. In the female the first and second abdominal segments are grooved. It is found on nettles, thistles, and turnips, and is rather common in the neighbourhood of London.

\section{Genus Chlorophanus, Dalm.}

Winged. Flagellum of the antennie not reaching the eyes. Tibire expanded inwards at the tip into a long, sharp, horny hook. They are found on bushes and trees. 
C. viridis, Fabr. (Plate XIII., Fig. 13). This beetle is clothed with green scales above, and witl yellow on the sides of the pronotum and elytra, the latter with a short spine. It is common on alder, willow, and hazel in most parts of the Continent.

\section{Genus Minyops, Sehönh.}

Apterous beetles, with small, elongated, oval eyes placed laterally. The proboscis is rather stout and long, slightly bent. The antennæ are short, with the first joint elongated, the second scarcely longer than the third, and the remaining ones very short.

M. variolosus (Plate XIII., Fig. 14). Black, with numerous depressions, more or less covered with a grey dusting. It is a native of Southern France and Germany, where it lives under stones.

Genus MoLyTES, Schönl.

Apterous; either bare or spotted with yellow scales. The elytra have the shoulders rounded. The flagellum of the antennæ does not extend to the eyes. Scutellum distinct. It is found on paths, in grass, and under stones.

* M. germanus, Linn. (Plate XIII., Fig. 15). Wing-cases and pronotum with numerous depressed yellow-scaled spots. The last abdominal segment is simple in the female, but slightly depressed in the male. It is found in chalky places, and is rare and local.

\section{Genus Plisthus, Germ.}

Apterous. Elytra with a common concavity at the base, with obtusely projecting shoulders. Scutellum very indistinctly seen. Antennæ somewhat slender, the first two joints elongated, and the others knot-like. They are found under stones. 
P. sturmii, Germ. (Plate XIII., Fig. 16). Pitchy-black, finely hairy. Pronotum granulated. Elytra strongly punctatestriate, with small elevations. It is a mountain species, inhabiting the southern portions of Central Europe.

Genus Alophos, Schönh.

This genus closely resembles the last, but has the flagellum of the antennæ not nearly extending to the eyes. The body is scaly and without wings. The only British species is:

* A. triguttatus, Fabr. (Plate XIII., Fig. 17). Black, clothed with grey and brown scales. Elytra striated, each with two lighter scaly spots. It is not uncommon, especially in sandy and chalky loealities, under stones, \&c.

Genus Hypera, Germ. (Phytonomus, Schönh).

Some of the species are winged, and others not. Antennæ slender, seven-jointed, the first two joints more or less elongated, the others almost moniliform. The hind margin of the pronotum is slightly rounded. They live on plants.

* H. punctata, Fabr. (Plate XIII., Fig. 18). This beetle is winged, and has grey and brown scales. The sides of the wing-cases and the under surface are thickly clothed with greyish-white scales, and the antennæ and tibir are brownishred. It is common, especially in dry, sandy places.

H. variabilis, Herbst (Plate XIII., Fig. 19). This species is black, with ashy-grey scales. The pronotum has three pale longitudinal bands, and the elytra have a large brown patch on the front of the suture. The antennæ and tibiæ are dull red. It is common on leguminous plants.

\section{Genus Cleonus, Schönh.}

Body elongated, sealed, and winged or wingless. Proboscis short, with deep gronves for the antemne, curved strongly duwnwards. Antenne rather short and stout, the Hagellum 
not reaching the eyes. They are found under stones, and the larvæ live in the stems and roots of low plants.

* C. sulcirostris, Linn. (Plate XIII., Fig. 20). This beetle is rather thickly clothed with grcy pubescence. The wing-cases are slightly punctate-striate, with two oblique, dark, denuded bands. The larvæ live in the stalks and roots of thistles, and are sometimes destructive to beet. It is found chiefly near the coast.

C. ophthalmicus, Rossi. (Plate XIII., Fig. 21). This species is clothed with whitish-grey or greyish-yellow hair. The elytra have two lighter-haired spots on each side. Length, 12-14 mm.

C. marmoratus, Fabr. (Plate XIII., Fig. 22). This species is covered with brown hair, and the head has a depressed transverse stria behind the eyes. The elytra are chequered with white. It is found in France and Germany.

C. trisulcatus, Herbst (Plate XIII., Fig. 23). This species closely resembles $C$. sulcirostris, but has the middle furrow of the proboscis narrow. The larva lives in the stalks and roots of Chrysanthemum. It is a native of many parts of Central Europe.

C. obliquus, Fabr. (Plate XIII., Fig. 24). This is a grey beetle, with a brownish proboscis. The elytra have two oblique, blackish bands. It is a native of some parts of Central and Southern Europe, where it lives on the pine.

C. cinereus, Schrank. (Plate XIII., Fig. 25). This beetle is thickly clothed with greyish pubescence. The pronotum has four longitudinal, whitish stripes. The elytra are black, punctured, and spotted. It is found in various parts of the Continent.

* C. albidus, Fabr. (Plate XIiI., Fig. 26). The beetle derives its name from the whitish pubescence with which it is clotheu. 
The elytra have two bands, which arc denuded and taper towards the extremity. It is found on pine-trees.

Genus Larinus, Germ.

Body oval, winged, and usually pubescent. The proboscis is rather long and rounded. The antennæ are somerwat long and seven-jointed, the first two joints being scarcely longer than those following. They are found on thistles, and the larvæ in the flower-heads.

L. sturnus, Schall. (Plate XIII., Fig. 27). Proboscis with a raised line down the middle. Elytra very uniformly spotted with grey. It is a native of various parts of the Continent, living on Centaurea scabiosa.

L. jaccec, Fabr. (Plate XIII., Fig. 28). This closely resembles the last species, but is smaller, and has not the median furrow on the proboscis. The elytra are short and oval. It is found on thistle-heads, and is a native of Southern and the southern parts of Central Europe.

L. pollinis, Laich. (Plate XIII., Fig. 29). This beetle is similar, but the proboscis is only half as long as the pronotum. The wing-cases are covered with yellowish-brown scales. The abdomen has black linear spots and a yellow spot on the side. It is found in various parts of the Continent.

\section{Genus Lixus, Fabr.}

Body long and cylindrical. Proboscis rather long and roundcd. Antenne inserted near the middle of the proboscis. Both the beetles and their larvæ live in the stems of Umbelliferce, \&c.

* L. paraplecticus, Linn. (Plate XIII., Fig. 30). Black, dustcd with grcenish-yellow. Femora slender, not thickened. The larvie live in the stems of umbelliferous plants, and are espccially partial to water-hcmlock. It is a rare species. 
* L. angustatus, Fabr. (Plate XIII., Fig. 31). Black, with greyish pubeseenee, and dusted with greenish. Wing-eases depressed at the base, punetate-striate. It is a larger beetle than the last speeies. The larva lives in the stems of mallow and thistle.

* L. bicolor, Oliv. (Plate XIII., Fig. 32). This speeies is dusted with rusty-brown. The elytra, which are not depressed at the base, are punctate-striate. It is found on walls in early spring.

\section{Genus Lepyrus, Germ.}

Body elongated oval, sealy, and provided with wings. Seutellum distinet. Front margin of the pronotum very slightly coneave in its whole breadth. They are found on bushes.

L. colon, Linn. (Plate XIII., Fig. 33). Blaek, with grey seales and hair. Elytra with a lighter sealy spot in the middle. Abdomen with a row of white spots on eaeh side. It is found on willows in Southern and the southern portions of Central Europe.

* L. binotatus, Fabr. (Plate XIII., Fig. 34). This speeies closely resembles the foregoing, but is a shorter oval, and has no spots on the abdomen. It is found in woods and damp meadows, but is very rare in this eountry.

Genus Hylobius, Germ.

Wing-eases short, cylindrieal, and entirely eovering the abdomen. Pronotum scareely longer than broad, and greatly narrowed in front. Front inargin of the prosternum deeply ineised. Proboseis somewhat curved, and slightly thiekened towards the extremity. They live on pines, the larvæe under the bark of the old stumps.

* H. abietis, Linn. (Plate XIII., Fig. 35). Black, with yellowish-grey seales. The elytra have from two to four irregularly-sealed yellow maeular bands. The beetles are 
found on the shoots and under the bark of young fir-trees, which they sometimes damage considerably.

Genus PIssodes, Germ.

Elytra with a distinct callosity before the tip, cylindrical. Prosternum simple. Proboscis slightly curved. They are found on the trunks of pines and firs, and the larve live under the bark.

P. picex, Illig. (Plate XIII., Fig. 36). Brown, with raised interspaces on the elytra, and yellowish bands. The proboscis is reddish-brown, thickly punctured. It lives in the white pine, to which the larvæ are very destructive. It is found in Germany and Switzerland.

* P. pini, Linn. (Plate XIII., Fig. 37). This species is somewhat lighter. The elytra have a deep quadrangular depression, and a narrow yellow transverse band, as well as several spots of the same colour. It is found on fir-trees, in the North of England and in Scotland.

Genus GRYPIDIUs, Schönh.

Wing-cases oval, and almost twice as broad at the base as the pronotum. Front tibiæ with scarcely visible hinder angles. Proboscis longer than the head and pronotum, rounded and curved, They live in meadows.

* G. equiseti, Fabr. (Plate XIV., Fig. 1). This beetle is pitchy-black, with whitish and bluish-grey scales. The elytra are dilated behind the middle, and both are marked witl two white spots. It lives in damp meadows on Equisetum.

\section{Genus Erirhinus, Schönh.}

Body usually elongated oval. Elytra completely covering the abdomen. Proboscis long and slender, with a long furrow for the antenne. Front margin of the pronotum even and straight beneath. They live on aquatic plants and on trees. 
* E. tortrix, Linn. (Plate XIV., Fig. 2). Brownish-yellow, with grey pubescence. Elytra slightly punctate-striate. It is found on beech-trecs and willows.

\section{Genus Balaninus, Germ.}

Body broadest in the middle. Proboscis very long and slcncler, often as long as the entirc body. Wing-cases elongated, heart-shapcd, the pygidium morc or less projecting. They live on bushes, and drop to the ground at the least movement.

* B. nucum, Linn., the Nut Weevil (Platc XIV., Fig. 3). This spccics is covcred with grey scales. The proboscis is only slightly curved in the male, but strongly curved in the female. The larva of this beetle is the white worm found in hazcl-nuts. One or two allied species infest acorns. and oak-galls.

Genus Anthononus, Germ.

Body expanded bcyond the middle, winged. Scutellum somewhat raised. Eyes projecting. They arc small beetles which live on flowers and bushes, and often cause considerable damage to these.

*A. pomorum, Linn. (Plate XIV., Fig. 4). This beetle is covered with fine grey pubescence, with blackish markings. on the elytra. It hibcrnates in the crevices of trees, and lays its $\operatorname{egg} 3$ in the buds of the apple. The larva lives on the stamens, and is much dreaded on account of its ravages.

Genus Orichestes, Illig.

Body winged. Scutellum sinall but distinct. Hind fernora thickened. 'They are for the most part small specics which live on leaves, and have the power of jumping. The larva ıninc the leaves. 


* *

* $* * * *$

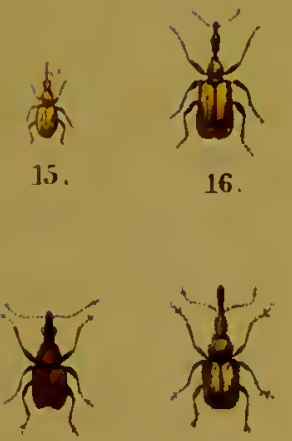

17.

18.
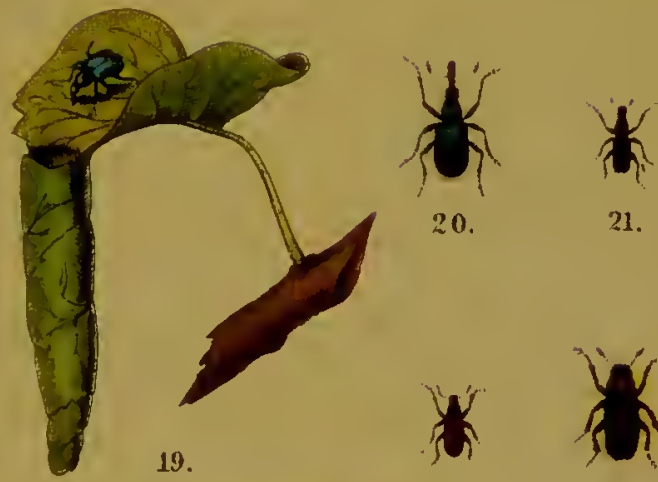

*

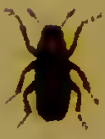

22.

23.

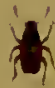

21.

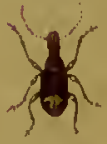

29.

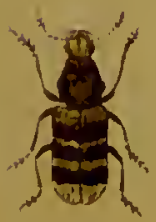

28.

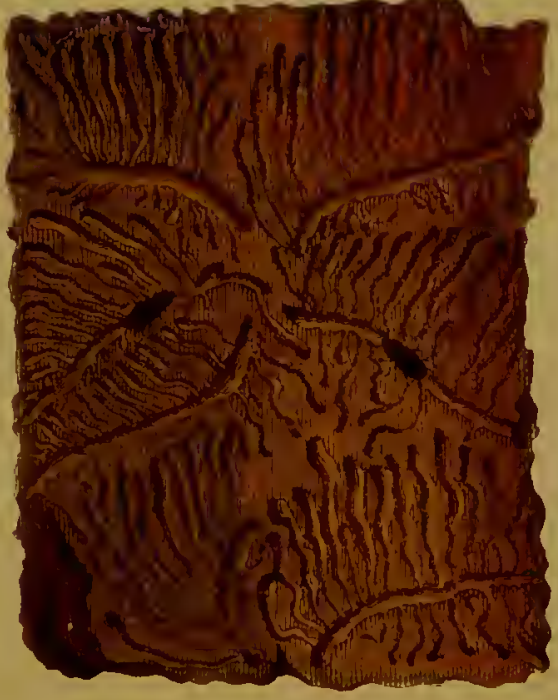

25.

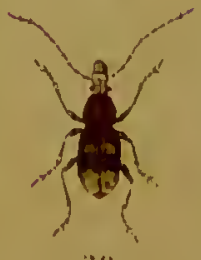

31). 

* O. quercus, Linn. (Plate XIV., Fig. 5). Yellowish-brown, with grey pubescence. Eyes and sternum black. Elytra with a large spot. The larva makes brown spots in very young oak-leaves, as it feeds on the chlorophyll of the lcaf.

* O. fagi, Linn., lives on beech-trces, which it treats in the same way.

\section{Genus Cronus, Clairv.}

Body roundish. Pronotum short. Wing-cases broad and quadrangular. Proboscis slender and filiform. Eyes not proninent, situated on the sides in front. The species live on various low plants.

* C. scrophularice, Linn. (Plate XIV., Fig. 6). This species is covered with grey pubescence, and has the raised interspaces chequered with black and white. It feeds on figwort.

* C. verbasci, Fabr., is very similar, but has yellowish hair ou the sides. It lives on mullein.

\section{Genus Gymnetron, Schönh.}

Elytra short, generally slightly longer than the breadth at the shoulders. Shoulders obtusely angled. Proboscis slender and rounded, filiform. They live on low plants.

G. teter, Fabr. (Plate XIV., Fig. 7). Oval; black, with yellowish-grey pubescence. Femora with a club-like expansion towards the extremity. It lives on snap-dragon, and is a native of Southcrn Europe.

\section{Gcnus Cryptorhyxcirus, Illig.}

Elytra almost oval, greatly narrowed at the extremity, and covering the wholc of the abdomen. The proboscis is nearly as long as the head and pronotum, and is slcuder, rounded, and moderately curved. The only British specics is:

*C. lapathi, Linu. (Plate XIV., Fig. 8). This is a black or 
pitchy-brown beetle, with raised black scales on the wingcases. It lives on alder and willow, the larva feeding in the wood of the trces.

\section{Genins Ceuthorhyncius, Schönh}

Body stout. Wing-cases much broader at the base than the pronotum. Proboscis slender, filiform, and curved. Antenna inserted a little in front of the middle of the proboscis. They are found on flowers and on walls, \&c.

* C. echii, Fabr. (Plate XIV., Fig. 9). Black, with greyishbrown scales above and white beneath. It lives on viper's bugloss.

* C. sulcicollis, Gyll., another species of this large genus, is found in root-galls of rape, \&c.

\section{Genus Baridius, Schönh. (BarIs, Germ.)}

Elongated, rather cylindrical bcetles, with the pronotum long and narrowed at the extremity. Eyes placed at the sides. Scutellum small and round. They live on various plants.

B. cuprirostris, Fabr. (Plate XIV., Fig. 10). Shining light green. Proboscis punctured. It is found in cabbage stalks, and is a native of Southern and parts of Central Europe.

\section{Genus Calandra, Clairv.}

Body smooth and elongated. Club of the antennæ long, oval, and blunt-pointed. Proboscis slender and filiform. Front tibiæ with small dentations on the inner sidc. They live on grain.

* C. granaria, Linn., the Corn Wcevil (Plate XIV., Fig. 11). This species is brown, rarely black, with rustyred legs and antennæ. It is found in granaries and bakers' shops. The larva is black. 
Genus Cossonus, Fabr.

Body smooth and long. Antenna rather thick, and inserted beyond the middle of the proboscis. Elytra more than twice as long as broad. They are found under decayed bark.

* C. linearis, Linn. (Plate XIV., Fig. 12). Pitchy-black, with rusty-red legs and antenna. Not unfrequently the beetle is entirely brown. Elytra flattened on their front half. It lives in the wood of willows and poplars.

Genus Magdalinus, Schönh.

Elytra cylindrical, rounded at the base, with a raised border, leaving the pygidium free. Antennæ elongated, with the flagellum clubbed at the extremity.

* M. pruni, Linn. (Plate XIV., Fig. 13). This is a black beetle, with a long, straight proboscis. The antennæ are reddish-ochreous, except the club. It is common on fruit trees, and the larva in dead wood.

\section{Genus Apion, Herbst.}

Head and eyes nearly as broad as the pronotum. Antennæ rather slender, with an oval, tapering club. Proboscis awlshaped and pointed. There are a great many of these sinall beetles, and they are difficult to distinguish. They live on bushes and low plants, and the larvæ in the seeds, leaves, and stalks.

* A. pomonce, Fabr. (Plate XIV., Fig. 14). Black, with blue wing-cases. Proboscis generally expanded on the inder surface. It is coinmon on shrubs and fruit trees, living on the flowers.

* A. miniatum, Schönh. (Plate XIV., Fig. 15). This species is blood-red, with black eyes and a rather stout proboscis. The elytra are elongated oval, and deeply punctate-striate. It lives in galls growing on willows and aspen. 
Genus Apoderos, Oliv.

Body rounded. Head distinctly narrowed into a neck behind, and hanging as if on a stalk. Elytra wider than the pronotum. They are found on shrubs.

* A. coryli, Linn. (Plate XIV., Fig. 16). This beetle is red or orange, with a black head, anteunæ, and scutellum. It is found on hazel, from whose leaves it constructs a roll, in which the larva lives.

\section{Genus AtTelabus, Linn.}

This genus closely resembles the last; but the species are stouter, and the head is only slightly, if at all, attenuated behind the eyes. They live on oaks.

* A. curculionoides, Linn. (Plate XIV., Fig. 17). Black, with the elytra dark red, as in $A$. coryli, but with the basal joints of the antennæ generally red. It lives on oak-trees. and has similar habits to $A$. coryli.

\section{Genus Rhynchites, Herbst.}

This resembles the last genus, but the front tibir are not toothed on the inner side. The beetles live on bushes and trees, and the larve in fruits, shoots, or rolled leaves.

* R. bacchus, Linn. (Plate XIV., Fig. 18). Reddish-purple, with a golden shine. The pronotum, antennæ, and tarsi are entirely blue-black. It is found in spring on apple and sloe, eating the blossoms first and then laying its eggs in the unripe fruit, in which the larvæ live. It is very rare in Britain.

* R. betuleti, Fabr. (Plate XIV., Fig. 19). Blue or green, without pubescence, larger and more finely punctured than

* $R$. populi, Linn., which lives on the poplar. It prepares rolls of leaves on apple and pear trees, in which the larvæ live.

* R. pubescens, Fabr. (Plate XIV., Fig. 20). Blue and pubescent. It is found on young oaks. 


\section{FAMILY XLII. SCOLYTIDE (BOSTRYCMIDAs).}

Body cylindrical, usually truncated behind. Head morc or less retracted into the pronotum, not drawn out into a proboscis. Antennæ with a large thick club. They live o:1 trces, and often do considerable damage.

\section{Genus HyLastes, Erichs.}

Tips of the elytra not convex. Antennæ filiform, with the club rounded and compressed. They live under the bark of pines.

* H. ater, Payk. (Plate XIV., Fig. 21). Black, with the end of the proboscis pressed in. Antennze and tarsi reddish-brown. It is common under the bark of pine-trees.

* H. (Hylurgus) piniperda, Linn. (Plate XIV., Fig. 22). Black, with brown wing-cases, and rusty-red antennæe and tarsi. It lives under the bark of pine-trees. The larvie live in the shoots, which become brown, and then fall off.

H. (Dendroctonus) micans, Kug. (Plate XIV., Fig. 23). Black, brown, or yellowish-brown, clothed with long greyishyellow hair. The elytra are granularly punctured. It is found under the bark of pine-trees, and is a native of Northern and parts of Central Europe.

*H. (Scolytus) pruni, Ratzeb. (Plate XIV., Fig. 24). Shining black, with the front and hind margins of the pronotum and the elytra brown. It is found under the bark of old plum and other fruit trees.

Genus Bostrychus, Fabr. (Tomicus, Latr.)

Tips of the elytra depressed. Antenna filiform, five-jointed, with a largc ringed terminal club and five-jointed flagellum. They are found in or under the bark of trees and shrubs. 
B. typographus, Linn. (Platc XIV., Fig. 25). Brown, with four teeth on each of the elytra behind. It lives under the bark of fir-trees. It is found in most parts of Europe.

* B. (Dryocctes) autographus, Ratzeb. (Plate XIV., Fig. 26). Pronotum narrowed behind, coarsely and extensively puncturcd. It is a native of parts of Northem and Ccntral Europe, and is often very destructive in fir-woods.

* B. (Xyloterus) domesticus, Linn. (Plate XIV., Fig. 27). This is a black species, with the elytra brownish-yellow and nearly twice as long as broad. It lives in the dead wood of beech, sycamore, lime, and birch trees.

\section{FAMILY XLIII. ANTHRIBIDE.}

Proboscis usually broad. Antennæe eleven-jointed and frequently clubbed. Tarsi not distinctly four-jointed, because the third joint is hidden in the deeply-cleft second. The elytra leave the pygidium uncovered. They live on wood and in bushes.

\section{Genus Platyrhinus, Clairv.}

Eyes round and very prominent. Front of the head depressed. Proboscis very broad and flat. Elytra flattened above.

* P. latirostris, Fabr. (Plate XIV., Fig. 28). This is elongated, and covered with thick grey hair, the tips of the elytra, sternum, and abdomen being white. It is found in the stumps of old beeches and elms. It is rare in this country.

* P. (Tropideres) albirostris, Herbst (Platc XIV., Fig 29). Black, sprinkled with grey, with the proboscis and a large spot at the end of the elytra white. It is found in the stumps of oak, lime, and beech trees. It is extremely rare. 
Genus Anthribus, Fabr.

Elongated, with kidney-shaped eyes. The front margin is distinctly concave. The antennie are very long in the males, but only half as long in the females. The only British species is:

* A. albinus, Linn. (Plate XIV., Fig. 30). Blackish-brown, with greyish-brown pubescence. The proboscis, front of the head, and a spot on the elytra, are white. The extremity of all the joints of the antennæe is white in the male, but in the female only the third joint has this colour. It lives in beech and elm trees. It is local, and as a rule rare.

\section{FAMILY XLIV. CERAMBYCID正 (Longicornia).}

Body long, and rather cylindrical than flattened. They are mostly large and handsome beetles, with setiform or filiform antennæ, which are usually as long as, or longer than, the body. The legs are slender, with four-jointed tarsi and broad, spongy pulvilli. These beetles live on flowers and on wood, and their elongated larvæ live in the stems and branches of trees.

\section{Genus Spondylis, Fabr.}

Cylindrical, with the pronotum narrowed in front and behind. Antennæ moniliform, and half the length of the body.

S. buprestoides, Linn. (Plate XV., Fig. 1). This is a black beetle, thickly and irregularly punctured. It is found in fir-woods, and the larva lives in old fir-stumps.

\section{Genus Ergates, Serv.}

Antennæe setiform. Latcral border of the pronotum finely notched, or toothed, with a small lateral spine. 
E. fabcr, Linn. (Plate XV., Fig. 2). This beetle is pitchyblack, and has the first joint of the antennæ much thickened. The pronotum is finely notched in the male, and finely dentated in the female. The larva lives in the dead wood of old pines, willows, and poplars.

\section{Genus Prionus, Geoff.}

Pronotum with three large tecth on eaeh sidc. Antennæ serrated in the males. Wing-cases broad and flattened. The only British species is:

* P. coriarius, Linn. (Plate XV., Fig. 3). This is pitchyblack, with the sternum thickly eoated with grey pubescence. The wing-cases are coarsely punctured. It is found on bcech and oak trees, and the larva lives in the decayed wood.

\section{Genus Ceranbyx, Linn.}

Head bowed. Pronotum with a distinct tooth on the sides, roughly granulated transversely. Antennæ longer than the body in the males, and as long as the body in the females. They are found on oak-trees.

C. heros, Fabr. (ccrdo, Linn.) (Plate XV., Fig. 4). Shining black, with the tips of the antennæe and the under surfaee covered with fine, grey pubeseence. The larva lives in healthy oak-trees, and excavates large passages. The beetle fceds at night on the sap. It is found in various parts of the Continent.

C. cerdo, Scop. (scopolii, Fuessl), (Platc XV., Fig. 5). This species is shining black, with the elytra not narrowed towards the end. It is found in beech and oak in various parts of the Continent.

\section{Genus Purpuricenus, Serv.}

Antennæ sparsely hairy, setiform in the males, with twelve joints, and longer than the body. Those of the fcmale are 



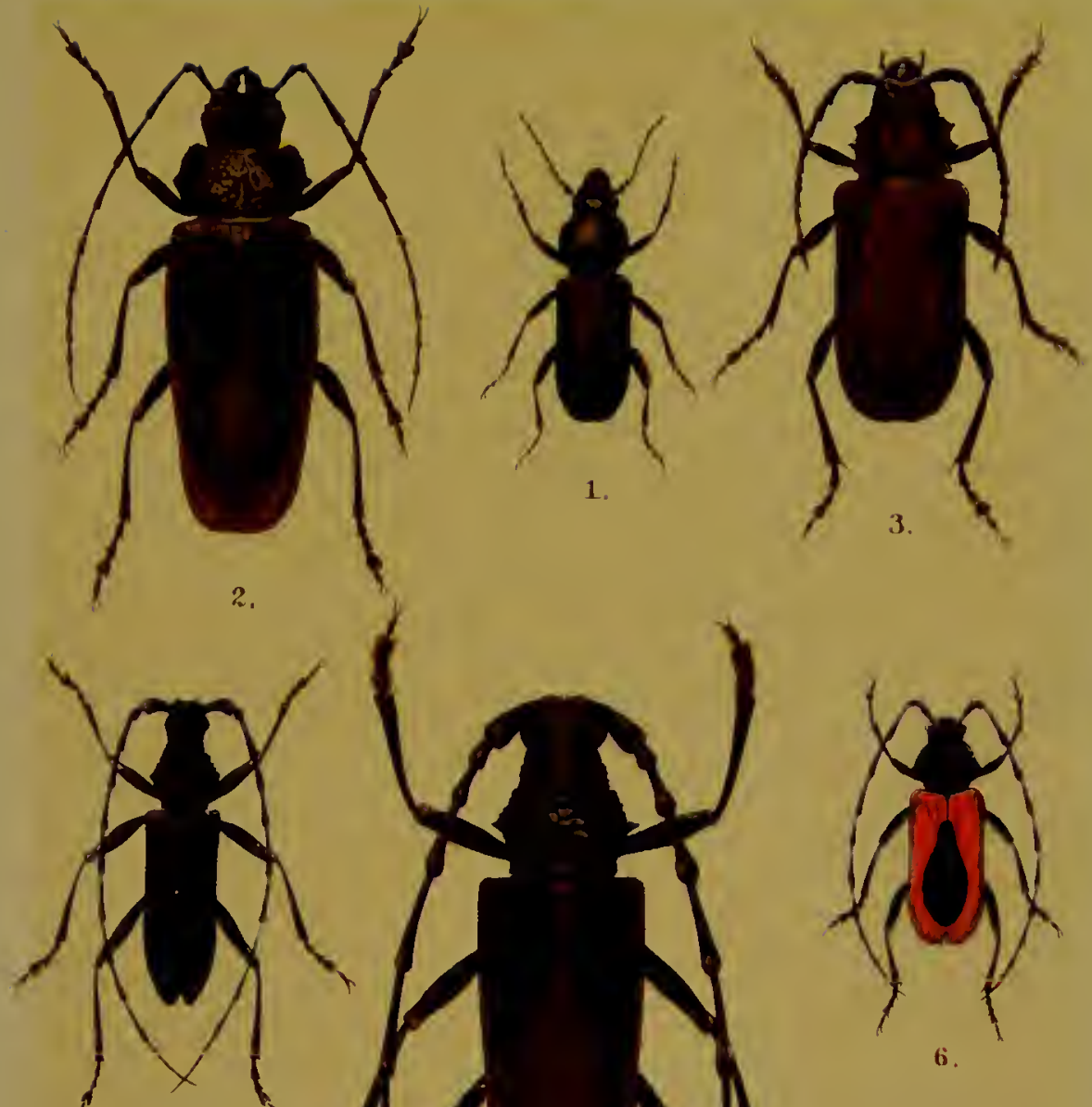

5.
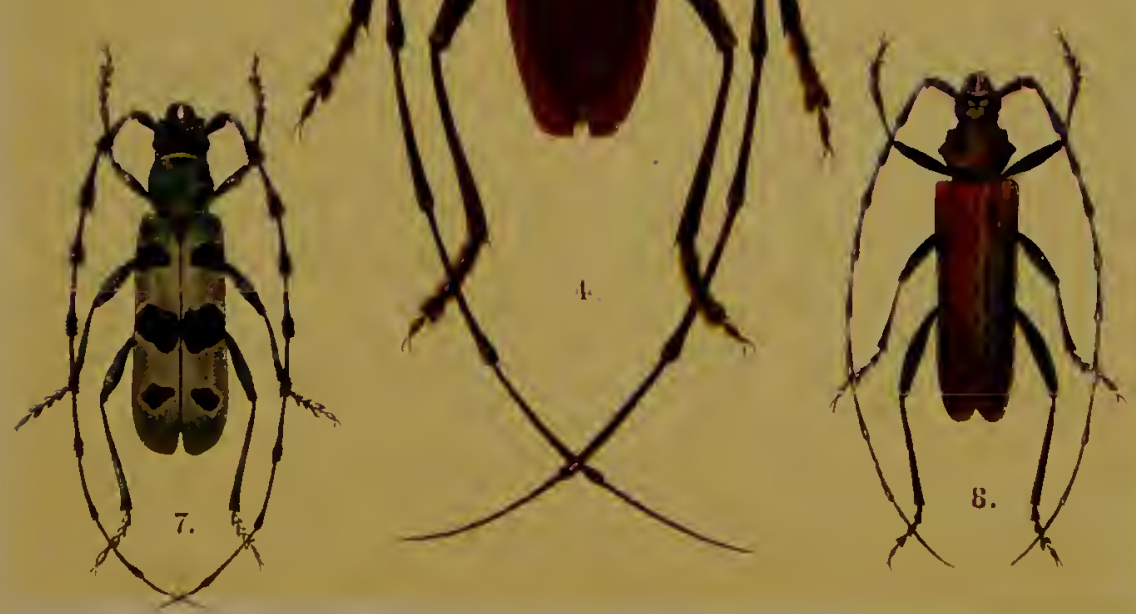

composed of only eleven filiform joints, and are not longer than the body. They live on trecs.

P. Koehleri, Fabr. (Plate XV., Fig. 6). Pronotum entirely black, or black with a larger or smaller yellow spot on each side. The larva lives in diseased apricot-trees. It is a native of Southern Europe.

\section{Genus Rosalia, Serv.}

Antennæ eleven-jointed, setiform, slightly longer than the body in the females, but much longer in the males, with tufts of hair.

R. alpina, Linn. (Plate XV., Fig. 7). This beetle is covered with fine bluish-grey pubescence with black spots. It lives on beech-trees, and the larva in the wood. It is found in mountainous districts in several countries on the Continent.

Genus Aroura, Serv.

Antcnnæ eleven-jointed, setiform and bare, longer than the body in the male, but shorter in the female. The only species is common on willows.

* A. moschata, Linn., the Musk Beetle (Plate XV., Fig. 8). This beetle is blue, green or coppery, very closely and finely punctured. It emits a strong smell of musk, and may frequently be found crawling on decaying willows.

\section{Genus Callidiom, Fabr.}

Antennæe eleven-jointed, filiform or setiform. Eyes strongly emarginate. Pronotum roundish. The femora are expanded in a club-like manner. Thesc beetles arc found on flowers and trcc-trunks, and the larve on old tree-stumps.

* C. violaceum, Linn. (Plate XVI., Fig. 1). This is light blue, violet, or greenish-blue above, darkcr beneath, with black legs and antcnnæe. It is found under the bark of pine and alder. 
- C. sanguineum, Linn. (Plate XVI., Fig. 2). Red, with a velvety surface. It is found on beech, hornbeam, oak, and clrestnut trees. It is excessively rare in Britain.

C. unifasciatum, Fabr. (Plate XVI., Fig. 3). Reddishbrown, the hinder portions of the elytra darker, with a white transverse band. It is a South European species.

C. rufipes, Fabr. (Plate XVI., Fig. 4). Dark blue and hairy, with the under surface blackish. The base of the antennie and the legs are orange. It is found in Southern Europe and in South Central Europe.

* C. variabile, Linn. (Plate XVI., Fig. 5). This species is either uniform blue, or blue with an orange pronotum. It is found under the bark of beech, oak, or willow. It is rather rare.

\section{Genus Hylotrupes, Serv.}

Elytra flat, broad, and, like the pronotum, covered with scattered grey specks. Antennæ filiform and as long as the body in the males, but shorter in the females. The only British species is:

* H. bajulus, Linn. (Plate XVI., Fig. 6). This beetle is pitchyblack or brown, with a few lighter spots of thick hair in fresh specimens. It is common in old deal, in fittings, and in posts.

\section{Genus Tetropium, Kirby.}

Antennæ setiform, half as long as the body. Elytra broader than the pronotum. Femora much thickened. It is found on the trunks of trees.

T. luridum, Linn. (Plate XVI., Fig. 7). This species is covered with fine grey pubescence. The pronotum is rather shining. It is common in various parts of the Continent in the trunks of fir and pine trees. 




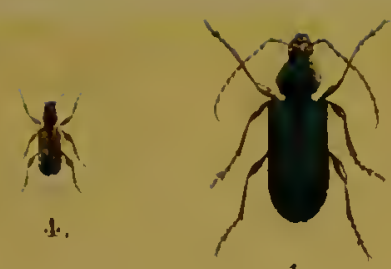

1. (a)

3.
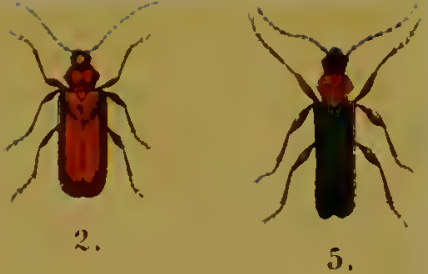

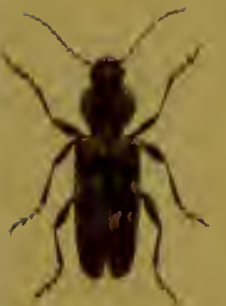

6.

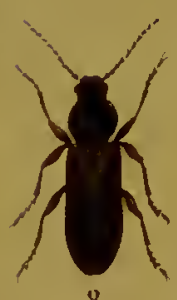

8.

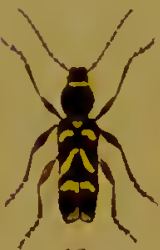

13.

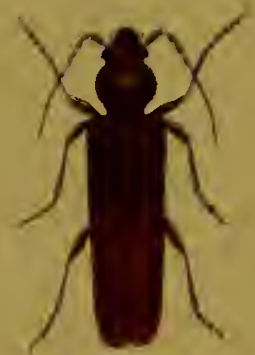

9

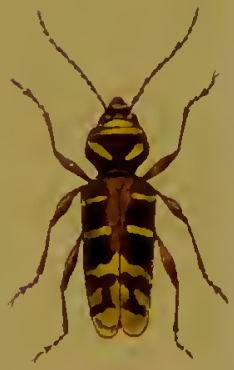

10.

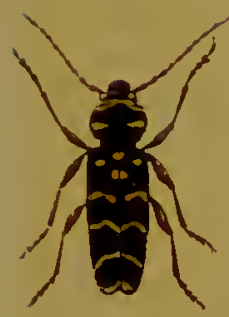

11.

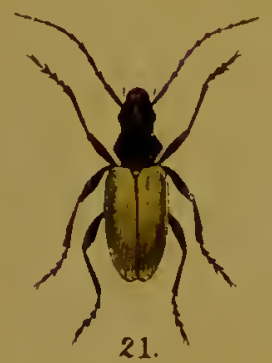

in

16.

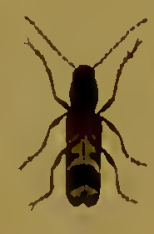

IT.
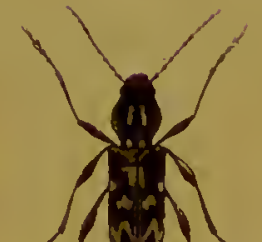

$1 \%$
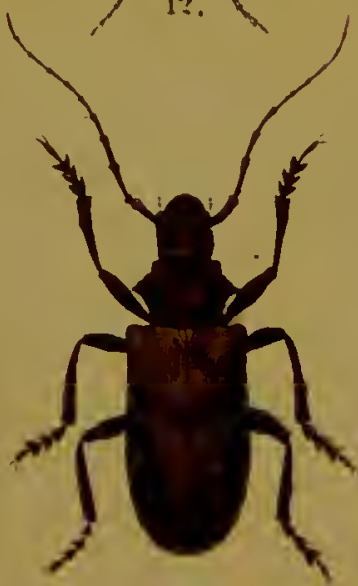

23.

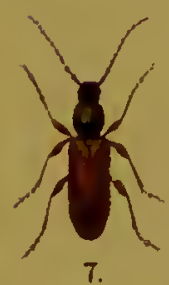

7.

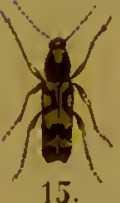

15.

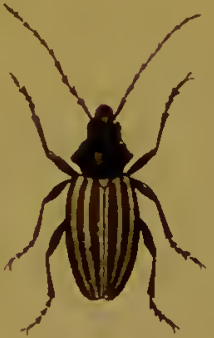

20.

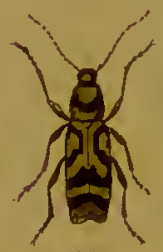

1t.

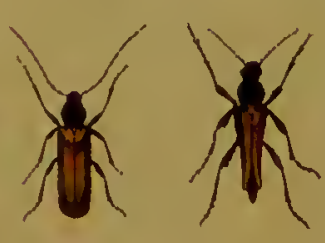

18.

19. 



\section{Genus Asemum, Eschsch.}

Pronotum rounded, rather narrower than the elytra, but not flattened, with only a few indistinct pits. The only British species is:

* A. striatum, Linn. (Plate XVI., Fig. 8). This is dull black, with three longitudinal striæ on the elytra, which are rarely brown. It is found in old fir and pine stumps in Scotland.

\section{Genus Criocephalds, Muls.}

Wing-cases only slightly broader than the pronotum, and nearly three times as long as the breadth of both. The females have a projecting ovipositor.

C. rusticus, Linn. (Plate XVI., Fig. 9). Brown, with two or more small pits on the pronotum. The wing-cases have three longitudinal strix. It is found in the roots of felled pine-trees in various parts of the Continent.

\section{Genus Clytus, Fabr.}

Pronotum elongated or rounded, and more or less globularly convex. Wing-cases generally as broad as the pronotum. Upper surface of the body pubescent. They live on flowers and on felled timber. The larve are found in wood.

C. detritus, Linn. (Plate XVI., Fig. 10). Elytra black or brown, with four or five yellow bands, the hinder ones more or less coalescing. It is found on oaks on the Continent.

${ }^{*}$ C. arcuatus, Limn. (Plate XVI., Fig. 11). Elytra with four or five narrow, curved, yellow bands, and a yellow patch on the suture. It is found on willows, oaks, and beech trees, and is very rare in Britain.

C. liciatus, Linn. (Plate XVI., Fig. 12). Wing-cases rounded at the extremity, with several whitish zigzag bands. 
It lives on oak, elm, lime, and poplar, and is a native of Central Europe.

* C. arietis, Linn. (Plate XVI., Fig. 13). Pronotum black, with only the front border yellow. Elytra with several curved and one straight yellow band. It is common on oak, beech, and rose-bushes.

C. verbasci, Fabr. (Plate XVI., Fig. 14, 15). This species is greenish-yellow, with two interrupted curved black bands on the elytra, and a straight one belind. It is found on flowers in Southern and in some parts of Central Europe.

C. plebejus, Fabr. (Plate XVI., Fig. 16). Black, with greyishwhite markings on the wing-cases. It is found on Spiroce throughout Southern Europe. The larva lives in birch, poplar, and aspen.

* C. mysticus, Linn. (Plate XVI., Fig. 17). Black, with the elytra red in front; then black and whitish at the extremity. It is found on may-blossom. The larva lives in old fruit trees and in alders.

Genus Avisarthron, Redt.

Elytra broader than the pronotum. Femora not clubbed. Claws with a tooth-like expansion at the base. The only species is :

A. barbipes, Schrank (Plate XVI., Fig. 18). Wing-cases reddish-brown. Pronotum black. This beetle is found in the mountains of Southern Europe and Switzerland.

\section{Genus Stexopterus, Oliv.}

Wing-cases broadest at the pronotum, with an awl-shaped narrowing behind. They are found on flowers.

S. rufus, Limn. (Plate XVI., Fig. 19). This species is black, with shaggy hair. The wing-cases are ycllowish-brown, with the base and extremity black. The base of the antemne and 
the legs are orange. It is common on flowers in Southern and the southern portions of Central Europe.

Genus Dorcadion, Dalm.

Body broad. Pronotum widest in the middle. Antenne rather stout, setiform, rarely longer than the body. They are found on roads and on walls, sitting usually on their hind legs.

D. quadrilineatum, Muls. (Plate XVI., Fig. 20). This is at mative of South France. It is a striped variety of

D. fuliginator, Linn. (Plate XVI., Fig. 21), which is black, with thick white pubescence on the wing-cases. It is found in Switzerland and in Southern Europe.

\section{Genus Lamia, Fabr.}

Winged. Elytra granulated, and twice as long as broad.

* L. textor, Linn. (Plate XVI., Fig. 22). Black, with close,. sessile, brown pubescence. It is found on old willows and poplars, but is rare in this country.

\section{Genus Morohammus, Meg.}

Wing-cases cylindrical in the females, attenuated behind in the males. They are mountain species.

* M. sutor, Linn. Black, with a metallic-brown gloss. The scutellum has a ycllowish pubescence, with a deep barc longitudinal line. It is found on felled pine-wood, and is very rare.

Genus Acaxthoderus, Scrv.

The third tarsal joint very long. Females provided with an ovipositor.

A. varius, Fabr. (Plate XVII., Fig. 1). This is a black species, covered with thick pubescence. It is found in the old trunks of beech and oak-trees, and sonctimes in timberyards on the Continent. 


\section{Genus Astrnosius, Redt.}

Elytra twice as long as broad. Antennæe setiform, twice as long as the body in the females, and three, four, or even five times as long as the body in the males. They live on felled timber.

* A. adilis, Linu. (Plate XVII., Fig. 2). Brown, with thick pubescence. Wing-cases narrowed towards the tip in the female. It is found on felled pine-trees and in timberyards.

A. atomarius, Fabr. (Plate XVII., Fig. 3). Black, with thick greyish-brown chequered pubescence. It is found on oaks and in wood-piles in the Northern and Central parts of the Continent.

\section{Genus Leiopus, Serv.}

Wing-cases nearly twice as long as broad. The last abdominal segment is rather more conically pointed in the males than in the females. They are found in timber-yards.

* L. nebulosus, Linn. (Plate XVII., Fig. 4). This species is black, with grey pubescence. The wing-cases have two pale yellowish bands. It is found on the trunks of old pines, firs, and willows.

\section{Genus Pogoxocherus, Meg.}

Pronotum with a pointed spine on the sides. Elytra with very projecting shoulders. Femora thickened at the end. They are found on dry brush-wood.

* P. fascicularis, Panz. (Plate XVII., Fig. 5). Brown, with grey and brownish pubescence. The elytra are banded with white, and have a small black elevation. It is found on pinetwigs. It is a rare species, sometimes met with in Scotland. 



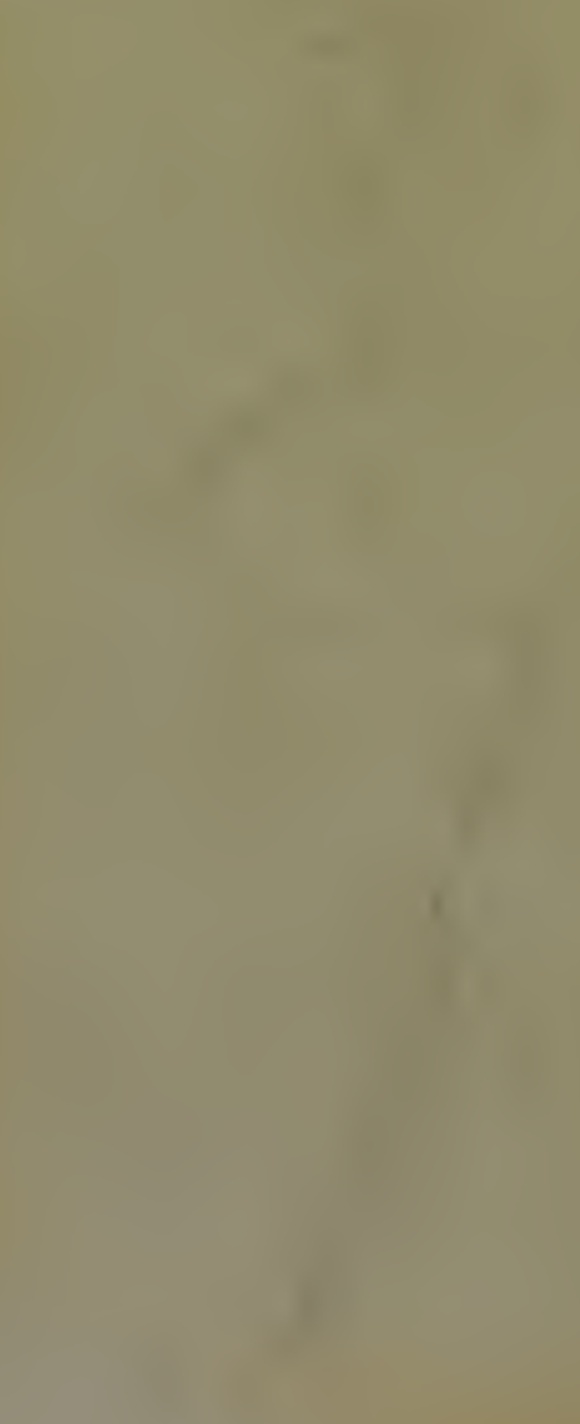

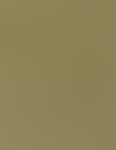
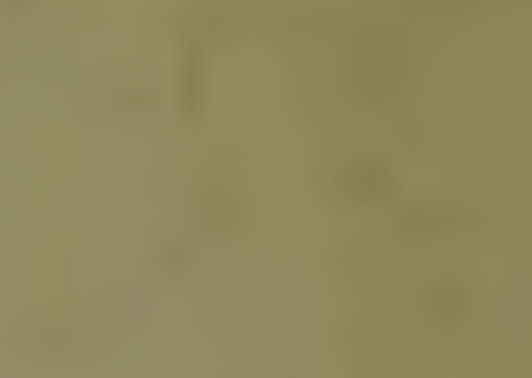
$y$

1.

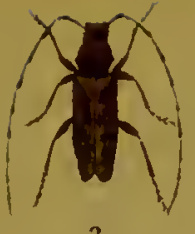

3.
(

1.
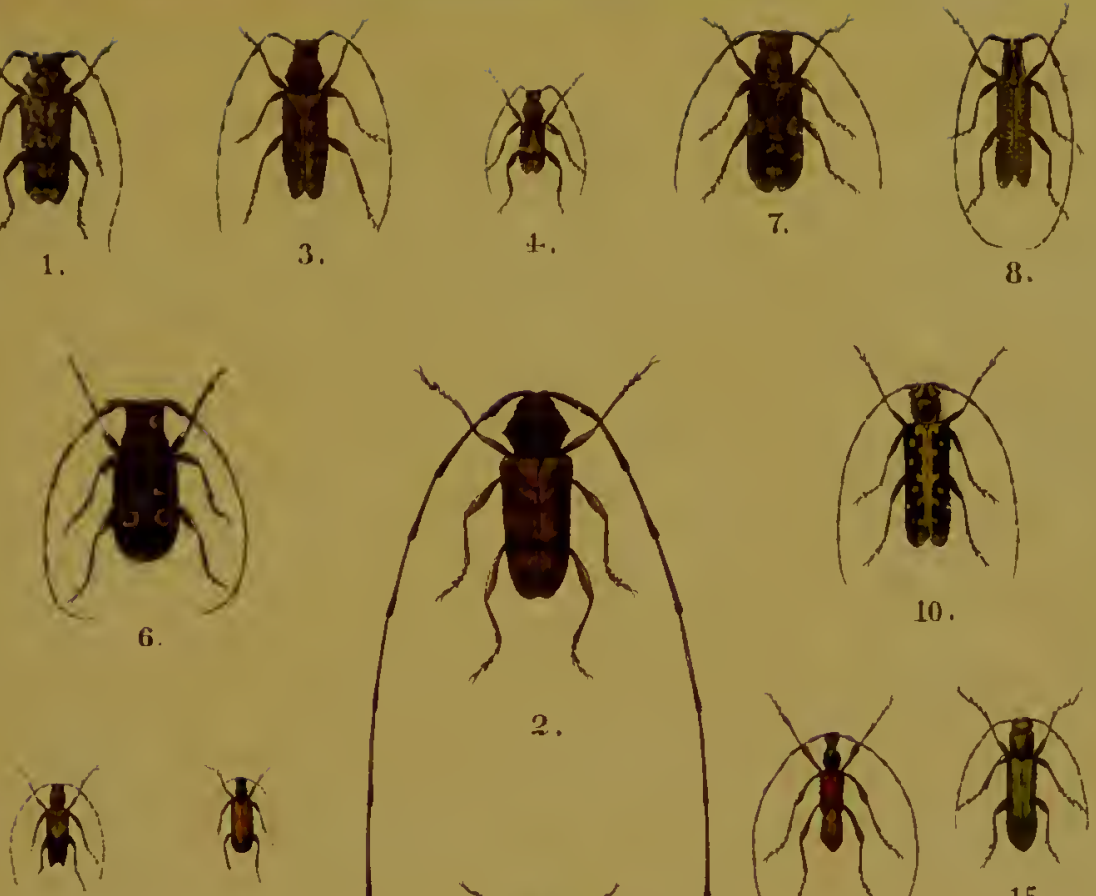

5.

12.

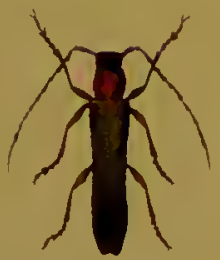

13.

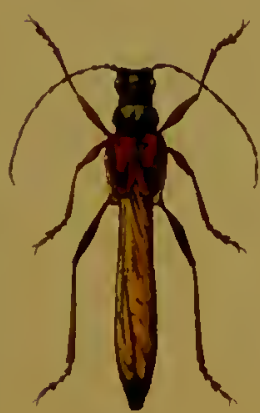

16.

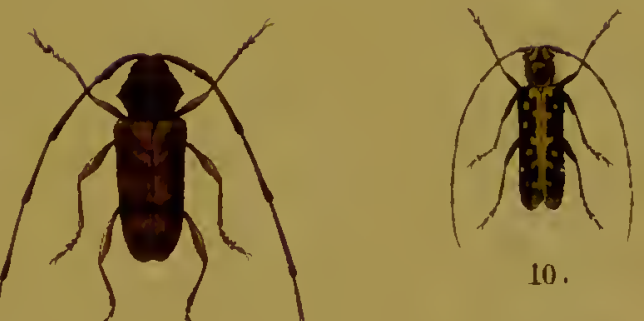

10.

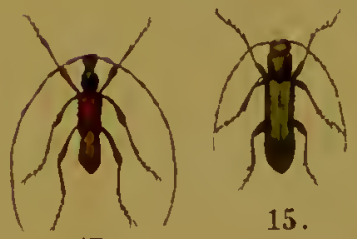

17.

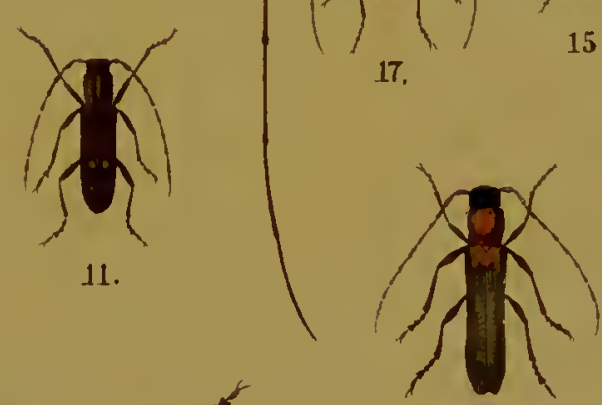

14.

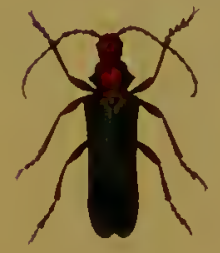

18. 



\section{Genus Mesosa, Serv.}

Wing-cases much broader than the pronotum. Antenne longer than the body, with long erect hair on the under surface. Femora somewhat thickened. They are generally found on pines.

Mr. curculionoides, Linn. (Plate XVII., Fig. 6). Black, with grey pubescence and galden-yellow spots. The pronotum and elytra have each four black pubescent spots upon them. It is found on the Continent.

* M. nubila, Oliv. (Plate XVII., Fig. 7). This species is clothed with reddish-brown and grey hair, and there is a whitish band on the elytra. It is found in the branches of oak and beech trees. It is rare in England.

\section{Genus Agapanthia, Serv.}

Elytra broader than the elongated pronotum. Head with a strongly convex top. They are found on flowers, especially on thistle-heads.

A. angusticollis, Gyll. (Plate XVII., Fig. 8). This beetle is black, with yellowish pubescence, and the first joint of the antennæ is clothed with thick yellow hair. It is common on the Continent on flowering thistles.

\section{Genus Saperda, Fabr.}

Wing-cases with the shoulders projecting, and either of uniform breadth or narrower behind. Antennæ as long as, or longer than, the body. They are found on flowers and bushes.

* S. carcharias, Linn. (Plate XVII., Fig. 9). This is covered with a grey or brownish-yellow pubescence. The males are distinctly attenuated behind. It lives on growing poplars and willows.

* S. scalaris, Linn. (Plate XVII., Fig. 10). Black, with yellow markings on the elytra, and a yellow suture. The 
larva lives in the shoots of cherry and walnut-trees, as well as in those of alder and elin. It is rare.

* S. populnea, Linn. (Plate XVII., Fig. 11). This species has yellowish-grey pubescence, with paler spots on the wing-cases. The larva lives in excrescences on the stems of the aspen.

\section{Genus Polyopsia, Muls. (Tetrops, Steph.)}

Elytra twice as long as the breadth of both. Eyes completely divided into two.

* P. procusta, Linn. (Plate XVII., Fig. 12). Elytra, except the extremity, jellowish-brown. Legs yellowish-brown, with blackish tarsi. It is found on apple and plum blossom, and the larva lives in dry twigs.

\section{Genus Oberea, Muls.}

Elongated, cylindrical beetles, without lateral projections on the pronotum. Wing-cases very narrow, obliquely truncated or rounded at the extremity. The larva live in the pith of bushes, and the beetles are found on the leaves.

* O. oculata, Linn. (Plate XVII., Fig. 13). This is an orange-coloured beetle, with the antennæ, wing-cases, and two spots on the pronotum black. It is found on willow and hazel. It is rare in Britain.

O. pupillata, Gyll. (Plate XVII., Fig. 14). This species resembles the preceding, but has the wing-cases yellow at the base. The larva lives in the stalks of bed-straw. It inhabits most parts of Central Europe.

\section{Genus Phytacia, Muls.}

Wing-cases generally narrowed behind, somewhat broader than the pronotum. Eyes strongly emarginate. Legs short. 'There is a large number of species, which live on various plants. 
P. virescens, Fabr. (Plate XVIT., Fig. 15). Upper surface covered with green or greyish-blue pubescence, with three paler lincs on the pronotum. The larva lives in the root of viper's bugloss (Echium).

Genus Necydalis Linn. (Molorchus, Fabr.)

Wing-cases scarcely longer than broad, and ouly slightly covering the projecting wings. Femora with a club-like expansion at the extremity. They are found on flowers and bushes.

M. salicis, Muls. (Plate XVII., Fig. 16). Black, with golden pubescence. Antennæ, legs, and ely tra reddish-ochreous. It is found on flowers, and the larva in willow, lime, and aspen. It is an inhabitant of Central Europe.

* N. minor, Linn. (Plate XVII., Fig. 17). Black and hairy, with brown elytra, antennæ, and legs. It is found on elderblossom. The larvæ live under the bark of fir trees, and their old burrows are sometimes seen on fellces. It is very rare.

\section{Genus Rhannusidm, Latr.}

Body rather cylindrical. Elytra broader than the pronotum. Antennæ filiform, scarcely half as long as the body. Femora of uniform thickness. The only European species is:

R. salicis, Fabr. (Plate XVII., Fig. 18). This is reddishbrown, with black elytra, with a blue or greenish shimmer. It is found on willows and poplars, and the larva lives in the wood of oak, beech, and elm. It is a native of Southern Europe.

\section{Genus Rhagium, Fabr.}

Elytra narrowed behind, flatly convex above. Hind femora nearly reaching the end of the elytra, and somewhat thickened. 'They are found on felled trees. 
R. mordax, Fabr. (Plate XVIII., Fig, 1). This beetle is thickly covered with yellow pubescence, with broad dull yellow transverse bands on the wing-cases. It is found on oak and alder, and the larva under the bark. It is an inhabitant of various parts of the Continent.

* R. inquisitor, Fabr. (Plate XVIII., Fig. 2). The transverse hands on the elytra are sharply-defined and orange-coloured, and interrupted at the suture. It is common on beech and vak, the larva living under the bark.

* R. indagator, Fabr. (Plate XVIII., Fig. 3). Brownishyellow, covered with white pubescence. The wing-cases have two indistinct transverse bands. It is found on firs and pines, the larva living under the bark. It is rare in England.

* R. Zifasciatum, Fabr. (Plate XVIII,, Fig. 4). Elytra not pubescent, black, with two oblique yellow marks. It is found on the trunks of pine-trees, and the larva under the bark.

\section{Genus Toxotus, Serv.}

Elytra twice as broad as the pronotum at the base, with projecting shoulders. Legs long and slender, with the femora somewhat thickened. They are found on flowering shrubs.

T. cursor, Linn. (Plate XVIII., Fig 5). The female is entirely black, but the male (noctis, Linn.) has red elytra, and reddish-ochreous antennæe and tibix. It is found in fir-woods, and the larva in stumps. It is an inhabitnut of several of the countries of Central Europe.

* T. meridionalis, Linn. (Plate XVIII., Fig. 6). Elytra considerably narrowed towards the extremity in the male, slightly narrowed in the female, which is either entirely reddishochreous, or only on the shoulders. The pronotum has an obtuse elevation on each side. It is common on flowers. 



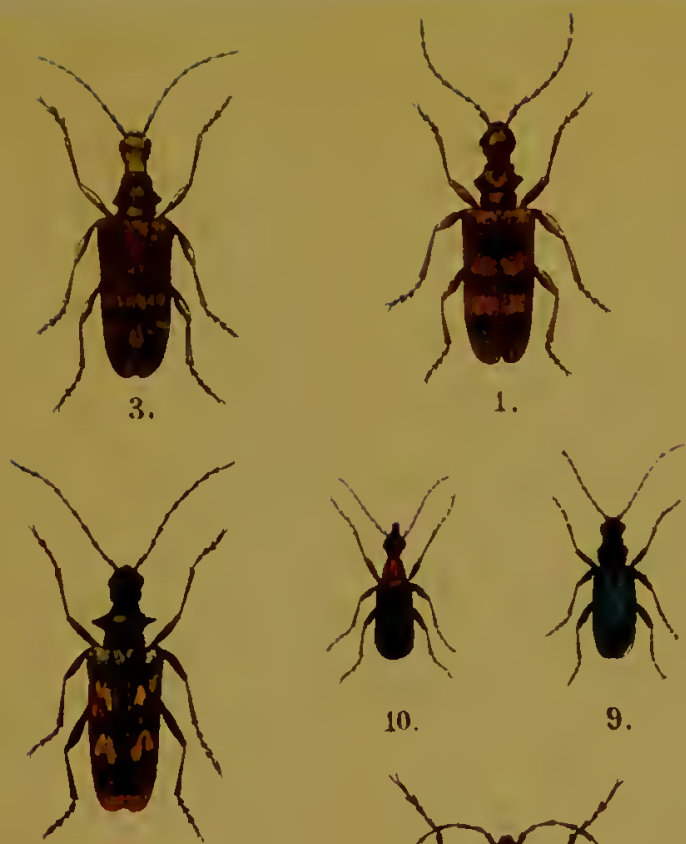

10.

9.
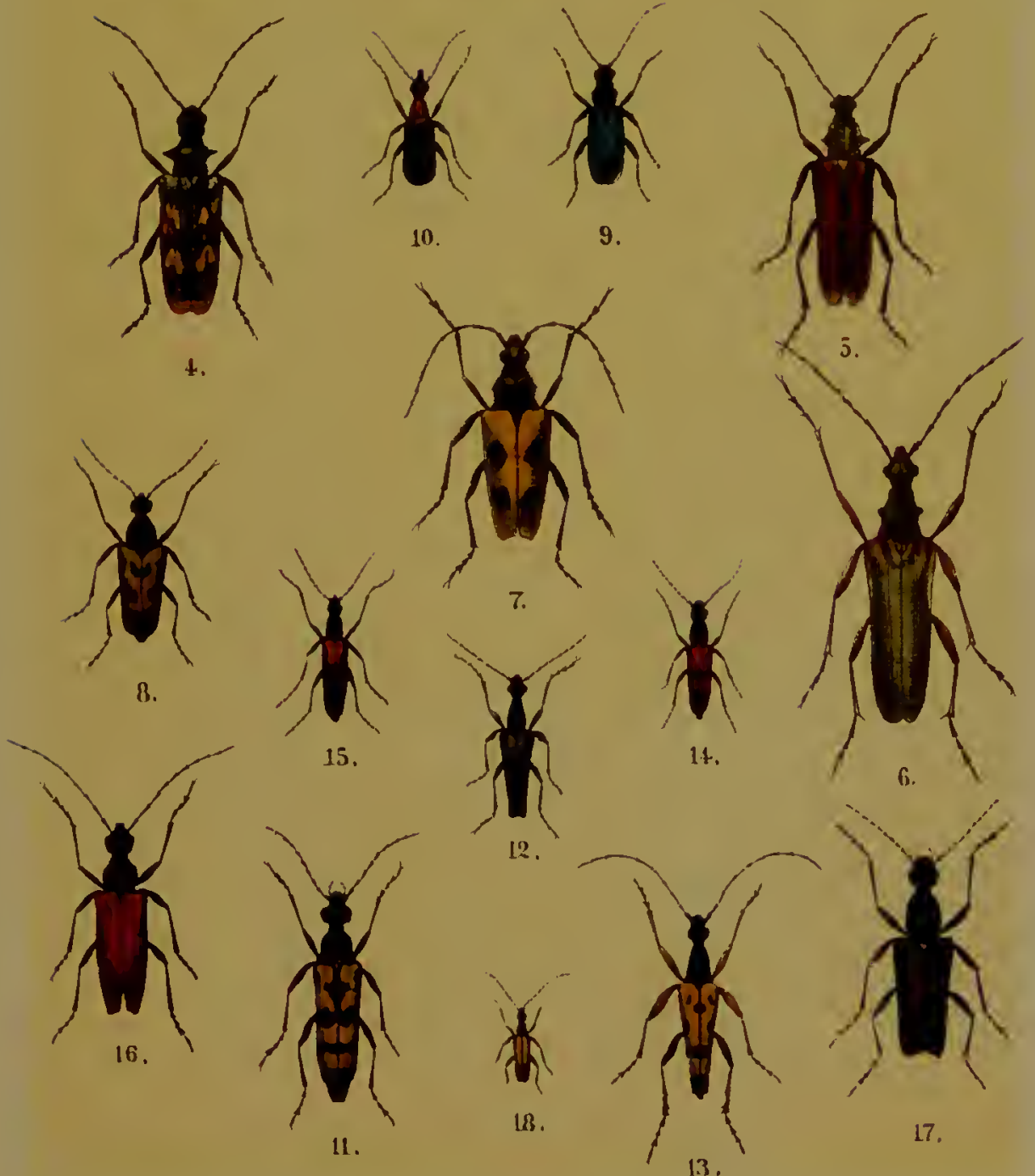

8.

15.

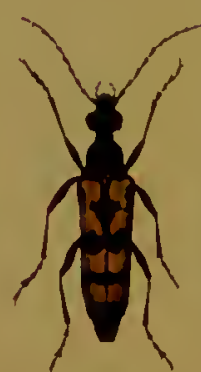

11.
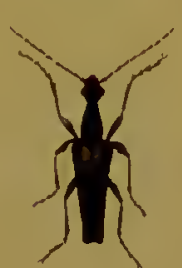

I9.

18.

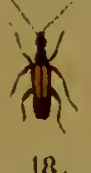

13.

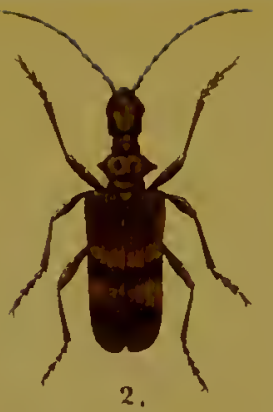



Genus Pachyta, Serv.

Wing-cases broad, very convex in front, with projecting shoulders much attenuated behind and rounded at the extrennities. They are found on Umbelliferce and on felled timber.

P. quadrimaculata, Linn. (Plate XVIII., Fig. 7). Elytra yellow, each with two black spots. It is found on flowers in various parts of the Continent.

* P. octomaculata, Schall. (cerambyciformis, Schrank), (Plate XVIII., Fig. 8). Wing-cases covered with grey pubescence, each with three or four black spots and a black extrenity. It is found on flowers and on felled timber. It is very local.

$P$. virginea, Linn. (Plate XVIII., Fig. 9). Wing-cases green, blue or violet. Abdomen, and generally the pronotum also, red. It is common in the mountains of Central Europe.

* P. collaris, Linn. (Plate XVIII., Fig. 10). Pronotum and abdomen red. Elytra violet, blackish-green or dark blue. It is most fond of Spiraca, upon which it is usually found, but is also common in hop gardens.

Genus Strangalia, Serv.

Wing-cases much narrowed behind in the males, less so in the females. Pronotum generally longer than broad. Legs slender. They frequent flowers.

* S. quadrifasciata, Linn. (Plate XVIII., Fig. 11). Wingcascs with three yellow interrupted bands, and tipped with black. They are found chiefly on elder-blossom.

S. atra, Fabr. (Plate XVIII., Fig. 12). This species is black, with fine grey pubescence, with a silky gloss beneath. It is found on the flowers of Umbelliferce, and inhabits Central Europe. 
* S. armata, Herbst (Plate XVIII., Fig. 13). Elytra yellow, with black bands. Hind tibire with two teeth in the male. Alsdomen black. In the female the tibix are simple, and the first three abdominal segments are yellow.

S. bifasciata, Schrank (Plate XVIII., Fig. 14). Elytra red, with a black tip and suture, the former being broadest; black in the female. It is found on flowers on the Continent.

* S. melanura, Linn. (Plate XVIII., Fig. 15). Black, witl reddish-brown elytra, tipped with black, and having a black suture, the former widest in the female. It is common on yarrow and ox-eye.

Genus Leptcra, Linn.

This genus resembles the last, but has the wing-cases more rounded at the tips. They are found on flowers.

L. testacea, Linn. (Plate XVIII., Fig. 16). The tibiæ and elytra are yellowish-brown in the male, they are red in the female, and so is the promotum. It is found on Spircoco, and the larva lives on fir-stumps. It is a Continental species.

* L. scutellata, Fabr. (Plate XVIII., Fig. 17). This is entirely black, with fine grey pubescence. The scutellum is covered with close white or yellowish hair. The larva lives in beech-stumps. It is rare in Britain.

\section{Genus Grammoptera, Serv.}

Wing-cases slightly narrowed and somewliat rounded at the end. Pronotum rounded in front, convex, with only small points at the hinder angles. They live on flowers.

* G. lcovis, Fabr. (Plate XVIII., Fig. 18). Black, with yellowish-brown elytra, tipped with blackish, and having a blackish suture. Antennæ pitchy-brown, with the first joint rusty-red. It is found on flowers, and is widely distributed. 


\section{FAMILY XLV. BRUCHID尼.}

Body generally rounded, with the head ending in a kind of proboscis. Wing-cases somewhat shortened, and consequently not entirely covering the abdomen. They live in seeds, and used to be classed with the weevils, but are now separated, because they have no groove for the antennæ, which are straight.

\section{Genus Bruchus, Linn.}

Small beetles, with eleven joints to the antennæ, which are inserted into an emargination of the eyes, and are thickened externally. They are found in the seeds of leguminous plants.

* E. pisi, Linn. (Plate XIX., Fig. 1). This species is black, with whitish-grey hair, and having the first four joints of the antennæ, the tibix, and tarsi orange. The larva is found in pea-pods, and so are dead specimens of the beetle occasionally. It is cosmopolitan.

* B. rufimanus, Schoenh. (Plate XIX., Fig. 2). This species resembles the last, but has the front femora orange. The larva is found in beans. It is generally distributed throughout the British Isles.

\section{FAMILY XLVI. CHRYSOMELID蚱.}

Short, compressed, and generally very convex beetles of small size, with different kinds of antennæ, which are rarely more than half as long as the body. They all live on low plants or bushes, and some of them are destructive to crops.

\section{Genus Orsodacna, Latr.}

Wing-cases rather cylindrical. Pronotum narrow. Antennæ filiform, and situated in front of the eyes. The head, together with the round prominent eyes, is as broad as the pronotum. They live on flowers. 
* O. cerasi, Fabr. (Plate XIX., Fig. 3). This is a variable insect, which may be pale reddish-yellow or black, with the pronotum yellow or entirely black. It is found on appleblossom and flowering birch, white-thorn, \&c. It is rare.

\section{Genus Donacia, Fabr.}

Wing-cases much broader than the pronotum, rather flat, with obtuse projecting shoulders. The lind femora are longer and generally thicker than the others. They live on waterplants.

* D. crassipes, Fabr. (Plate XIX., Figs. 4 and 9). Metallicgreen or bluish, with the base of the antennæ and the legs reddish. The hind femora of the male have two teeth. It is not uncommon on water-lilies.

* D. sagittarice, Fabr. (Plate XIX., Fig. 5). Liglit green, with a golden shine, with fine pubescence. This species closely resembles $* D$. lemna, Fabr., which has, however, a longitudinal purple stripe on the elytra. It lives on water-plants and on reeds.

* D. discolor, Panz. (Plate XIX., Fig. 6). Pale green, blue or blue-black; the front angle of the pronotum projecting as $a$ small pointed protuberance. It is found in damp meadows and on aquatic plants.

* D. menyanthidis, Fabr. (Plate XIX., Fig. 7). Goldengreen, with silvery-white pubescence. The antennæ and legs are reddish. The hind femora reach as far as the end of the elytra. The beetles live gregariously on the leaves of reeds and iris.

D. tomentosa, Ahrens. (Plate XIX., Fig. 8). This is bronze colour or greenish, with the base of each joint of the antennæ and the legs blackish. It is found in Germany on Typha, Poa, and Sparganium. 


o

$\int_{3}$

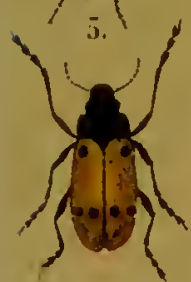

16.
- a k o

3.

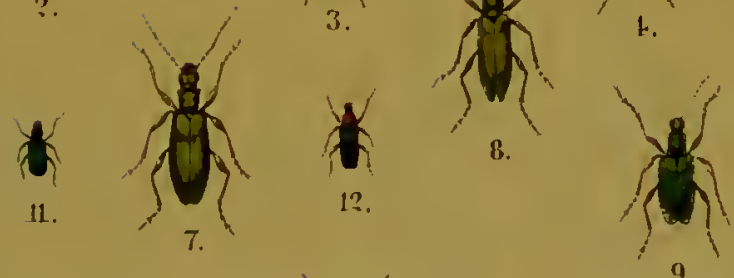

6.

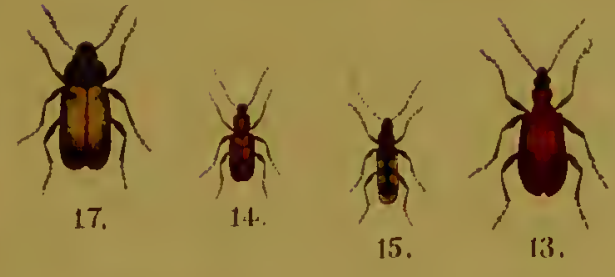

15.

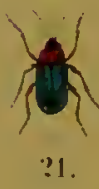

$? 1$.

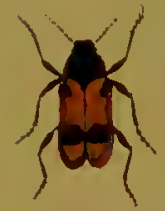

20.

,

13.

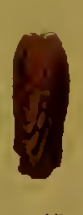

19.

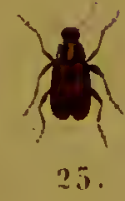

25.

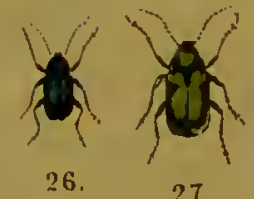

27.

(स) की की

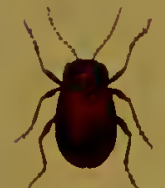

39.

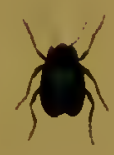

40.
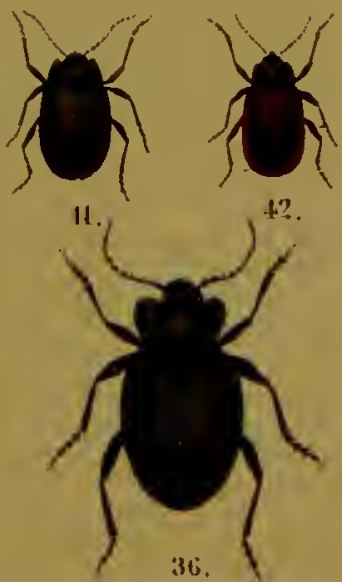

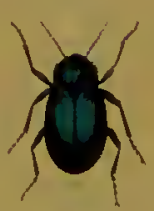

43 .

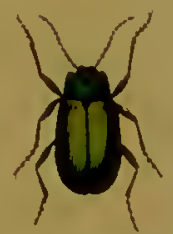

44

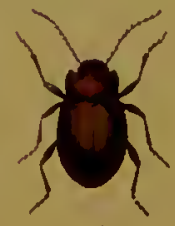

38.

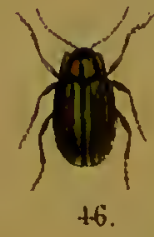

$+6$. 

* D. (Hamonia) equiseti, Fabr. Yellow, with a black head, antenux, and sternum. The wing-cases have a row of punctures. It is found on water-plants, and spends the larval state in the root. It is very rare.

Genus Zeugophora, Kunze.

Body cylindrical. Pronotum long and narrow. Head broader than long, with prominent eyes. Legs short and thick. They live on trees, and the larvæ mine the leaves.

* Z. flavicollis, Marsh (Plate XIX., Fig. 10). Black, with an orange pronotum, prosternum, and legs. It lives on poplars, and the larvæ mine the leaves, which become black. It is very rare.

\section{Genus Lema, Fabr.}

Wing-cases expanded in front and somewliat constricted. Pronotum much narrower than the wing-cases. Claws close together, and either coalescing or separated at the base. They live on various plants, and are able to produce a kind of chirping by rubbing the wing-cases.

* L. cyanella, Linn. (Plate XIX., Fig. 11). Blue or bluishgreen, with black antennæ and tarsi.

* L. melanopa, Linn. (Plate XIX., Fig. 12). Blue, with the pronotum, femora, and tibiæ red. Both this and the preceding species live on grass and corn. The larvæ have a slimy coating, and live on the blades of these plants. It is common, and widely distributed.

* L. (Crioceris) merdigera, Linn. (Plate XIX., Fïg. 13). Black, with orange elytra and pronotum. It is found on lilies. The larva, which has a slimy black covering, lives on the leaves. It is very rare.

* L. (Crioceris) duodecimpunctata, Limn. (Plate XIX., Fig. 14). Elytra orange, with six black spots. It lives on asparagus, and the larva in the seeds. This species is also very rare. 
* L. (Crioceris) asparagi, Lim. (Plate XIX., Fig. 15). Wingcases yellowish, with six black spots and a black cross. Both beetle and larva are found on asparagus.

\section{Genus Clythra, Laich.}

Cylindrical bectles, with the head retracted and generally with a vertical front. Pronotum as broad as the elytra, usually somcwhat expanded. They are found in meadows and on low plants, and the larve live in hairy, leathery cases, with only the head and legs free, and drag the cases after them.

C. longipes, Fabr. (Plate XIX., Fig. 16). This is biack, with the elytra palc yellow, with thrce black spots. In the male the front lcgs are very long. It is a South European species.

C. longimana, Lim. (Plate XIX., Fig. 17). Elytra paie yellow, with a small spot on the shoulders. Antennæ violet, reddish at the base. The head is very large in the male, and the front lcgs are very long. It is common in many parts of Central Europe.

*C. quadripunctata, Linn. (Plate XIX., Fig. 18). Shining orange-colour, with two black spots on each of the elytra. It is found on willow, lime, and aspen. The larva lives on low plants in a case. (Fig. 19.)

C. locviuscula, Ratzb. (Plate XIX., Fig. 20). This species is also orange, with a smooth shining pronotum. There are two black spots on the elytra, the hinder of which is very large. It is a native of Southern Furope.

C. cyanea, Limn. (Plate XIX., Fig. 21). Pronotum and legs orange. Elytra shining blue, or bluish-green. It frequents damp meadows and ditches, and is found in many parts of the Continent. 
Genus Eumolpus, Kugel.

Pronotum very convex, broader than long, and expanded in the middle. Wing-cases nearly quadrangular. They are found on water-plants.

E. obscurus, Linn. (Plate XIX., Fig. 22). Black, slightly shining, with fine grey pubescence. It is found in ditches on willow-herb, and is common in most parts of the Continent.

\section{Genus Cryptocephalus, Geoff.}

Cylindrical, with the head retracted. Pronotum usually as large as the wing-cases, which are rounded. There are pits on the last segment of the abdomen in the females. These beetles live on low plants and shrubs, and the larvæ have a case.

* C. coryli, Linn. (Plate XIX., Fig. 23). Black, with the wing-cases red and rather coarsely punctured. Two dots on the front of the head, and the basal joints of the antennæ are yellow. The pronotum is black in the male, but red in the female. It lives on hazel, alder, and willow, but is rare.

C. cordiger, Linn. (Plate XIX., Fig. 24). Elytra cherry-red, with two black spots on each, and a fine black border. The pronotum is marked with yellow. It is found on willow, hazel, and alder in many parts of the Continent.

C. octopunctatus, Scop. (Plate XIX., Fig. 25). Elytra red, each with two variable black spots, and a raised lateral border. It is common in many places on the Continent.

C. violaceus, Fabr. (Plate XIX., Fig. 26). Blue or greenish, finely pubescent beneath. It is common in Southern Europe on birch and willow.

* C. sericeus, Linn. (Plate XIX., Fig. 27). Golden-green, violet or reddish-purple, with two slight depressions on the pronotum. It is common on flowers. 
C. lobatus, Linn. (Plate XIX., Fig. 28). Black, with a blue pronotum and elytra. The legs and the portion of the head in front of the antennæ are yellow. It is found on birch, willow, and alder in various parts of the Continent.

C. variegatus, Fabr. (Plate XIX., Fig. 29). Elytra entirely yellow, with scattered punctures and a small black mark on each shoulder angle. It is found on birch-trees in South Central Europe.

* C. morcei, Linn. (Plate XIX., Fig. 30). Black, with yellow lateral spots, and the extremity of the wing-cases yellow. It is not uncommon, especially on St. John's wort.

C. Alavipes, Fabr. (Plate XIX., Fig. 31). Black, with dark blue elytra. The legs and the front and lateral borders are yellow in the male: It is found on the Continent on hazel, birch, and willow.

C. marginatus, Fabr. (Plate XIX., Fig. 32). The male is blue-black and the female yellow, with a blue-black suture and margins. It is a South European species, living on birch and oak.

* C. bipunctatus, Linn. (Plate XIX., Fig. 33). Black, with a large red spot at the end of each of the elytra. The variety * bipustulatus, Fabr. (Fig. 34), is black, with two red spots at the hind angles of the elytra. The beetle is found on bushes.

C. (Pachybrachys) hicroglyphicus, Fabr. (Plate XIX., Fig. 35). This is a black species, with the head, antennæ, pronotum, elytra, and legs yellow and black. It is found in Southern and some parts of South Central Europe.

Genus Thmarcha, Latr.

Body rounded, very convex. Wingless. Pronotum bordered, with a raised ridge. They live in grass and under stones, and exude a red liquid from their joints if touched. 
* T. tcnebricosa, Fabr. (Plate XIX., Fig. 36). Black, with the pronotum widest before the middle. The beetle, and its stout dark green larva, are common on bushes in early spring. Length, $11-18 \mathrm{~mm}$.

* T. coriaria, Fabr. (Plate XIX., Fig. 37). Black, very shining, with the pronotum widest in the middle. Antennæ and legs reddish-brown. It is common on heaths and commons.

T. metallica, Fabr. (Plate XIX., Fig. 38). Bronze-coloured. It is found in the mountains of the Austrian Empire.

Genus Chrysomela, Linn. (Golden Apple Beetles).

Body oval or elongated, very convex, generally winged. The second joint of the antennæ is narrower than the first and third. They live on low plants and bushes, often in such numbers as to be very destructive.

* C. staphylea, Linn. (Plate XIX., Fig. 39). This is an oval, shining, metallic, yellowish-brown beetle, with irregularly striated wing-cases. It is common in the spring under stones.

* C. varians, Fabr. (Plate XIX., Fig. 40). Dark blue, greenish-violet, dark green or bronzy, with a coppery or golden shine. It is found on St. John's wort, \&c.

* C. goettingensis, Linn. (Plate XIX., Fig. 41). This is violet, with rusty-yellow antennæ, palpi, and tarsi. It is found in spring under stones, in sandy and chalky places. Length, $7-9 \mathrm{~mm}$.

* C. marginata, Linn. (Plate XIX., Fig. 42). Bronzy-brown, with the base of the antennæ and a narrow border on the elytra orange. It is found in sandy places, but is rare. Length, $5-7 \mathrm{~mm}$.

C. violacea, Panz. (Plate XIX., Fig. 43). Blue or bluishgreen, with scatlered punctures on the wing-cases. It is found in ditches, on species of Mentha, on the Continent. 
*C. graminis, Linn. (Plate XIX., Fig. 44). Golden-green, with the base of the antennæ orauge. It is particularly fond of common tansy.

* C. fastuosa, Linn. (Plate XIX., Fig. 45). This is flatly convex, golden-green, with the base of the antennæ light yellow. It is found on nettle and similar plants.

* C. cerealis, Linn. (Plate XIX., Fig. 46). Metallic-green or red, with fiery red and purple stripes. It is found under stones in the spring, and later on grass, thistles, \&c. It is very local.

* C. lamina, Fabr. (Plate XX., Fig. 1). Shining olive-green, with the base of the antennæ reddisl. The elytra are covered with fine scattered punctures. It is found on poplars.

C. (Oreina) tristis, Fabr. (Plate XX., Fig. 2). Elongated, blue or greenish, with frequently a greenish shimmer on the elytra. It lives on coltsfoot, ragwort, \&c. It is found in the Alps and Pyrenees.

C. (Oreina) speciosa, Pauz. (gloriosa, Fabr.), (Plate XX., Fig. 3). This is also green or blue, and very difficult to distinguish from the last species. It is also a mountain insect, and is found in the Alps and Pyrenees.

* C. (Lina) cenea, Linn. (Plate XX., Fig. 4). Blue or green, and occasionally black. The lateral border of the pronotum is not raised. The base of the antennæ and border of the extremity of the abdomen is orange. It is common on birch and alder.

C. (Lina) vigintipunctata, Scop. (Plate XX., Fig. 5). Bronzy-green, with the lateral borders of the pronotum, the base of the antennæ, and the elytra straw-colour, the last being marked with twenty black spots. It is found on willows on the Continent.

C. (Lina) lapponica, Linn. (Plate XX., Fig. 6). Blue-black or bluish-green. The wing-cases are orange, with three 



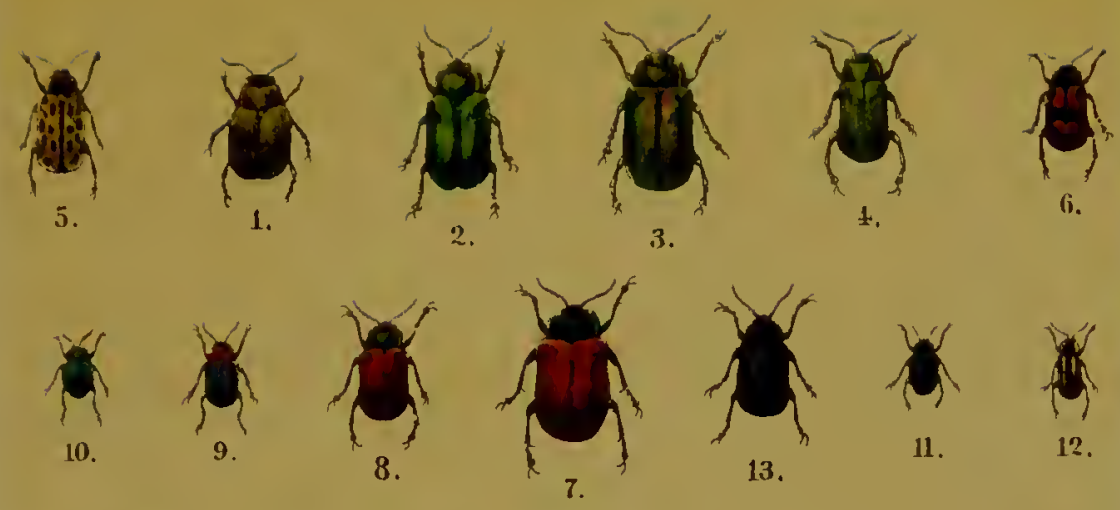

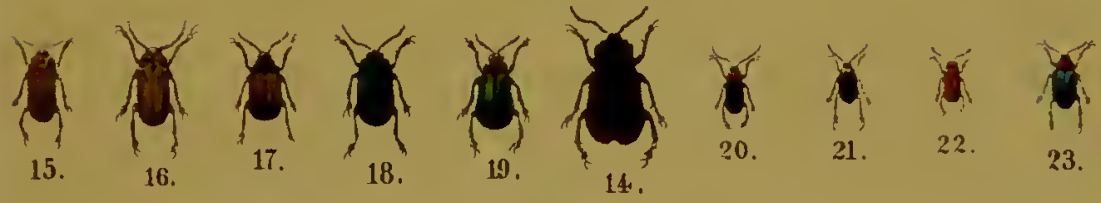
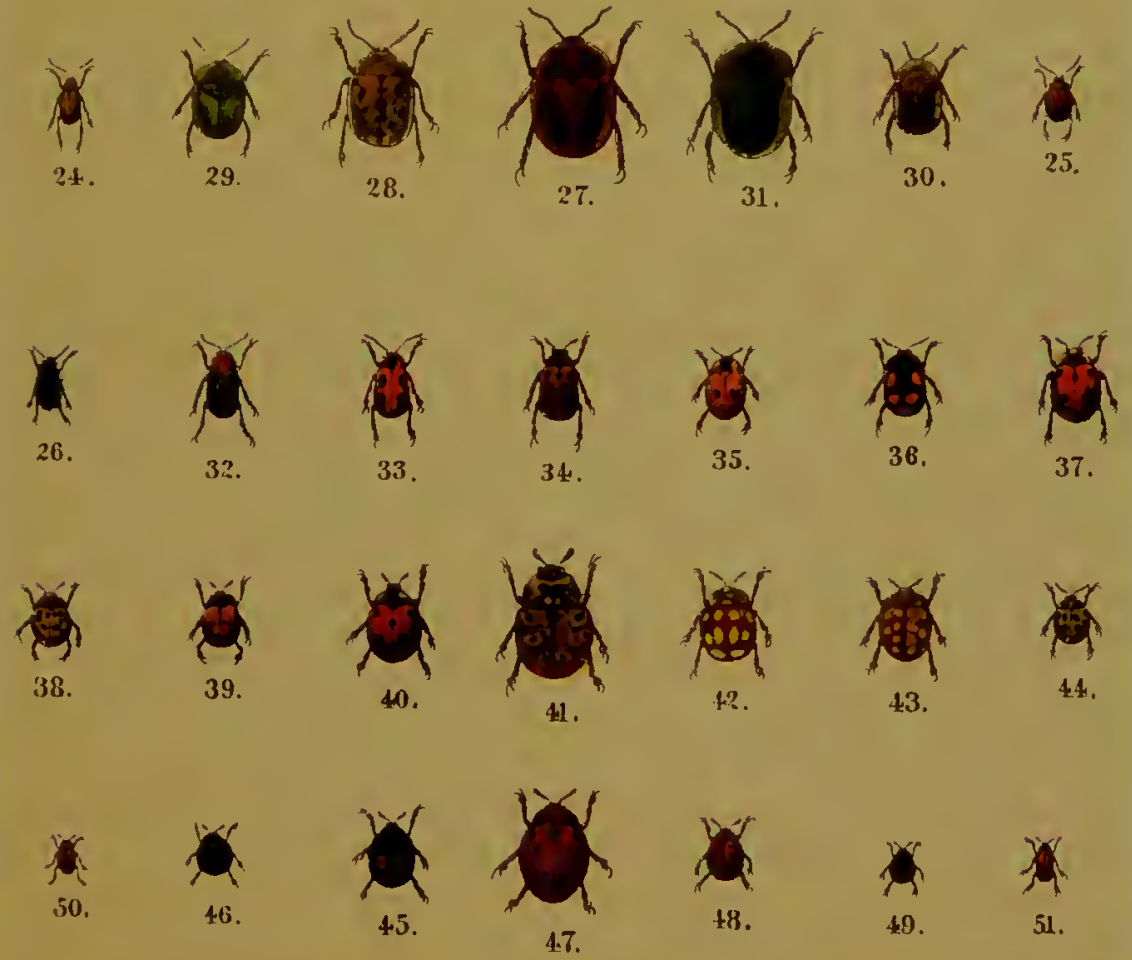

irregular bluish-green transverse bands. . It is found in North-Eastern Europe, on willows.

* C. (Lina) populi, Linn. (Plate XX., Fig. 7). Blue-black, with brick-red elytra, tipped with black. The sides of the pronotum are slightly raised at the edges behind. It is common on poplars.

* C. (Lina) tremula, Fabr. (Plate XX., Fig. 8). This species closely resembles the foregoing, but is smaller, and has the edges of the pronotum more raised. It is found on poplars.

* C. (Gastrophysa) polygoni, Linn. (Plate XX., Fig. 9). Bhuish-green, with the base of the antennæ, the pronotum, femora, and tip of the abdomen, red. It is common on knotgrass (Polygonum).

* C. (Plagiodera) armoracice, Linn. (Plate XX., Fig. 10). Blue, green, violet, or coppery, with the base of the antennæ reddish-brown. It is met with on willows.

* C. (Phratora) vulgatissima, Linn. (Plate XX., Fig. 11). Metallic-bluish-green, greenish, or purple, with the base of the antennæ and border of the abdomen reddish. 'It is common on willows.

* C. (Helodes) phellandrii, Linn. (Plate XX., Fig. 12). This is an elongated species, with the lateral nnargins of the pronotum and elytra, and a straight longitudinal band on the latter, yellow. It is common on Phellandrium, in the stalks of which the larva lives.

Genus Adimonia, Laich.

Wing-cases broader than the pronotum, expanded and bulging behind. The third joint of the antemne is longer than the fourth. The females are inuch larger than the males, and have a projecting abdomcm. They live on various plants. 
* A. tanaceti, Linn. (Plate XX., Fig. 13). Generally entirely black, the elytra coarsely and deeply punctured. It is found on wild tansy, and is most common on the south coast in chalky districts.

A. rustica, Schall. (Plate XX., Fig. 14). Wing-cases lighter brown. Scutellum longitudinally depressed. It is found in various parts of the Continent on grass plots.

\section{- Genus Galeruca, Fabr.}

* G. nymphoce, Fabr. (Plate XX., Fig. 15). Brownishyellow, with a blackish border to the wing-cascs. Ścutellum with a large pit on each side. It is found on water-plants.

* G. viburni, Payk. (Plate XX., Fig. 16). Brown, shagreened. There is a black spot on the front of the head and a central line, and the lateral borders of the pronotum are also blackish. It is found on flowering shrubs.

* G. lincola, Fabr. (Plate XX., Fig. 17). Yellowish-brown, with the scutellum black. It is found on willow and alder.

Genus Agelastica, Redt.

Head and eyes nearly as broad as the middle of the pronotum. Wing-cases broader than the pronotim at the base, expanded and bulging behind. They are found on bushes.

* A. alni, Linn. (Plate XX., Fig. 1S). Violet or blue, with black antennæ, scutellum, and tarsi. The under surface is blue-black. Both the beetle and its black larva are found on alder. It is very rare.

* A. halensis, Linn. (Plate XX., Fig. 19). Wing-cases green or bluish-green. Pronotuin orange. It is common, especially on bed-straw. 
Genus LUPERUS, Geoffr.

Pronotum bordered on the sides. Head produced, and together with the eyes nearly as broad as the pronotum. Elytra broader than the pronotum. Femora not thickened. They live on trees and bushes.

* L. flavipes, Linn. (Plate XX., Fig. 20). Black, with the first joints of the antennæ, the pronotum, and legs orange. It is found on fruit-trees, and is especially fond of the leaves of pear-trees. It is generally distributed through the British Isles.

Gemus Haltica, Illig. (Flea Beetles).

Pronotum much broader than long. Wing-cases usually rather broader than the pronotum. Hind femora thickened. This is a large genus of very small hopping beetles, which live upon low plants and trees, and are often destructive to field produce.

* H. (Crepidodera) versicolor, Kutsch. (aurata, Marsh), (Plate XX., Fig. 21). Blue or green, with a golden glitter and a crimson pronotum. The legs are orange, with the exception of the femora. It is found on willows and poplars.

H. (Crepidodera) impressa, Fabr. (Plate XX., Fig. 22). This is reddish-ochreous, with numerous punctures. It is a South European species.

* H. (Podagrica) fuscicornis, Linn. (Plate XX., Fig. 23). Wing-cases blue, with the head, pronotum, antennæ, and legs orange. It is common on mallow.

* H. (Phyllotreta) nemorum, Linn. This species is one of the commonest of the black and yellow flea-beetles. It is often very destructive to turnips, cabbages, and other garden produce. 
*H. (Longitarsus) verbasci, I’anz. (Plate XX., Fig. 24). Pale brownish-yellow, with the suture and the hind femora frequently pitchy-brown. It is loeal, but eommon where it oceurs, on mullein.

* H. (Sphceroderma) testccea, T.unz. (1'late XX., Fig. 25). This species is hemispherical and orauge-colourcd. It is common on low plauts.

Genus Hispa, Linn.

Head produeed. Pronotum lroader than long, and like the wing-eases eovered with long spines.

H. atrc, Linn. (Plate XX., Fig. 26). Dull blaek, with a long spine at the end of the first joint of the antennie, and a short one on the seeond joint. It is found on grass growing in sandy plaees. It is common in many parts of the Continent.

\section{Genus Cassida, Linn.}

Head hidden under the pronotum. Elytra rounded at the extremity, much broader than the abdomen, with a raised lateral margin. They live on low plants. Most of these species have a beautiful golden or silvery gloss, whieh disappears soon after death.

C. austriaea, Fabr. (Plate XX., Fig. 27). Rusty-brown, with blaek spots; duriug life with a golden shine. Both larva and beetle are found on meadow-sage. It is a South European species.

* C. murrcea, Linn. (Plate XX., Fig. 28). Rounded oval, reddish-brown above, blaek beneath. The legs are also blaek. The beetle and larva are both found on mint and Inula. It is searee.

* C. vibex, Linn. (rubiginosa, Illig.), (Plate XX., Fig. 29). Green, with a triangular reddish-brown mark at the base of the elytra. It is found most frequently on thistles. 
* C. nebulosa, Linn. (Plate XX., Fig. 30). Rusty-browı, indistinctly tinged with yellowish-green, and irregularly spottcil with black. It attacks beet-root and clover, but is rare.

* C. equestris, Fabr. (viridis, Linn.), (Plate XX., Fig. 31). Green above, black beneath. The elytra are thickly punctured and finely granulated. It lives on low plants, more particularly on the Labiatce.

\section{FAMILY XLVII. EROTYLIDÆ.}

Antennæ with eleven, rarely with only ten joints, club-shaped. Legs widely separated. Front coxæe globular, and inserted into articular depressions. Tarsi with four or five joints, the fourth being frequently very small and enclosed within the third.

Genus Triplax, Fabr.

Antennæ with the three terminal joints enlarged, forming a club. Body elongated, or elongated oval. They live in fungi.

* T. russica, Linn. (Plate XX., Fig. 32). Orange, witl black antennæ, scutellum, and elytra. It is found on fungi growing on apple-trees.

Sub-family ENDomychids.

Antennæ attached either between or in front of the eyes. Tarsi four-jointed, with the third very small and hidden in ill excavation in the second. They are found under the bark of old trees.

Genus Exdourchus, Panz.

Prosternum with a projection separating the middle coxic. The only British species is:

* E. coccineus, Linn. (Plate XX., Fig. 33). Deep red, with two black spots on each wing-case, and one on the middle of the pronotum. It is found under the decaying bark of trees. 


\section{SECTION IV. TRIMERA.}

(Beetles with three visible joints to the tarsi.)

\section{FAMILY XLVIII. COCCINELLIDE (Lady Birds).}

Body heinispherical. Antennæ with from nine to eleven joints, gradually thickened or clubbed, and inserted in front of the eyes. Tarsi apparently three-jointed, the third joint heing hidden in the second. The beetles and their active linva live on Aphides.

Genus Hippodania, Muls.

Elongated, with the upper surface of the body bare. The antenne are eleven-jointed, and attached at the front margin of the eyes. The legs are rather slender, with the fernora somewhat overlapping the border of the body.

* H. tredecimpunctata, Linn., the Thirteen-spot Lady Bird (Plate XX., Fig. 34). Wing-cases red, with thirteen very variable spots. It is very local, and generally rare.

Genus Coccinelua, Linn.

Body generally hemispherical. The last joint of the antennie is scarcely narrower at the base than the extremity of the last but one.

* C. bipunctata, Linn., the Two-spot Lady Bird. (Plate XX., Figs. 35, 39). This species is red, with black spots, but is very variable, and the black colour sometimes predominates, as in Fig. 36 . It is very common.

* C. deccmpunctata, Linn., the Ten-spot Lady Bird 166 
(Plate XX., Fig. 37). Red, with about ten black spots, morc or less. It is common, and generilly distributed.

* C. impustulata, Linn. (Plate XX., Fig. 38). Yellow, with about eight more or less connected black spots on the elytril, and seven on the pronotum.

* C. septcmpunctata, Linn., the Seven-spot Lady Bird (Plate XX., Fig. 40). Red, with some white on the scutellum. Each of the wing-cases has three spots, and there is another, commun to both wing-cases, on the suture. This and the Two-spot are the commonest species.

* C. (Halyzia) ocellata, Linn. (Plate XX., Fig. 41). Very convex, orange, with numerous black spots generally ringed with yellow.

* C. (Halyzia) decemguttata, Linn. (Plate XX., Fig. 42). Orange-colour, with the sides of the pronotum and five lar,re spots on each of the wing-cases whitish.

* C. (Halyzia) scdecimpunctata, Linn., the Sixteen-spot Lady Bird (Plate XX., Fig. 43). Reddish-yellow, with a broad whitish border to the elytra, and eight whitish spots on each.

* C. (Micraspis) duodecimguttata, Linn., the Twelve-spot Lady Bird. (Plate XX., Fig. 44). Yellow, with black spots on the pronotum. Wing-cases with nine black spots and a black suture.

Genus Chilocorus, Leach.

Body not pubescent. Elytra-much broader than the pronotum at the base.

* C. renipustulatus, Scriba. (Plate XX., Fig. 45). Black, with a transverse oval red spot on each wing-case, and a red abdomen.

* C. (Exochomus) quadripustulatus, Linn. (P'late XX., Fig. 46). Black, with four red spots. The colour of the pronotum and of the legs varies. It is locally common. 


\section{Genus EpIlachna, Chevr.}

Body convex, pubescent above. Antennæ eleven-jointed, with the basal joint not covered by the clypeus. They are found on various plants.

E. undecimmaculata, Fabr. (Plate XX., Fig. 47). Very envex, orange, with eleven black spots. It is found in Firuice and Germany, on bryony.

* E. globosa, Schneid. (Plate XX., Fig. 48). Rusty-red, with very variable black spots. It is common on the coast, and frequents lucerne.

Genus Scymnus, Kugel.

Elytra at the base only slightly, if at all, broader than the pronotum. Pronotum narrowed in front.

* S. frontalis, Fabr. (Plate XX., Fig. 49). Black, with grey pubescence. Elytra with one or two red spots. It is common at the roots of grass, \&c.

\section{Genus Rhizobius, Steph.}

Body elongated oval, pubescent. The last tarsal joint is nearly pointed. The elytra are irregularly punctured. The only l3ritish species is:

* R. litura, Fabr. (Plate XX., Fig. 50). This beetle is reidish-ochreous, finely pubescent. The elytra have brown lines, zigzag beneath. It is very common throughout England, in moss and at the roots of grass.

\section{Genus Coccidola, Kugelm.}

Body elongated oval. The last joint of the antennæe is olliquely truncated. Elytra with rows of striæ. They live on marsh-plants.

* C. rufa, Herbst (Plate XX., Fig. 51). Orange, with the 
head, pronotum, and legs generally somewhat lighter. The sternum and the first two abdominal segments are black. It is very common in marshy places.

\section{FAMILY XLIX. PSELAPHID巫.}

Elytra short. Antennæe eleven-jointed, clubbed. Tarsi three-jointed. They are very small beetles, which are found anong moss, under stones, and in ants' nests, and are easily recognised by the characters of the antennæ.

Genus Pselaphus, Herbst.

* $P$. heisei, Herbst. Length, $1 \mathrm{~mm}$. It is rusty-red, with the pronotum much longer than broad, and is found under stones, in moss, \&c., and is generally distributed.

Genus Claviger, Preyssl.

* C. testacerus, Panz. Length, $1 \frac{1}{2}-2 \mathrm{~mm}$. It is reddish-ochreous, with the antennæ as long as the head, and is both wingless and eyeless. It is found in chalky places on the south coast, in the nests of small yellow ants. 



\section{INDEX OF GENERA, FAMILIES, ETC.}

\begin{tabular}{|c|c|c|c|c|c|c|c|c|}
\hline & & & PAGE & & & & & PAGE \\
\hline Abax & • & - & - 24 & Apate & - & • & - & 113 \\
\hline Acanthoderus & • & - & - 145 & Aphodins & - & - & . & 74 \\
\hline Acilius & - & - & 33 & Apion & - & • & - & 135 \\
\hline Adelocera & - & - & 95 & Apoderus & - & • & $\cdot$ & 136 \\
\hline Adimonia & - & - & - 161 & Aromia & - & • & - & 141 \\
\hline Agabus & - & - & 31 & Asemunı & - & • & - & 143 \\
\hline Agrapanthia & - & - & . 147 & Astynomus & - & • & $\cdot$ & 146 \\
\hline Agelastica & - & - & - 162 & Atopa & - & • & - & 102 \\
\hline Agrilus & - & - & 92 & Attagenus & - & • & - & 64 \\
\hline Agriotes & - & - & . 100 & Attelabus & - & . & - & 136 \\
\hline Alcochara & - & - & 40 & & & & 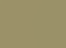 & \\
\hline Alophus & - & - & - 127 & Balaninus & - & $\bullet$ & - & 132 \\
\hline Amara & - & - & 25 & Baridins & - & - & - & 134 \\
\hline Ampedus & • & • & 96 & Baris & - & • & $\cdot$ & 134 \\
\hline Anchomenus & 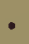 & • & 26 & Barynatus & - & $\cdot$ & - & 123. \\
\hline Anchyloclieira & $\bullet$ & - & 90 & Bembidiun! & • & $\cdot$ & - & 28 \\
\hline Anisarthron & $\bullet$ & - & - 144 & Berosus & • & • & - & 36. \\
\hline Anisodactylus & - & • & 25 & Blaps & - & $\bullet$ & $\cdot$ & 114 \\
\hline Anisoplia & ${ }^{\circ}$ & $e^{\circ}$ & 83 & Bledius & - & $\bullet$ & $\cdot$ & 47 \\
\hline Anisotoma & $\bullet$ & • & 54 & Bletlisa & • & $\bullet$ & - & 14 \\
\hline Anobium & $\cdot$ & - & - 113 & Bolitolius & • & $\cdot$ & · & 41 \\
\hline Anomala & $\bullet$ & ${ }^{\circ}$ & 84 & Bolitophagus & • & $\cdot$ & • & 115 \\
\hline Antliaxia & 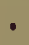 & $\theta^{\circ}$ & 91 & Bostrychidie & • & $\bullet$ & - & 137 \\
\hline Antlobium & - & $\bullet$ & 50 & Bostrychus & $\bullet$ & $\bullet$ & 113, & 137 \\
\hline Anthoconius & • & • & . 107 & Brachinus & • & • & - & 20 \\
\hline Anthonomus & $\cdot$ & ' & - 132 & Bracliyderes & $\bullet$ & • & - & 124 \\
\hline Antlophagrus & $\bullet$ & • & 49 & Brontes & • & • & • & 60 \\
\hline Anthous & 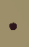 & • & 98 & Bruchide' & $\cdot$ & 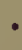 & . & 153 \\
\hline Anthrenus & • & - & 65 & Bruchus & • & $\cdot$ & - & 153 \\
\hline Anthribidac & $\cdot$ & ' & - 138 & Buprestida & • & $\bullet$ & • & 89 \\
\hline Anthribus & • & • & - 139 & Buprestis & - & $\cdot$ & - & 90 \\
\hline
\end{tabular}


Byrrhidi

Byrrhus

Byturus

Bytinn

Calandra

Callidium

Callistus

Calosoma

Campylus

Cantharidæe

Cantharis

Carabidre

Carabus

Cardiophorus

Cassida

Catops

Ceranibycidre

Ceeranzbyx

Cercyon

Cetonia

Cetonini

Ceuthorlyynchus

Clialcophora

Chilocorus

Chlrenius

Chlorophaulus

Chrysobothris

Chryscmela

Chrysomelidie

Cicindela

Cicindelidie

Cionus

Cistela

Claviger

Cleonus

Clcridie

Clcrus

Clivina

Clythra

Clytus

Coccidula

Coccinella

Coccincllid:e

134

141

27

18

. 101

- 120

104,120

14

16

96

164

50

139

- 140

38

85

- 85

- 134

89

- 167

. 22

- 125

91

- 159

153

- 13

13

- 133

- 116

- 169

- 127

- 108

. 109

- 19

- 156

- 143

- 168

- 166

- 166
Colydiid.e :

Colydium

Copris

Coprophini

Coræbus

Corymbitcs

Corynetes

Cossonus

Creophilus

Crepidodera

Crioccphalus

Crioccris

Cryptoccphalus

Cryptophagidre

Cryptophagus

Cryptorhynchus

Cucujide

Curculionidæe

Cychranus

Cychrus

Cyclonotum

Cynatoliterus

Cymindis

Cyllion

Dascillidx

Dascillıs

Dasytes

Dendroctonus

Dermestes

Dermestidx

Dis\}reris

Dicerca

Ditoma

Donacia

Dorcadion

Dorcus

Dryocetes

Dynastini

Dytiscide

Dytiscus

Elaphrus

Elater
PAGF:

59

60

143

- 155

157

61

61

133

60

122

58

15

37

30

21

. 103

102

102

107

137

64

63

115

89

59

154

145

70

138

84

28

32

15

96 
INDEX OF GENERA, FAMILIES, ETC.

\begin{tabular}{|c|c|c|c|c|c|c|c|}
\hline & & & PACE & & & & PAGE \\
\hline Elateride & - & . & 94 & Homaloplia & • & • & 79 \\
\hline Elmis & - & . & 67 & Homalota & . & • & 39 \\
\hline Emus & • & . & 42 & Hoplia & - & - & 78 \\
\hline Endomychidie & . & • & - 165 & Hydaticus & . & . & 33 \\
\hline Endomychus & . & • & . 165 & Hydræua & . & . & 37 \\
\hline Epilachna & • & . & . 168 & Hydrobius & . & . & 35 \\
\hline Epuræa & • & . & 57 & Hydrophilide & . & . & 34 \\
\hline Ergatcs & . & - & . 139 & Hydrophilus & . & . & 35 \\
\hline Erirhinus & - & - & . 131 & Hy'droporis & . & . & 29 \\
\hline Eros & - & - & . 103 & Hydrous & - & . & 35 \\
\hline Erotylidre & - & - & . 165 & Hylastes & . & . & . 137 \\
\hline Eucuemidx & • & - & 93 & Hylecœtus & - & . & . 110 \\
\hline Eumolpus & . & - & . 157 & Hylobius & . & $\cdot$ & . 130 \\
\hline Exochomus & - & $\cdot$ & . 167 & Hylotrupes & . & $\cdot$ & . 142 \\
\hline & & & & Hylnrgus & - & $\cdot$ & . 137 \\
\hline Galeruca & - & - & . 162 & Hypera & . & $\cdot$ & . 127 \\
\hline Gastrophysa & - & . & . 161 & Hyphydrus & . & - & 29 \\
\hline Geotrupes & - & - & . 76 & & & & \\
\hline Gibbium & • & - & . 112 & Ilybius & . & - & 31 \\
\hline Gnorimus & $\cdot$ & . & 87 & Ips & . & - & 58 \\
\hline Grammoptera & - & . & . 152 & & & & \\
\hline Grypidius & - & - & . 131 & Laccobits & - & . & 36,73 \\
\hline Gynmetron & - & - & . 133 & Laccophilus & . & . & . 30 \\
\hline Gyrinidæ & - & - & . 34 & Lacon & . & . & . 95 \\
\hline Gyrinus & . & - & 34 & Lagria & - & . & . 118 \\
\hline & & & & Lagriidæe & - & . & . 118 \\
\hline Hæmonia & . & - & . 155 & Lamcllicornes & . & . & . 70 \\
\hline Haliplns & - & - & 29 & Lamia & $\cdot$ & - & . 145 \\
\hline Haltica & - & - & . 163 & Lampra & - & . & 90 \\
\hline Halyzia & . & • & . 167 & Lampyris & - & . & . 104 \\
\hline Harpalus & - & . & - 27 & Larinns & $\cdot$ & - & - 129 \\
\hline Hedobia & - & . & . 111 & Lathridiidæ & . & . & 61 \\
\hline Helodes & . & - & 103,161 & Lathridius & . & - & 62 \\
\hline Helophorus & - & - & . 36 & Latlırobiunı & . & - & 45 \\
\hline Helops & - & - & . 115 & Lebia & . & . & - 20 \\
\hline Heteroceridre & . & • & - 68 & Leiopus & . & - & - 146 \\
\hline Heterocerus & - & - & 68 & Leistotrophus & . & - & - 42 \\
\hline Hcteromera & . & - & . 114 & Lcistus & . & . & - 19 \\
\hline IIippodania & . & - & . 166 & Lema & . & . & . 155 \\
\hline Hispa & • & . & . 164 & Leptura & . & . & - 152 \\
\hline Hister & . & . & . $\quad 55$ & Lepyins & . & . & . 130 \\
\hline Histcridle & . & . & . 55 & Limonius & . & . & . $\quad 97$ \\
\hline Homalisus & - & . & . 103 & Liua & - & . & . 160 \\
\hline
\end{tabular}


Liophlilocus

Lixus

Loinechursa

Lougicornia

Longitarsns

Lorieera

Lueanidie

Lueanus

Ludius

Luperus.

Lymexyłon

Lymexylonidæ

Lytta

\section{Magdalinus}

Malaehius

Ialacodermida

Malthinus

Malthodes

Melandrya

Mclandryidie

Mrelanoturs

Meligethes

Meloe

Melolontlıa

Melolonthini

Mlesosa

Metallites

Metœens

Mieraspis

Minyops

Molopes

Molorelius

Monoliammus

Mordella

Morlellidæ

Mycetophagidæ

Myeetophagus

Myrmedonia

Nacerdes

Nehria

Necrodes
Neeroplitus

Neerophorus

Niptus

Nitidulidre

Notiophilus

Oberca

Ochthebins

Ocypus

Odontrous

Erdeneridx

Omalium

Omasens

Omophron

Oniticellus

Onthophagus

Opatium

Opiliss

Orchesia

Orehestes

Oreetoehilus

Oreina

Orsodaena

Oryctes

Osmoderms

Otiorlıynelıus

Oxyporus

Oxytelus

Oxythyrea

Pachybrachys

Pacliyta

Paderus

Panagxus

Parnidre

Parnus

Peltis

Pentamera

Phalaerus

Phalacridx

Philhydrus

Philontlius

Pliratora
PaOK

51

112

15

148

37

43.

76

120.

49

22

14

73

72

114

108

117

132

34

160.

153.

84

87

122

47

48

85

158

151

46.

21

67

67

59.

13

56

56

36

- 44

- 161 


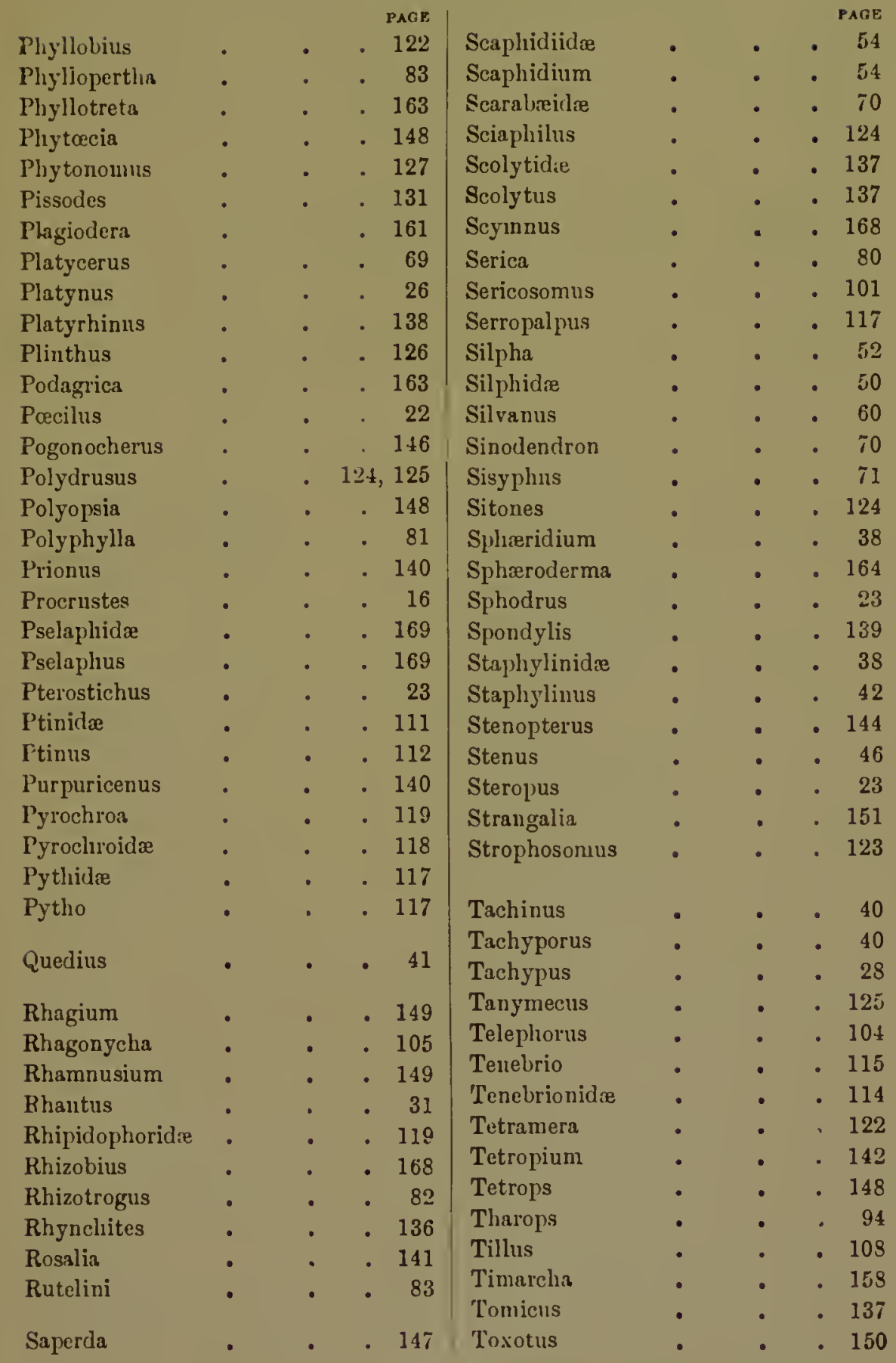




\section{BEETLES.}

Tracliys

Trichius

Trichodes

Trimera

Triplax

Trixagus

Trogosita

Trogositidæ

Trogus

Tropideres

Tropinota

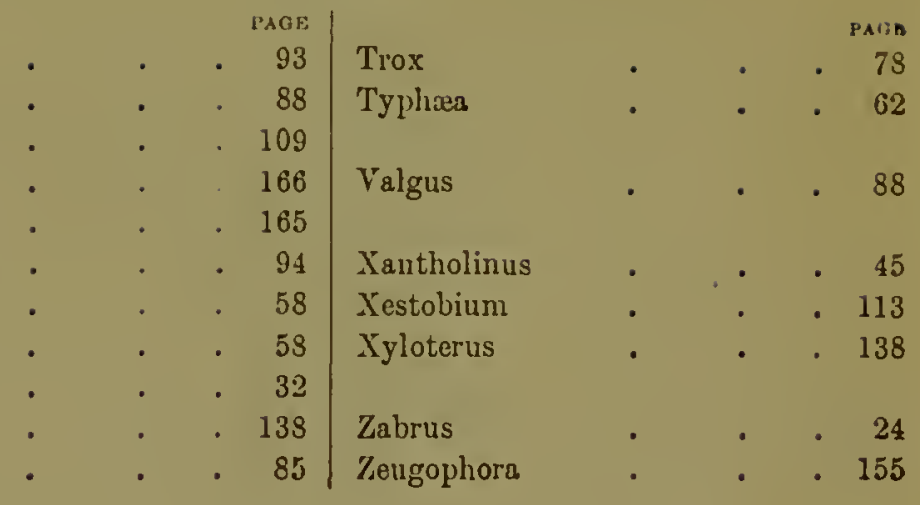




\section{LIST OF AUTHORS,}

\section{IVITII ABBREVIATIONS.}

Alirens.

Audersch.

Bergstraesser (Bergst.).

Bjerkander (Bjerkand.).

Bonclli (Bon.).

Brahm.

Cederhieln (Cedorh.). Chevrolat (Chevr.).

Clairville (Clairv.).

Creutzer (Crentz.).

Curtis.

Dalman (Dalm.).

Dawson (Daws.).

De Geer.

Dejean (Dcj.).

Duftschmidt (Duft.).

Dumeril (Dum.).

Erichson (Ericlis.).

Eschscholtz (Eschsch.).

Fabricius (Fabr.).

Faldermann (Falderm.).

Fallén (Fall.).

Fiselier (Fisch.).

Forster (Forst.).

Foureroy (Fourc.).
Frnehlich (Froehl.).

Fuessly (Fuessl.).

Geoffroy (Geoffr.).

Germar (Germ.).

Gerstaccker (Gerst.).

Gravenhorst (Grav.).

Gyllenhal (Gyll.).

Harris.

Heer.

Hellenius (Hellon.).

Hellwig (Hellw.).

Herlist.

Herselell (Hersch.).

Hoflmaun (Hoff.).

Illiger (Illig.).

Kiesenwetter (Kicsenw.).

Iírby.

Iilug.

Kugelann (Kugcl.).

Kunze.

Kutschera (Ǩntsch.).

Laichartig (Laich.).

Laporte.

Iatreille (Latr.)

Leacli. 
Lepelletier (Lep.).

Linneus (Linn.).

Ljungh.

Mae Leny.

Mannerlıeim (Mannerh.).

Marsham (Marsh.).

Megerle (Mleg.).

Muiller (Müll.).

Mulsant (Muls.).

Newman.

Olivier (Oliv.).

Panzer (Panz.).

Paykull (Payk.).

Perty.

Prcyssler (Preyssi.).

Ratzeburg (Ratzel.).
Redtenbacher (Redt.).

Rossi (Ross.).

Samouelle.

Seliaeffer.

Schaller (Selıall.).

Sehmidt.

Schneider (Sehneid.).

Sehoenherr (Selıoenlı, or Sehönh.)

Schrank.

Scopo!i (Seop.).

Seriba (Serib.).

Serville (Serv.).

Solier (Sol.).

Spinola (Spin.).

Stephens (Stepl.).

Sturm.

Sulzer (Sulz.).

Weler.

Ziegler (Ziegl.).

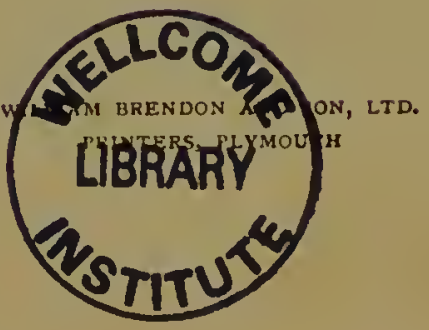


米 



$$
\text { . }
$$

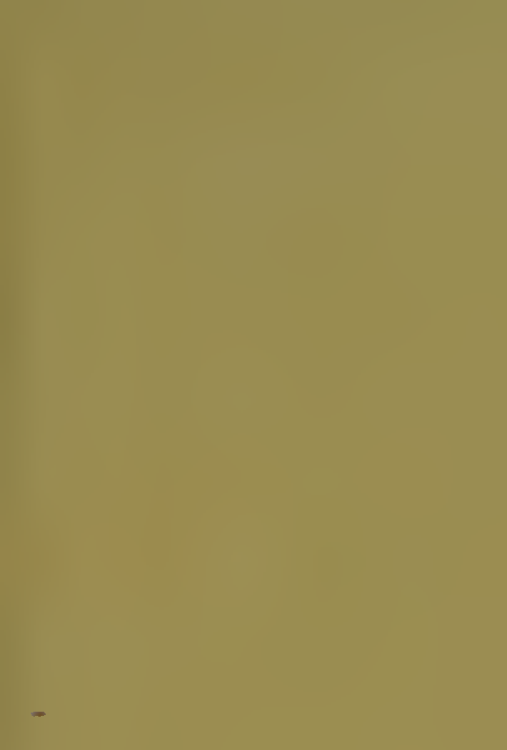

$$
\text { - }
$$


